\title{
BUILDING POLITICAL CAPITAL: \\ THE POLITICS OF 'NEED' IN THE FEDERAL GOVERNMENT'S MUNICIPAL INFRASTRUCTURE PROGRAMS, 1993-2006
}

\author{
by \\ Robert N. Hilton, B.A. \\ A thesis submitted to the Faculty of \\ Graduate Studies and Research in partial fulfillment \\ of the requirements for the degree of \\ Master of Arts \\ in Canadian Studies
}

Carleton University

Ottawa, Ontario

April 2007

Copyright 2007, Robert N. Hilton 


$\begin{array}{ll}\begin{array}{l}\text { Library and } \\ \text { Archives Canada }\end{array} & \begin{array}{l}\text { Bibliothèque et } \\ \text { Archives Canada }\end{array} \\ \begin{array}{l}\text { Published Heritage } \\ \text { Branch }\end{array} & \begin{array}{l}\text { Direction du } \\ \text { Patrimoine de l'édition }\end{array} \\ \begin{array}{l}\text { 395 Wellington Street } \\ \text { Ottawa ON K1A ON4 } \\ \text { Canada }\end{array} & \begin{array}{l}\text { 395, rue Wellington } \\ \text { Ottawa ON K1A 0N4 } \\ \text { Canada }\end{array}\end{array}$

Yourfile Votre référence

ISBN: 978-0-494-26946-6

Ourfile Notre référence

ISBN: 978-0-494-26946-6

NOTICE:

The author has granted a nonexclusive license allowing Library and Archives Canada to reproduce, publish, archive, preserve, conserve, communicate to the public by telecommunication or on the Internet, loan, distribute and sell theses worldwide, for commercial or noncommercial purposes, in microform, paper, electronic and/or any other formats.

The author retains copyright ownership and moral rights in this thesis. Neither the thesis nor substantial extracts from it may be printed or otherwise reproduced without the author's permission.
AVIS:

L'auteur a accordé une licence non exclusive permettant à la Bibliothèque et Archives Canada de reproduire, publier, archiver, sauvegarder, conserver, transmettre au public par télécommunication ou par l'Internet, prêter, distribuer et vendre des thèses partout dans le monde, à des fins commerciales ou autres, sur support microforme, papier, électronique et/ou autres formats.

L'auteur conserve la propriété du droit d'auteur et des droits moraux qui protège cette thèse. $\mathrm{Ni}$ la thèse ni des extraits substantiels de celle-ci ne doivent être imprimés ou autrement reproduits sans son autorisation.
In compliance with the Canadian

Privacy Act some supporting forms may have been removed from this thesis.

While these forms may be included in the document page count, their removal does not represent any loss of content from the thesis.
Conformément à la loi canadienne sur la protection de la vie privée, quelques formulaires secondaires ont été enlevés de cette thèse.

Bien que ces formulaires aient inclus dans la pagination, il n'y aura aucun contenu manquant. 


\begin{abstract}
Although the federal government has no responsibility under the Constitution for municipal infrastructure, since 1993 successive governments were convinced of the need to provide billions of dollars to support the construction of thousands of municipal capital projects. This thesis examines the public policy underpinning the federal government's decisions in this regard. While some literature has analyzed the results of the initial municipal infrastructure program launched more than a decade ago, there has not yet been a comprehensive examination of the federal programs in toto.

Given the demands from municipal governments for more funding for infrastructure, an examination of the federal policy rationale is overdue. The thesis argues that there are alternatives to transfers from senior levels of government to municipal governments that offer better results both in terms of generating adequate sources of revenue for infrastructure and providing clearer accountability for the expenditures of these revenues.
\end{abstract}




\section{ACKNOWLEDGEMENTS}

I would like to express my sincerest gratitude to my two thesis supervisors, Richard Nimijean and Chris Stoney, for their ongoing encouragement during my M.A. program. I would also like to thank the other members of the thesis defence examination committee, Susan Phillips, Director of the School of Public Policy and Administration, and Pauline Rankin, Director of the School of Canadian Studies.

As well, my thanks go to Mike Bazuk, a senior manager with the Public Service Human Resources Management Agency. His ongoing encouragement of my studies is a testament to his belief in the fundamental value of post-graduate research and the benefits it accords the Public Service of Canada.

I would also like to recognize the assistance of Roxanne Denault and her colleagues in the Finance/Treasury Board Library. Their ability to locate and obtain copies of very useful - and occasionally rather obscure - reference materials used in the research for this thesis was greatly appreciated.

I dedicate this thesis to my wife, Deborah, my mother, Margaret, and my late father, Nigel. Deborah, an alumnus of U.B.C. (B.A., English) and Carleton University [B.A. (Honours), Art History], was instrumental in encouraging me throughout my studies and played a significant role in helping to improve the readability of this thesis. Despite never having had the opportunity to attend university, my parents were strong supporters of higher education and believed in the value of hard work and perseverance to do one's best: "If something is worth doing, it's worth doing well." 
CHAPTER 1 - INTRODUCTION.............................................

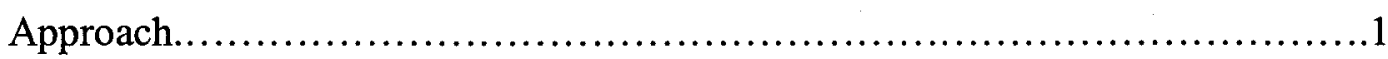

The politics of defining public need..........................................6

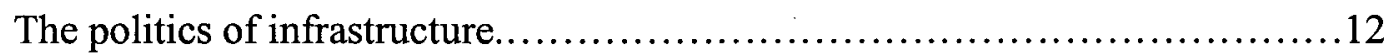

Defining public infrastructure .......................................12

Paying for Public Infrastructure ..........................................15

Defining the Infrastructure problem.................................17

CHAPTER 2 - FEDERAL INVOLVEMENT IN

MUNICIPAL AFFAIRS $(1918-1984) \ldots \ldots \ldots \ldots \ldots \ldots \ldots \ldots . . .21$

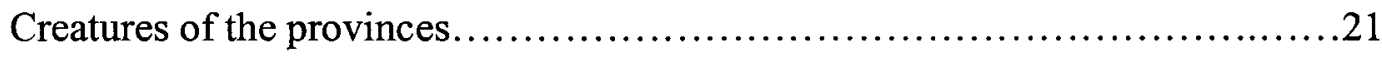

Early Federal Involvement in Municipal Affairs..............................25

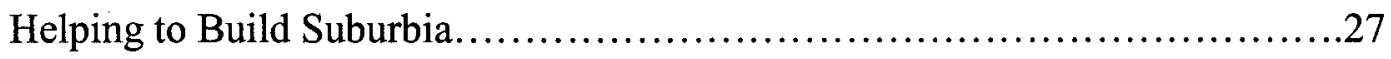

Urban Affairs - a new federal policy.......................................32

Federal Retrenchment from Urban Affairs...................................36

Municipal demands for increased autonomy and revenues..................... 37

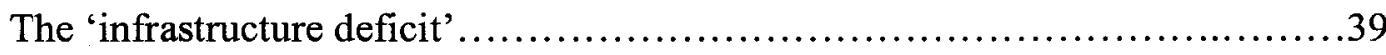

CHAPTER 3 - THE MUNICIPAL INFRASTRUCTURE PROGRAMS

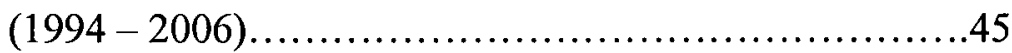

The FCM shapes the discourse...........................................46

The Liberal policy response.................................................49

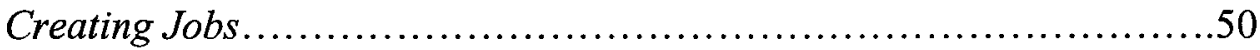

Supporting economic growth .......................................51

Enhancing Community Liveability ......................................52 
Intergovernmental Cooperation...................................54

The Canada Infrastructure Works Program (1994-1999).....................55

Program Design ..............................................56

Auditor General's Observations...................................59

Program Evaluation...........................................63

The Infrastructure Canada Program (2000-2007)...........................74

Program Design..................................................

Program Results..............................................81

The Canada Strategic Infrastructure Fund (2002- )........................87

Program Design..................................................91

Program Results...............................................98

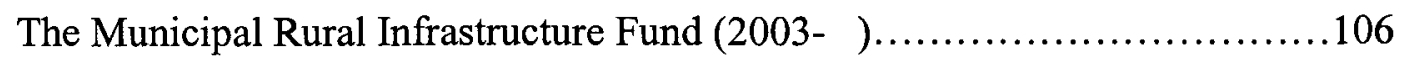

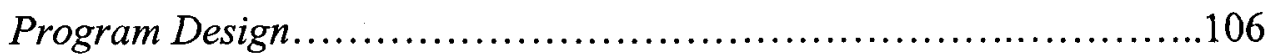

Program Results.............................................107

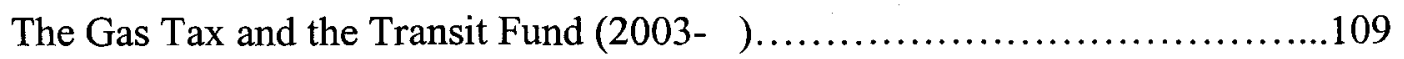

Gas Tax Fund: New Deal or Another Transfer Program?..............111

Public Transit Fund...............................................117

Public Transit Capital Trust..........................................118

After a decade of municipal infrastructure programs......................120

CHAPTER 4 - THE EVOLVING MUNICIPAL 'PROBLEM' $\ldots \ldots \ldots \ldots \ldots \ldots \ldots \ldots . \ldots 127$

Reshaping The Discourse......................................... 128

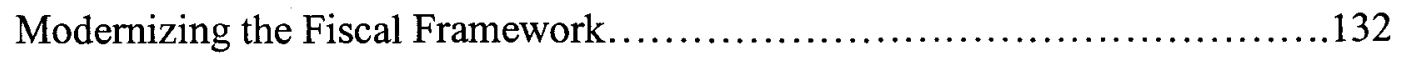

Changing municipal practices...................................... 144

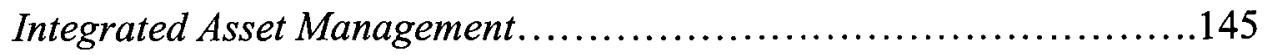

Demand management for municipal services........................147

Alternative Service Delivery.................................150 
CHAPTER 5 - CONCLUSION.................................................... 157

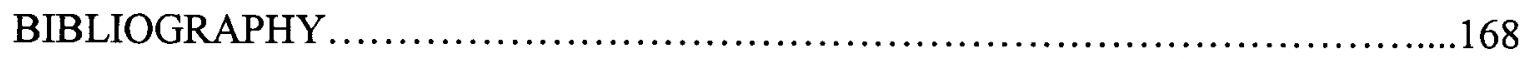




\section{LIST OF TABLES}

Table 1 - Infrastructure Management Terminology ..............................

Table 2 - Perceived Urban Crises and Federal Policy Responses......................24

Table 3 - FCM Survey: Priority vs. Condition.................................41

Table 4 - CSIF Act Definitions............................................... 92

Table 5 - Gas Tax Fund 'Capacity Building' .................................. 113

Table 6 - Objectives of the Municipal Infrastructure Programs..................... 124

viii 


\title{
CHAPTER 1
}

\section{INTRODUCTION}

\begin{abstract}
At the nexus of politics and policy development lies persistent conflict over where problems come from and, based on the answer to this question, what kinds of solutions should be attempted. (Rochefort and Cobb, 1994, 3)
\end{abstract}

\section{Approach}

While the federal government has no responsibility under the Constitution Acts (1867 and 1982) for funding public infrastructure that is owned and operated by municipal $^{1}$ governments, since 1993 successive Liberal and Conservative governments were convinced of the need to transfer billions of dollars of federal revenues in support of municipal capital projects. This thesis examines the public policy framework underpinning the government's decisions in this regard, exploring the evolution of the need for funding municipal infrastructure that was identified, conceptualized and advanced as a 'crisis' requiring ongoing financial assistance from the federal treasury.

In responding to this issue, the federal government implemented a series of programs that transferred revenues to support more than 22,000 municipal infrastructure projects. As a condition of receiving federal funds, these projects were supposed to fulfil a variety of policy objectives, producing tangible economic benefits, improving the quality of life of citizens, and creating positive effects on the environment. ${ }^{2}$ As Rochefort and Cobb observed, "in politics ....the use of rhetoric is key to the process by

\footnotetext{
${ }^{1}$ While recognizing that the term 'local government' is a more inclusive term, the thesis will nevertheless refer to 'municipal governments' throughout as it is employed generically in the media and policy papers to the describe the governance of communities.

${ }^{2}$ The programs and their policy objectives are presented in Table 6 on page 124. The initiative that transfers revenues for municipal transit infrastructure - the Public Transit Capital Trust - is not a program per se, as is explained in Chapter 3.
} 
which ...decisions are justified, promoted, and even placed beyond questioning" (1994, 7). We will argue that the policy objectives used ostensibly by the federal government to justify its revenue transfers to municipal governments were more rhetoric than substance. Through a deconstruction of the policy framework and an examination of the municipal infrastructure programs that were implemented, we conclude that the rationale for sustaining these programs was rooted not in public policy but in distributive politics. ${ }^{3}$ By availing themselves of ongoing opportunities to engage in the retail politics offered by these programs, the Liberal governments of Jean Chrétien and Paul Martin (and later the Harper Conservatives) were able to pursue their political objectives, transferring federal revenues to municipalities as a means of building political capital.

Spending on public infrastructure that is based on distributive politics masks the real costs of capital investments and undermines the application of efficient pricing policies. The political expediency associated with this kind of spending weakens the accountability of decision-making about local public assets. Rather than promoting the principles of sustainable development and integrated asset management, this spending supports short-term political interests.

While some scholarly analysis [Andrew and Morrison (1995 and 2002); Soberman (1996); Kitchen (1995)] was carried out on the Chrétien government's initial municipal infrastructure program, ${ }^{4}$ there has not yet been a comprehensive examination

\footnotetext{
3 'Distributive politics' is defined as "the politics of expenditure programs where the benefits can be targeted to specific localities, paid for via general revenues" (Wiengast, 319). For another view on the subject, see Bickers and Stein, "Response to Barry Weingast's Reflections."

${ }^{4}$ The Canada Infrastructure Works Program (1994-1999) involved transfers of \$2.4 billion from the federal government.
} 
of the federal programs in toto. ${ }^{5}$ Considerable study has been carried out on the need for alternative sources of financing for municipal infrastructure (Silver; Kitchen; Slack; McMillan; Mintz; Roberts; and Vining), although the analysis to date has not been situated within the context of all federal infrastructure programming. While the federal government continues to maintain an active role in financing municipal infrastructure, ${ }^{6}$ the larger public policy debate has yet to address alternatives that would rebalance the revenues provided to government, particularly the federal government, which has been posting billions of dollars in surpluses since the late 1990s. There are alternatives to transfers from senior levels of government to municipal governments that offer better results both in terms of generating adequate sources of revenue for infrastructure and providing clearer accountability for the expenditures of these revenues. The thesis examines these alternatives and argues that new approaches to funding municipal infrastructure are needed.

In order to explore this subject, we first present the approach used in our analysis of public policy. The thesis draws on the works of Fraser, Stone, and Rochefort and Cobb, who have explored how and why issues defined as public problems become worthy of public policy intervention, are transformed within the political arena and then subsumed within broader government agenda. By applying this approach to the analysis of public policy development, it is possible to understand how the municipal

\footnotetext{
${ }^{5}$ The Auditor General of Canada has yet to carry out an audit of the federal government's municipal infrastructure programs launched since 2000. During the Canada Infrastructure Works Program the Auditor General conducted two audits.

${ }^{6}$ During the 2006 federal election campaign, the Conservative government had campaigned on their commitment to maintain the funding for the New Deal for Cities and Communities and to expand it by using gas tax transfers "to build and repair roads and bridges to improve road safety and fight traffic congestion."
} 
infrastructure problem was framed for political discussion and action by the federal government.

Within the context of how public policy is shaped through the definition of a problem or need, we then clarify what is meant by public infrastructure as well as related terminology involving capital investments at the municipal level of government. These clarifications serve as the foundation for our examination of how the need for funding municipal infrastructure was defined and interpreted within the process of developing the federal government's policy response.

In Chapter 2, we examine the origins of the federal government's involvement in providing financial assistance for municipal public infrastructure. During the decades after World War I until the 1980's, the federal government responded to various social and economic problems by creating short-lived municipal programs that provided loans and grants for local public works projects. Many of these problems were triggered by federal policies that had produced unanticipated negative effects on municipal governments. Federal assistance was reactive - countermeasures intended to provide short-term financial relief.

In Chapter 3, we examine the federal government's municipal infrastructure programs implemented since 1993 and explore the origins of the need that drove the public policy response to create them. For each program, the federal government identified a number of policy objectives that were intended to rationalize its financial support for municipal infrastructure. However, these objectives served more as camouflage for the creation of opportunities supporting retail politics and 'pork barrel' spending. Rather than introducing positive measures to strengthen local accountability 
and decision-making for municipal infrastructure, the federal transfer programs have undermined the application of efficient pricing policies and thwarted the implementation of municipal practices that would be supportive of the principles of sustainable development.

In Chapter 4, we examine how the discourse about the municipal infrastructure problem is being reshaped. After more than a decade of federal infrastructure programming that has transferred billions of dollars for municipal capital projects, the problem facing municipal governments is being redefined. While municipal governments are still seeking federal financial assistance for capital projects, they are now also calling for measures to restore the 'municipal fiscal balance.' We will explore the need for these measures as well as alternative approaches to revenue transfers from senior levels of governments and consider whether they would offer better results.

In Chapter 5, we present conclusions and present some suggestions for the federal government with respect to its involvement in supporting municipal infrastructure. Rather than continuing to focus on infrastructure projects, the federal government should resolve the broader structural problems facing municipal governments, including their fiscal capacity to deal with their public assets over the longer term. Greater focus is required to support a transformational change in the way public capital is funded and managed, changing how municipal governments plan for growth, price their services and generate revenues. 


\section{The politics of defining public need}

In his work on public issue management, Pal observed that "Governments may do things for a wide variety of reasons - patronage, political competition, reflex, tradition but when their actions are grounded in policy, they presumably are taking a course of action that has been thought through in terms of the nature of the problem they are addressing and the circumstances they face" $(2006,1)$. Public policy in this context can be viewed as a compass or mental construct within the decision making process. For Pal, it is "a guide to action, a plan, a framework, a course of action or inaction designed to deal with problems" (5). A rational approach to developing public policy follows a logical sequence of events and includes a complete and thorough analysis of a given public issue or problem and its causes before government action begins.

As Rochefort and Cobb note, however, “... empirical evidence repeatedly refutes this portrayal (of public policymaking) ... Not only is there a degree of arbitrariness about what is taken to be a serious problem, but controversy often surrounds how a given issue will be understood" $(1993,56)$. Success in shaping an issue's meaning is essential to the process of public policy development, which Stone describes as a "struggle to control interpretations and images..."(282). For Rochefort and Cobb, it is a complex process during which "a series of conclusions, choices, and rejection of alternatives ... are assembled to compose a constructed reality" $(1994,7)$.

How the nature of a public problem or need is understood influences political discussion, the ensuing decisions related to any action to be taken, the creation of a policy framework, and the design of policy instruments. Fraser describes the "politics of needs" as a series of struggles that begin with validating an issue as a matter of legitimate 
political concern, interpreting the need and gaining the power to define it, determining what would satisfy it and finally controlling the satisfaction of the need (294). In order to successfully politicize an issue, Fraser believes that the most critical phase of the struggle is not around who can influence decisions, but who can influence the definition process and control the "interpretation of needs."

An ability to understand the political culture in which public policy is shaped should therefore begin with "discourses about needs" rather than the needs themselves. Fraser observes that, in late-capitalist, welfare-state societies (i.e., industrialized countries of Western Europe and North America), "needs-talk functions as a medium for the making and contesting of political claims ...(it) is an idiom in which political conflict is played out and through which inequities are symbolically elaborated and challenged" (291). Fraser describes needs-talk as the "major vocabulary" of political discourse - "the discursive coin of the realm" (313).

Fraser believes that it is more important to concentrate on the politics of "needs interpretation" than the distribution of "needs satisfaction" since, by focusing on discourses and interpretation, it is possible "to bring into view the contextual and contested character of needs claims" (292). Needs claims are relational, connected to each other in what she calls "ramified chains." The manner in which they can be discerned or "unravelled depends on what the interlocutors share in the way of background assumptions" (293).

Rochefort and Cobb also emphasize the significance of the defining process during the political discourse of policy making, which they describe as the "mechanics of cognition and argument by which problems are defined" $(1994,4)$. Problem definition 
seeks "to explain, to describe, to recommend, and above all, to persuade. It is a distinctive form of public rhetoric made up of a habitual vocabulary" $(1994,15)$. Edleman (1988) and Ibarra and Kitsuse (1993) observed that the defining process involves "a struggle over alternative realities ... (and) language is the medium that reflects, advances, and interprets these alternatives" (cited in Rochefort and Cobb, 1994, 9).

Like Fraser and Stone, Rochefort and Cobb believe that the way in which political discourse is shaped is key during the struggle to politicize and control a public issue. They argue that "language is essential to understanding, argument, and individual and group expression, which all figure into the definition of social problems for public attention" $(1994,9)$. For Elder and Cobb (1983), "language can be the vehicle for employing symbols that lend legitimacy to one definition and undermine the legitimacy of another - as when professional groups try to gain control over the way a problem is perceived by introducing symbols of their expertise and authority" (cited in Rochefort and Cobb, 1994, 9).

The process of using language and "symbolic representation" to gain control over the way a problem is perceived is at the heart of problem ownership. Rochefort and Cobb cite the work of Stone in this regard, who "points out four prominent forms of language and symbolic representation in political discourse: (1) stories, which provide explanations; (2) synecdoches, in which parts of things are said to depict the whole; (3) metaphors, which claim likenesses between things; and (4) ambiguity, in which multiple meanings are evoked simultaneously" $(1994,9)$.

Stone describes this process as one in which "political actors use narrative story lines and symbolic devices to manipulate so-called issue characteristics, all the while 
making it seem as though they are simply describing facts" (282). Rochefort and Cobb define this process as establishing "political property rights," whereby problem owners dominate the way in which an issue is framed and acted upon in the public arena and "serv(e) as the recognized authority on essential questions of causes, consequences, and solutions" $(1994,14)$. Problem ownership also extends to what Hilgarter and Bosk refer to as the "specialized community of operatives" who advance the theories and data on which policies are based:

When the paradigm of explanation shaping policy development goes without serious challenge, or when challengers are effectively kept on the sidelines in the decisionmaking process - these are signs of ownership in public policymaking (cited in Rochefort and Cobb, 1994, 14).

Since the defining process in public policymaking is crucial to establishing an issue's political standing, the way it is interpreted and the public solutions that will be designed, what factors affect an issue's capacity to be politicized? In what Rochefort and Cobb refer to as the rhetoric of problem definition and its policymaking consequences, they present attributes that contribute to shaping political discourse as well as an issue's "salience" with the public: causality; severity; incidence; novelty; proximity; and crisis.

They note that, "the question of culpability is the most prominent of all aspects of problem definition" $(1994,15)$. Stone describes the process as one that involves "image making where the images have to do fundamentally with attributing cause, blame and responsibility" (282). While attributing blame can provide momentum for an issue or help to dismiss potential alternate interpretations of how a problem is perceived, faultfinding sets up a dynamic that can overshadow the issue itself. Rochefort and Cobb opine wryly that, "(b)laming is one of the great pastimes of politics." Citing Weaver, they caution that generating blame is not without risks; rather, "(it) is a "strategic choice 
that has both potential benefits and costs" $(1994,16)$. The ensuing discourse can remain snarled in contrasting interpretations and assumptions of cause rather than focusing on the need itself: "(a) decision about problem causality can be the linchpin to a whole set of interdependent propositions that construct an edifice of understanding about a particular issue" $(1994,16)$.

Rochefort and Cobb point out that the representation of a problem's severity is particularly significant in needs-talk since it is key to getting the attention of public officials and the media $(1994,17)$. Applying the "severity label" establishes an issue as having crossed a threshold that now qualifies it as worthy of public attention.

Establishing the high degree of seriousness of a problem and a concern for consequences allows an issue to acquire a high priority standing politically. As Rochefort and Cobb note, however, while the extent of an issue's 'reach' is important it is not pivotal: “... it helps if an issue affects large numbers of people. Alternatively, devastating impacts on a few can also make a problem noteworthy" $(1993,64)$.

While describing a problem in terms of its frequency of occurrence and its prevalence, "(o)ften ...the argument is simply over selecting the most accurate, nondistorting statistic to represent a problem" $(1994,20)$. However, as Rochefort and Cobb observe, the intermix of politics and available information in gauging incidence can be dangerous when statistics are employed: "Linear or even exponential projections are the most ominous, and when accepted as valid, tend to create the most pressure for quick intervention" $(1993,64)$.

Presenting a problem as "novel, unprecedented, or trailblazing" allows it to stand out. When such an issue includes a high 'severity' label, it is able to gain traction very 
quickly in the media. However, the novelty feature of a problem can erode quickly: “... a tension arises, as the issue is publicized and onlookers expect resolution, yet no consensus exists within the political system on how to tackle the problem" $(1993,65)$. Describing a problem's proximity relates an issue to the public's own interest. Establishing the personal relevancy of an issue allows it to "hit close to home." It is a particularly powerful element in communicating the legitimacy of the need for government action.

As Rochefort and Cobb observe, "Crisis' is undoubtedly one of the most-used terms in the political lexicon" $(1993,66)$. Describing a problem as a crisis or emergency sets a level of urgency that can no longer be ignored. Dire circumstances exist when an immediate response to correct a situation is needed and where action is long overdue. Given its power to attract media attention, stating that an issue is a crisis therefore gains significant political capital in the short term. However, as in describing a problem as "unprecedented." the allure of the crisis label can wane quickly. As Rochefort and Cobb point out, "( $\mathrm{t}$ )he dividing line between a mere problem and an actual crisis is indeed a hazy one which issue advocates are prone to cross rhetorically when they see momentum for their cause waning" $(1993,66)$.

Fraser's discussion of the politics of needs interpretation together with Rochefort and Cobb's observations on problem definition provide a useful framework for understanding the significance of defining and interpreting public issues in shaping the political discourse involved in policy making. With this understanding of how and why issues or needs defined as problems worthy of public attention are transformed within the political arena, we now outline the complexity of the public infrastructure 'problem.' 


\section{The politics of infrastructure}

Rochefort and Coleman's observation that controversy often surrounds how a given issue will be understood in shaping public policy aptly describes the discourse pertaining to the infrastructure problem. There are differences of opinion about what the problem is and even contrary views that challenge whether it really exists. However, before we explore the 'needs-talk' about public infrastructure, it is first necessary to clarify some of the terminology that relates to the issue.

\section{Defining public infrastructure}

According to Poisson, "there is no consensus among experts as to what constitutes infrastructure" (cited in Vander Ploeg, 4). While a broad definition may be elusive, we can establish some basic parameters as to what is meant by 'public' infrastructure. Broadly speaking, public infrastructure can be defined as "the network of public works which are basic to the economic and social life of any nation state" (Webley, 1). The network involves capital stock or assets ${ }^{7}$ that are owned and operated by government and provide the basic underpinning for the delivery of public services. ${ }^{8}$ The public nature of these assets is found in their purpose to deliver collective benefits to society and in the responsibilities of government to manage and maintain them (TD Economics, 2004, 2).

\footnotetext{
${ }^{7}$ While definitions vary of what is meant by 'capital assets,' it is usually defined within government as physical or fixed assets that are developed or otherwise acquired and are (a) held for use in the delivery of services or government programs (b) have a useful life extending beyond one fiscal year and are intended to be used on a continuing basis (c) are not intended for resale in the ordinary course of operations. Adapted from Treasury Board Accounting Standard 3.1

${ }^{8}$ The concept of 'public infrastructure' pertains to assets that are owned by government, although there are also instances involving privately owned capital assets that provide services on behalf of government. These arrangements will be discussed further in Chapter 4 .
} 
According to data from Statistics Canada, municipal governments constitute the largest asset owners in the country, being responsible for more than half of public infrastructure. Of the remaining public assets, the provinces and the territories hold approximately 40 per cent and the federal government much less: 7 per cent (cited in Vander Ploeg, 3). Regardless of the size of a municipality, those who are elected to govern it are accountable to citizens for managing the capital assets required to deliver public services and for meeting specific service standards. Levels of service incorporate the social and economic goals of the community in both capacity and maintenance or operation and are usually measured according to several variables including safety, customer satisfaction, quality, quantity, capacity, reliability, responsiveness, environmental acceptability, cost, and availability (InfraGuide, 2003). However, as Soberman observes, "Infrastructure and adequate standards of service have long been treated as public goods to be provided by government, usually at no direct charge or charges that are far less than actual cost"

(vol. 1, 2).

While a municipal government is accountable for delivering levels of services according to what the majority of citizens are willing to pay, ${ }^{9}$ mandated service levels and their costs can also be driven by external factors such as regulatory requirements prescribed through provincial or territorial legislation. These normally include mandatory standards relating to the quality of potable water and the treatment of wastewater before it is released into a watershed. In such cases, senior levels of government may provide

\footnotetext{
${ }^{9}$ A broader discussion of the financial aspects of paying for public services will be discussed further in Chapter 4.
} 
grants to municipal governments to offset the increased costs imposed by changes in legislation.

While the types of services provided by municipal governments vary somewhat according to what is set out in provincial legislation, ${ }^{10}$ in general these assets include those involving the provision of transportation services (roads, bridges, and transit), environmental services (water treatment and distribution, waste water - sewers and storm water - collection and treatment, solid waste collection and disposal), protective services (police and fire), social and health services (welfare administration, social housing, day care, homes for the aged, public health programs) and amenities such as parks, recreation, cultural and community services.

Vander Ploeg observes that individual municipalities have varying interpretations of terminology relating to the management of infrastructure, such as 'capital,' 'capital acquisition,' 'minor maintenance,' 'major maintenance,' 'rehabilitation,' 'replacement' and 'capital renewal.' While Vander Ploeg's definitions of these terms are particularly instructive in differentiating and clarifying the needs of infrastructure investment from a technical perspective (see Table 1), these fundamental terms are understood differently across the country. As a consequence, it is difficult to provide a credible assessment of the extent of the infrastructure problem nationally.

Although Rochefort and Cobb point out that language is fundamental in understanding, argument, and individual and group expression, the murkiness in the vocabulary related to the management of infrastructure has led to confusion rather than

\footnotetext{
${ }^{10}$ As Tindal and Tindal observe, the concept of municipal governments as 'creatures' of the provincial governments is very clear under the Constitution: "...municipal governments have operated since Confederation within a constitutional and legal framework, reinforced by ample case law, which limits their scope to matters specifically delegated to them by the provincial governments which have established them" $(2000,9)$.
} 
clarity and shared understanding. The imprecision in language has carried over into political discourses about the need for more funding for municipal governments. There are also different approaches to capturing costs related to capital assets.

\section{Table 1 - Infrastructure Management Terminology}

Capital Acquisition: Constructing new infrastructure or purchasing a new asset that did not previously exist. Costs reflect a number of sub-components such as engineering specifications, design, manufacturing, installation, and commissioning.

Minor Maintenance: A broad range of planned activities intended to preserve the service life of an infrastructure asset and to ensure it remains in a condition to serve the purpose for which it was intended. These include inspections, monitoring, cleaning, flushing, and testing. These activities are preventative in nature.

Major Maintenance: This activity is usually unplanned and occurs as a result of failure. It includes small repairs and actions to restore small components of a system. This expenditure is corrective in nature.

Rehabilitation: This activity is a major scheduled event intended to restore a significant component, system, or entire asset or facility to its former condition. Additional labels for this expenditure include upgrading, adapting, expanding, and converting. Rehabilitation improves a system and can also extend its lifespan.

Replacement or Capital Renewal: This refers to a planned activity that entirely replaces a current system because it has reached the end of its useful (or serviceable) life. Replacements can also occur for reasons of economic efficiency, obsolescence, modernization, or compatibility with other systems. This could also include the costs related to disposal of assets

Source: Vander Ploeg, 2003, 5 - "Clarifying Definitions".

\section{Paying for Public Infrastructure}

Public funds for infrastructure are provided for expenditures related to the creation of new assets and to the care of existing assets. The former could involve acquisitions made as the result of additional services to accommodate population growth, new construction that advances or completes ongoing programs and priorities as well as providing an entirely new service, and infrastructure required to meet changing 
standards. ${ }^{11}$ The latter usually relates to spending in order to maintain, rehabilitate, or replace and renew existing assets that have become obsolete or have outlived their useful lives.

As well as noting variations in how technical terms relating to the management of infrastructure are understood, Vander Ploeg found that there are major differences among municipal governments in how disbursements for infrastructure are treated: "The words infrastructure spending, infrastructure investment, capital spending, and capital investment are often used interchangeably. But, they do not always carry the same meaning" (5). The differences have much to do with varying interpretations of the purpose for these disbursements:

Some prefer the word 'spending' to emphasize that infrastructure consumes revenue, while others prefer the term 'investment' to underscore the point that infrastructure can increase revenues down the road in the form of economic growth, increased productivity, and more tax revenue (5).

The differences in how disbursements for infrastructure are viewed carry over into how the costs of routine maintenance of capital assets are treated. As Vander Ploeg points out, while maintenance costs relate unquestionably to ensuring the long-term preservation of assets, it is common practice in municipal governments to treat these amounts as operating costs that are included on the current account rather than on the capital account as 'capital costs.' While the manner in which these costs are placed on the financial ledgers may appear as an arcane matter of interest only to accountants, this practice has a major impact in defining 'infrastructure needs.' Vander Ploeg observes

\footnotetext{
${ }^{11}$ An example of this is found in changes to provincial legislation for health and safety related issues, such as Bill 175 in Ontario, which established the Sustainable Water and Sewage Systems Act (2002). The legislation introduced new regulatory requirements relating to reporting on the provision of water services and wastewater services, including the infrastructure that was needed to provide these services (specifically, an inventory of and management plan for the infrastructure needed to provide the water services, prepared and certified by a professional engineer). Bill 175 also imposed requirements pertaining to the full cost of providing these services and the revenue obtained to provide them.
} 
that, "...this is highly problematic if only because many estimates of infrastructure 'deficits' are based on a backlog of deferred maintenance - amounts the term 'capital' does not capture" (6). In order to accurately capture infrastructure 'need,' costs pertaining to the preservation of assets should be viewed more as capital investments spread out over time (5).

\section{Defining the Infrastructure problem}

While the value of public infrastructure in municipalities across the country is "a measure of the amount of capital in existence at a particular point in time," this value changes as new assets are added and existing infrastructure is replaced (Marchaoui, Tarkhani and Warren, 5). Determining municipal infrastructure needs or requirements and calculating the financial resources that are necessary for addressing them therefore demands an ongoing assessment of the condition of public assets as well as predictions about their remaining service life and estimates of the associated costs of maintenance and capital renewal for these assets. ${ }^{12}$ As Mintz observes,

...the emplacement of infrastructure is not the passive result of economic determinism; infrastructure investment follows from conscious decisionmaking. The welfare and economic health of a nation's population depends in part on the quality of decisionmaking and that quality depends, in turn, on the information set and the analytical framework within which relevant information is considered (Vining and Richards, 2001, Forward).

A number of estimates have been made on the extent of unfunded public infrastructure needs for selected public service sectors in Canada, including those relating to municipal governments. The unfunded needs have been referred to as the 'infrastructure deficit' although, as Vander Ploeg points out, "its meaning is not altogether clear, and it has also been used in misleading ways" (6). Some estimates of the

\footnotetext{
${ }^{12}$ These goals were presented as the conclusions put forward in a report written by Vanier and Rahman in February 2004.
} 
infrastructure deficit, for example, include the need for new assets required to meet the demands of population growth. Vander Ploeg concludes that, “...there is a strong subjective element to the notion of an infrastructure deficit or debt, particularly as it relates to measuring infrastructure requirements - it is difficult, if not impossible to separate 'wants' and 'desires' from actual 'needs"' (6).

While a deficit is usually defined as an annual shortfall between what is required and what is ultimately available to meet the requirement, the needs-talk about the infrastructure deficit is not based on credible evidence:

In any political and economic debate it is often difficult to separate myths and half-truths from reality. Many of the same difficulties apply in the discussion over infrastructure. Numerous facts and figures are tossed into the public arena where they are often accepted without question ...(Vander Ploeg, 1).

Mintz criticizes the often cited ' $\$ 60$ billion deficit' used in the needs-talk about infrastructure. He argues that " $(\mathrm{t}) \mathrm{he}$ method for estimating the national infrastructure shortfall would embarrass an undergraduate statistics class." Since the calculation involved a projection that was derived from two data points, he concludes that the estimate was "bogus" since it was "based on unacceptable economic evidence" (2005). From his review of several studies and reports on the infrastructure problem, Kitchen also concludes that "there is little that one can conclude about the consistency or uniformity of the methodology employed or the conclusions reached, other then (sic) they all indicate some kind of deficit with the size varying considerably" (2003). ${ }^{13}$

The reason for the wide disparity of estimates is not surprising. Few municipal governments in Canada have accurate and comprehensive information on the condition of their public infrastructure. Even fewer have a consistent approach in managing and

\footnotetext{
${ }^{13}$ Kitchen's report included a review of several Canadian studies that have attempted to measure the infrastructure deficit.
} 
preserving the lifecycle of their assets. A recent survey by Vanier and Rahman that was published by the National Research Council of Canada reveals serious concerns about the state of asset management at the municipal level: $28 \%$ of respondents did not have a system to record asset value; $31 \%$ of respondents were unable to provide their level of deferred maintenance; $30 \%$ saved the historical value of the asset and $58 \%$ saved the current replacement value (v). Vanier and Rahman concluded that:

(t)he various means used to estimate the condition or age of the existing civil infrastructure do not provide a consistent picture of the challenges faced by municipal government in assessing their infrastructure assets. The same is true for extent of deferred maintenance or "maintenance gap." The lack of a consistent approach to determining the actual deficit in the maintenance of infrastructure across the country has resulted in an unclear portrait of the actual costs and impact (vi).

Given the confused language pertaining to the management of public infrastructure and the dearth of accurate and comprehensive information about the condition of municipal assets, it is not surprising that the 'infrastructure problem' is broadly misunderstood. However, the absence of credible and quantifiable data has worked to the advantage of municipal governments and their advocates such as the Federation of Canadian Municipalities (FCM). As owners of the infrastructure 'problem,' they have been successful in the struggle to politicize the public debate about the issue by shaping the political discourse as well as the federal policy responses to it.

This thesis will argue that, in the absence of a clearly defined problem, the federal government created a policy framework founded on rhetoric rather than substance. In rationalizing the decisions to launch a series of ad hoc infrastructure programs that transferred billions of dollars in revenues to municipal governments, the federal government employed ambiguous language to define a vague public policy 'need.' 
While claiming that its investments in "strategic" municipal infrastructure had an impact on the economy, the environment and the 'quality of life' of citizens, the funding was allocated according to 'distributive politics.' In the absence of a clear plan or strategic policy, federal funding was sprinkled across the country for a myriad of infrastructure projects that served not as vehicles for the realization of policy objectives, but as opportunities to engage in retail politics and build political capital.

In order to examine of the evolution of the 'infrastructure problem' - how it was shaped in political discourse as a public policy 'need' and became embedded in federal policymaking and programming - we first examine the origins of the federal government's involvement in providing financial assistance for municipal public infrastructure. This context is critical to understanding the process that drove the public policy related to infrastructure that led to the creation of the infrastructure programs in the 1990s. 


\title{
CHAPTER 2
}

\section{FEDERAL INVOLVEMENT IN MUNICIPAL AFFAIRS}

\author{
(1918 - 1984)
}

\begin{abstract}
... not only were municipal governments facing the pressures of an urbanizing trend largely shaped ... by the policies of the senior levels of government but they were also constrained in responding to these pressures by the extent to which their responsibilities were entangled with those senior governments (Tindal and Tindal, 2000, 77).
\end{abstract}

During the decades after World War I until the 1980's, municipal governments received federal loans and grants for a wide variety of local public works projects as a means of addressing problems such as high unemployment, housing shortages, urban decay and environmental degradation. As Wolfe (2003) observed, many of these public crises were triggered by federal government actions - policies relating to immigration, housing development, and transportation - or inaction, such as the failure to anticipate the effects of demobilization following World War II. Before we consider the federal government's role in this regard, it is important to provide some context to the provision of municipal services and the associated public infrastructure.

\section{Creatures of the provinces}

The development and maintenance of local infrastructure in Canada falls exclusively under the jurisdiction of provinces and their municipal governments. ${ }^{14}$ The role of the federal government is limited to 'local works and undertakings' that are

\footnotetext{
${ }^{14}$ Section 92 of the Constitution Act (1867), sets out the exclusive powers of provincial legislatures in 16 areas, with section $92(8)$ giving the legislature of each province exclusive responsibility for making laws relating to that province's municipal institutions.
} 
excluded from provincial authority. ${ }^{15}$ The federal government has traditionally exercised its responsibilities for infrastructure development by creating national and regional infrastructure systems that were of strategic importance to the nation. Its investments have involved in large measure surface, marine and air transportation systems that have supported domestic and international trade and commerce (marine ports, the transcontinental CPR, CN rail, canals, the St. Lawrence Seaway, the trans-Canada Highway, and airports). Transportation infrastructure was a key instrument in nation building, giving the country shape and transforming it physically, economically and politically. $^{16}$

Canadian municipalities, as Collin and Léveillée observe, “are not the product of the popular will, but rather of the will of the provincial governments that created them" (8). In the absence of being recognized under the Constitution as a separate level of government, municipal governments have remained as 'creatures' of provincial governments, legally subordinate to them and dependent on provincial legislation for defining the parameters of their authority and sources of revenue. As Tolley and Young point out, this subsidiary status has made municipalities particularly.vulnerable:

\footnotetext{
${ }^{15}$ According to Section 92, paragraph 10 of the Constitution Act (1867), the federal government's role in the provision of infrastructure is 'national' although it was not been defined as such. Rather, the few federal powers in this area were limited to 'Local Works and Undertakings' that are excluded from provincial authority. The federal government is responsible for infrastructure that connects provinces to each other as well as that which, "although wholly situate within the Province, are before or after their Execution declared by the Parliament of Canada to be for the general Advantage of Canada or for the Advantage of Two or more of the Provinces." The authority given to the federal government can be interpreted as that which deals with infrastructure spill overs - public works that support national rather than provincial or local interest.

${ }^{16}$ While there is no argument as to the transformative nature of these investments, the federal government's actions were largely reactive. The development of transportation infrastructure was in large part a response to the threat of possible absorption by the U.S. Such a view is consistent with Aitken's argument that Canada's early development was driven by "defensive expansionism." See Hugh G. J. Aitken, "Government and Business in Canada: An Interpretation," Business History Review, Vol. 38, No. 1, International Government-Business Issue (Spring, 1964), pp. 4-21.
} 
The scope of provincial control over municipalities is largely unfettered, and municipal responsibilities can be altered by votes of the provincial legislature. Although some cities have a separate legislative provision establishing their jurisdiction, most municipalities get their powers from a provincial municipal Act that applies to all local entities within a province. The provinces can alter municipalities' boundaries or powers, as well as their financial resources, and can abolish individual municipalities (2).

Their dependence on the provinces and the restrictions placed on their autonomy, decision-making, and sources of revenue have remained major points of contention with municipal governments. The level of dissatisfaction has increased particularly since the country's population has shifted from rural to urban settings, straining the capacity of larger cities and urban regions to meet the demand for increased levels of service and the infrastructure required to support it.

While the constitutional/jurisdictional authority of the provinces with respect to their municipalities is clear, this has not prevented direct federal intrusions in this area of exclusive provincial jurisdiction. As Tolley and Young point out, "Because of the broad range of federal activities that impinge on local areas ...the provinces have not been able to prevent at least ad hoc contact between federal departments and the municipalities. Historically, such linkages have followed informal and functional lines" (4).

The Auditor General of Canada has noted that, "over the years, the federal government has occasionally provided financial aid to provincial and municipal governments to support investment in local infrastructure" (1996, para. 26.11). The use of the expression 'financial aid' in this sense is quite appropriate since the federal government's involvement was very similar to that of a bank. Federal participation was temporary and arms-length, limited to providing either loans, unconditional transfers of funds (grants) or alternatively 'conditional payments' (contributions). As Soberman 
points out, "municipal needs have never been a matter of continuing, direct federal government concern" (vol. 1, 2).

The federal government's rationale for providing financial assistance has varied over time, as has the means of transferring its revenues. As Wolfe observed, federal involvement in municipalities has been more reactive than anticipatory, driven by one crisis after another. She groups the "perceived urban crises" and the federal government's policy responses chronologically into five phases (see Table 2).

\section{Table 2 - Perceived Urban Crises and Federal Policy Responses}

\begin{tabular}{|l|l|}
\hline \multicolumn{1}{|c|}{ Crisis } & \multicolumn{1}{|c|}{ Federal Response } \\
\hline Early 1900s & \\
$\begin{array}{l}\text { Rapid growth/massive immigration; overcrowding; poor housing; } \\
\text { insalubriousness; vice, crime; corrupt municipal governments; } \\
\text { returning veterans; fear of civil unrest }\end{array}$ & Housing Program (1918) \\
\hline Depression & \\
$\begin{array}{l}\text { Unemployment; poverty; overcrowding poor housing; } \\
\text { insalubriousness }\end{array}$ & $\begin{array}{l}\text { Dominion Housing Act (1935); } \\
\text { Curtis Report (1934) }\end{array}$ \\
\hline $\begin{array}{l}\text { Post WW II } \\
\begin{array}{l}\text { Overcrowding; poor housing; returning soldiers; back-log of needs. } \\
\text { Late Sixties }\end{array}\end{array}$ & $\begin{array}{l}\text { National Housing Act (1944); } \\
\text { CMHC (1945)* }\end{array}$ \\
$\begin{array}{l}\text { Rapid growth; housing shortages; cost of urban land (speculation); } \\
\text { spiralling interest rates; escalating prices; dissatisfaction with urban } \\
\text { renewal and public housing; environmental protection movements; } \\
\text { heritage conservation movements. }\end{array}$ & $\begin{array}{l}\text { Hellyer Task Force (1969); } \\
\text { Lithwick Report (1969); } \\
\text { MSUA - Ministry of State for } \\
\text { Urban Affairs (1971-1979)* }\end{array}$ \\
\hline $\begin{array}{l}\text { 21 century } \\
\begin{array}{l}\text { Need for Cities to be globally competitive; people at risk } \\
\text { (homelessness, first nations, etc.); widening polarization of incomes; } \\
\text { shortage of affordable housing; aging infrastructure; environmental } \\
\text { degradation; transportation - inter-city and transit. }\end{array}\end{array}$ & $\begin{array}{l}\text { Issues (2002)* } \\
\text { PMs Task Force on Urban } \\
\text { * Note: Either through design or omission, Wolfe does not include federal programming (loans and } \\
\text { grants) for municipal infrastructure as responses to these crises. }\end{array}$ \\
\hline
\end{tabular}


The government's responses to these 'crises' resembled those of its policies for industrial development, which as Atkinson and Coleman (1989) observed, have been more reactive than anticipatory. Regardless of the broader nature of these public problems, the federal government's solution invariably involved the creation of short-term programs that were designed as national policy responses to address local problems or needs.

\section{Early Federal Involvement in Municipal Affairs}

From Confederation until the end of the First World War, the federal government showed little interest in the affairs of municipal governments. However, Canada's vigorous immigration policy in the early part of the $20^{\text {th }}$ Century began to have serious unintended consequences. As Woodsworth observed in 1910, in cities particularly, "conditions of utter squalor, exacerbated by extraordinary rates of immigration," could no longer be ignored (cited in Wolfe, 2003). Driven largely by fears of civil unrest, the federal government created a small housing program that provided \$25 million in loans to provincial governments "for the purpose of promoting the erection of dwelling houses of a modern character to relieve congestion of population in cities and towns" (Jones, cited in Wolfe, 2003). The program continued only for a short time, ending in 1923.

During the 1930's, the federal government responded to the dangers of severe unemployment created by the Depression. The threat of social unrest - particularly in cities - again warranted its involvement in providing financial support to local governments. Some municipalities had defaulted on their outstanding debt and were having difficulties in collecting taxes as a result of increased personal and business bankruptcies. Parliament passed the Municipal Improvements Assistance Act in 1938, 
using a provision of the Bank Act to authorize the federal government to provide municipalities with loans for construction projects such as water and sewage improvements that would create employment. In order to be eligible, projects were required to be "self-sustaining": municipalities were required to ensure that the interest and principal payments would not form part of the general tax levy. Under the Municipal Improvements Assistance Act, a maximum $\$ 30$ million in loans was made available, of which approximately $\$ 7$ million was actually paid out (Auditor General of Canada, 1996, Exhibit 26.1). The Act was subsequently repealed by Parliament in 1948.

In 1935, the federal government entered into housing policy and provided subsidies, beginning with the Dominion Housing $A c t .{ }^{17}$ The Act had two purposes: to assist in the improvement of housing conditions, and to assist in creating employment in the construction and building material industries. The Home Improvement Loans Guarantee Act (1937) assisted property owners wishing to modernize or improve their existing homes.

During World War II, the lack of housing became acute. Driven by the need to provide housing for workers in the burgeoning war-industry, the federal government established Wartime Housing Ltd., a Crown corporation that built partially prefabricated rental houses - 'Victory Homes' - intended to temporarily fill the gap. Wartime Housing bought materials and land, and between 1941 and 1945, constructed nineteen thousand rental houses followed by another thirteen thousand in the two immediate postwar years (Wolfe, 2006). With the end of the program, the houses were sold to their occupants. ${ }^{18}$

\footnotetext{
${ }^{17}$ For details of this Act as well as other Housing Acts, see "Housing in Canada," by F.W. Nicholls, http://www.urbancentre.utoronto.ca/pdfs/policyarchives/1938FWNicolls.pdf

${ }^{18}$ The assets of Wartime Housing Ltd. were transferred to CMHC in 1947 (including the responsibility of housing veterans) through the Veteran's Rental Housing program.
} 
After the war, many veterans moved into Victory Homes and renovated them. ${ }^{19}$

At the close of World War II, the housing crisis worsened as a result of a continued scarcity of building materials and money for home purchases. The federal government provided loans to provincial governments for the purpose of assisting in the construction of houses, chiefly for returning soldiers. Under the Veterans Land Act, the federal government provided direct assistance to ex-service personnel, providing "generous assistance in financing homes for city and other workers on small acreages, outside the high taxation area" (Globe and Mail, 1944).

\section{Helping to Build Suburbia}

As Humphrey Carver ${ }^{20}$ observed in 1948 , with the return of soldiers after the War, "the pinch of Canada's housing shortage was felt keenly by people in all kinds of economic circumstances. This experience was not confined to households at any one economic level" (1). However, the shortage of housing was not sudden; it had been chronic for some time, particularly since 1930 when the in-coming supply of new housing began to lag seriously behind demand. The growth of the urban wage-earner population during the War had finally brought matters to a head. The great mass of this population could not afford to buy the new housing that was needed (Carver, 2).

Carver and the town planners of his generation believed that "well-planned estates containing small, efficient houses of sophisticated design" would strengthen the housing market, creating opportunities "to plan whole neighbourhood units, control their

\footnotetext{
${ }^{19}$ Victory Homes came in two models: a two-bedroom bungalow or a four-bedroom, one-and-a-half storey house. Although very small by today's standards and without basements and furnaces they met the need.

${ }^{20}$ Carver was a founding member of the Canadian Society of Landscape Architects \& Town Planners.
} 
architecture and landscape design, and bring them to completion in an orderly and logical fashion" (5). In his address in 1950 to National Conference Community Planning Association of Canada, Harold Clark cautioned against the form of land development that was already taking place. His description of the approach to land use and residential development at the time eerily foretells the current suburban settings in many of Canada's largest municipalities:

Acre by acre we are transforming beautiful ravines, fields, parklands and wooded sites into dismal rows of unsightly, identical strawberry boxes that will be with us for a generation at least. These will be future slums growing more and more forlorn as dust from the treeless streets settles on them and the occupants abandon all hope of making attractive anything so basically drab. The approaches to our larger cities with rectangular block after rectangular block containing bungalow or semi-bungalow houses varying only in the color of the roofs and minor exterior treatment are a familiar sight to us all (3).

By the 1950 's, the federal government's strategy to encourage the housing market - building suburbia - was well underway. As Goldrick points out, "urban growth became a prime instrument of public policy to stimulate and maintain high levels of economic activity”(cited in Tindal and Tindal, 2004, 75). The Central (now 'Canada') Mortgage and Housing Corporation (CMHC) was established in 1946 by the federal government as the national housing agency responsible for administering the National Housing Act (NHA) and the Home Improvement Loans Guarantee Act, and for providing discounting facilities for loan and mortgage companies. Eight years later, the federal government broadened the National Housing Act to allow chartered banks to enter the NHA lending field. CMHC introduced Mortgage Loan Insurance, taking on mortgage risks with a $25 \%$ down payment, making home ownership more accessible to Canadians. CHMC became the federal government's key instrument in helping to expand the economy after the war. As Lorimer has pointed out, ““...most of the development of 
Canadian cities in the three boom decades from the Forties to the Seventies was a direct consequence of the economic development strategy chosen by Ottawa for Canada"” (cited in Tindal and Tindal, 2004, 77). The regular tally of new housing starts became a primary indicator for measuring Canada's economic performance. Together with the increasing role of automobile manufacturing as a major contributor to the national economy, the plan to 'suburbanize' the country was set into motion. As Chris Leo observed, "all three levels of government became involved in a massive program of government support for suburban development, pursuing policies that not only reinforced the rapidly growing popular preference for the private automobile over public transportation, but also gave it free reign and entrenched it"(cited in Tindal and Tindal, 2004, 75).

With the rapid growth of suburbia, there was an immediate need to build the infrastructure to support it. As Tindal and Tindal observed, "local government's primary role was to provide the physical services needed to support growth and development. The result, according to Lorimer, is that local government became "servants of the development industry that they were supposed to regulate" $(2004,77)$. While the lack of serviced land in and around the larger cities after World War II was a major impediment for homebuilders, by early 1950 this began to change as a result of "a federal-provincial attack upon this problem...(which involved) the joint assembly of land and the provision of services" (Clark, 3). The National Housing Act was amended to authorize cost sharing by the federal and provincial governments for land assembly and servicing ( 75 percent of the cost was paid by the federal government). Municipalities were allowed to participate in the program only if their province passed legislation authorizing the local 
administration of the provincial aspects of these housing activities (Tolley and Young, 6). While the municipalities eagerly accepted federal funding for the development of serviced land, the costs to develop suburbia's thirst for expanded infrastructure started to escalate sharply.

By 1960 , the expansion of new housing was putting significant pressures on the watersheds through the release of untreated municipal wastewater. In 1961, the federal government amended the National Housing Act to require the Central Mortgage and Housing Corporation to assist in the elimination or prevention of water and soil pollution "through making a loan to any province, municipality or municipal sewerage corporation, for the purpose of assisting in the construction or expansion of any sewage treatment project." This was later expanded to include waterworks projects. To accommodate this change to the $A c t$, from 1961 to 1974 the federal government created the Sewer Treatment Program, which provided $\$ 979$ million in loans and $\$ 131$ million in grants to local governments (Auditor General of Canada, 1996, Exhibit 26.1). As Andrew and Morrison observed, the federal government had put the program in place to "counter criticism by municipalities and the construction industry that lack of serviced land was the major impediment to renewed activity in residential construction" $(1995,109)$.

In addition to helping municipalities address the environmental problems resulting from growth, as it had done during the Depression, the federal government again turned to funding municipal infrastructure to create jobs. From 1958-1968, the federal government operated the Municipal Winter Works Incentive to boost employment, providing $\$ 267$ million to municipalities to support 50 percent of direct payroll costs. In his address to members of the Empire Club on December 1, 1960, the 
Minister of Public Works observed that, "in recent months no subject has been discussed so widely in Canada as the question of employment and how to increase it ... the Canadian labour force has grown more rapidly than the increase in the number of jobs" (Walker). The Winter Works program was designed to address severe unemployment occurring especially during the winter season. Estimates at the time put the number of those directly affected by seasonal unemployment - coined at the time as the "annual depression" - at approximately 250,000 (Royal Bank of Canada).

In addition to providing grants to municipalities, the federal government also launched a program to provide loans to stimulate employment. From 1963 to 1966, the Municipal Development and Loan Act established a $\$ 400$ million fund to provide loans to local governments to encourage them to accelerate and expand their capital works programs. To be eligible for a loan, municipal projects had to constitute an addition to, or an acceleration of, an intended program of municipal capital works. ${ }^{21}$. While the effect of the investment was intended to be incremental - increasing employment in the construction industry - the funds were allocated to provinces on the basis of population only. No consideration was given at the time to targeting federal funds to address the specific areas of the country where the need was greatest.

By 1969 , the federal government had committed nearly $\$ 397$ million in 2,429 loans to 1,262 municipalities, although not all of the loans were repaid. The Act authorized partial cancellation ('forgiveness') of the loan amount, with the degree of forgiveness related to the amount of construction work completed by a specified date (the repayment of up to 25 percent of each loan could be forgiven based on the costs incurred

\footnotetext{
${ }^{21}$ For details on the history of the Act see the Research Note "Canada's Municipal Development And Loan Fund (1963-1966)," prepared by Infrastructure Canada in November 2003. Available at http://www.infrastructure.gc.ca/research-recherche/result/alt_formats/pdf/rn03_e.pdf
} 
by the municipalities). More than one-third of federal funding was directed to water and sewer infrastructure with an equal amount applied to the construction of schools, roads and bridges, rapid transit systems and civic administration buildings. A smaller portion of the loans was used for park developments, recreation facilities, hospitals, and power distribution projects. The federal government's loans to municipalities had effectively leveraged nearly twice their value - the provinces estimated that the total cost of the projects receiving funding surpassed $\$ 750$ million (Infrastructure Canada, 2003b).

\section{Urban Affairs - a new federal policy}

By the 1970 's, the federal government started to recognize the impact of the shift in demographics from rural to urban as well as the explosive growth in suburbia. Since Confederation, there had been an eighteen-fold expansion in the number of urban centres with populations over 100,000 and a twelve-fold expansion in the number of cities with populations between $30,000-100,000$ (Lithwick, 80 ). The rate of growth of the largest metropolitan areas was faster than that of all other urban centres. As Lithwick observed, "urban growth ... ha(d) become increasingly polarized in the largest urban centres" (81). Unable to cope with this explosive growth, urban centres were undergoing physical decline. In his report prepared for the federal Minister Responsible for Housing, Lithwick cautioned:

There can be little doubt that the locus of most of our social problems in the future will be the city. Already there is widespread concern over the forgotten urban poor, the alienated young urbanites, the frustrated middle class seeking shelter, the accelerating pollution of the air and water in and around urban communities, the pointless transformation of most of most of our central cities into mammoth parking lots, and the general unsightliness of the urban landscape (13). 
The federal government shifted its attention from suburbia to address the issue of urban renewal and redevelopment. In the 1970 Speech from the Throne, the government acknowledged the "new accumulation of problems" caused by rapid urbanization and committed to "foster(ing) coordination of the activities of all levels of government and contribut(ing) to sound urban growth and development" (Canada, 1970). It was at this time that the federal government formally entered into the realm of urban policy, in a direction that involved more than providing funding for municipal infrastructure.

The Ministry of State for Urban Affairs (MSUA) was established in 1970 with a mandate "to co-ordinate the activities of the government of Canada in establishing cooperative relationships with the provinces and their municipalities for the enhancement of the human environment" (Basford, 766). The policy rationale for altering the machinery of the federal government to include this new mandate was outlined by its second Minister, Ron Basford:

... urban problems and urban opportunities, so pressing, so accelerating and so far-reaching in their effect on Canada, require co-operative mechanisms and approaches from the government. It was this government that sought to persuade others to develop new mechanisms and approaches so that governments at all levels could impose shape and direction on the growth of urban Canada. ...no one level of government could possibly begin to tackle urban problems in the comprehensive way that is required (766).

As Feldman and Milch observed, one study found that by the late 1960s, "'more than 117 distinct programs administered by twenty-seven departments in Ottawa influenced metropolitan development plans"' (cited in Tindal and Tindal, 2004, 207). MSUA was an attempt by the federal government to 'put the federal house in order' with respect to its involvement in urban affairs. 
Municipalities across the country hailed the new federal initiative for its potential to give them access to greater financial resources and to help liberate them from some of the constraints imposed by the provinces. The provinces - particularly Quebec remained sceptical of the new agency and wary even of practical adjustments that might lead to intrusions into their jurisdiction (Tolley and Young, 6). MSUA had a short lifea single decade, from 1970 to 1979 . Its demise can be attributed in part to the effects of a declining economy, the refocusing of the federal government on other matters and to the changing dynamics that characterized federal-provincial relations at the end of the decade. As Tolley and Young point out, the close relationship between MSUA and municipalities threatened the provinces: "the municipalities' involvement in the constitutional debate ultimately challenged provincial pocketbooks and eventually led to the downfall of Trudeau's intervention in federal-municipal relations" (7). While a detailed analysis of the reasons for its failure are beyond the scope of this thesis, it is important to point out that MSUA's influence was not insignificant. Its research and policy studies related to urbanization were widely disseminated (Tindal and Tindal, 2004, 208).

During the 1970's, the federal government launched one of Canada's more comprehensive tri-government neighbourhood revitalization initiatives. From 1973 to 1979, the Neighbourhood Improvement Program (NIP) provided $\$ 100$ million in loans and $\$ 200$ million in grants to help municipalities to arrest decline and revitalize older neighbourhoods. Funding was targeted to improve community facilities (such as parks and street lighting) and required the approval of the local community. The active involvement of area residents in setting planning priorities for the use of NIP funds was 
an innovative development in community consultation and decision-making. When NIP ended, one hundred and twenty-five towns and cities across Canada had participated, two hundred and seventy neighbourhoods had been improved, and over three hundred and ten thousand houses were rehabilitated. ${ }^{22}$

From 1975 to 1978, the federal government also introduced the Municipal Infrastructure Program, contributing over $\$ 1$ billion in loans and $\$ 395$ million in grants (Auditor General of Canada, 1996, Exhibit 26.1). The rationale for federal funding for municipal infrastructure was linked principally to the increasing financial woes of local governments. As the Federation of Canadian Municipalities (FCM) pointed out, infrastructure that had been built immediately after World War II during rapid urbanization "seems to have been maintained at acceptable levels, partly because economic conditions were favourable, partly because so many facilities were new" (1985, 7). By the 1970's, however, the backlog of maintenance and replacement work had begun to mount due to the 'bubble effect' of aging infrastructure: many of the post-war facilities were reaching the end of their lifespan. In addition, the economic morass that was ravaging the country during the decade was taking its toll on municipal budgets: ... the rapid inflation of the 70 s was not matched by a concomitant rise in the rate of taxation. Municipalities were beginning to fund themselves with less money at precisely the same time that more facilities required repair or replacement. Meanwhile, allocations for capital works increasingly had to compete with demands to fund services designed to improve the quality of life. (FCM, 1985, 7).

The fiscal pressures mounted as rates of inflation soared to double digits in the early 1980s. Municipal governments were reluctant to borrow at the high interests rates for fear of placing an even greater strain on municipal finances. As well, new pressures

\footnotetext{
${ }^{22}$ See Canadian Institute of Planners, http://www.cip-icu.ca/English/plancanada/wolfe2.htm
} 
were being placed on municipal business practices. The FCM reported at the time that the "growing concerns for the environment and increased public involvement in decisionmaking ... made reconstruction more difficult, time-consuming and expensive" $(1985,7)$.

\section{Federal Retrenchment from Urban Affairs}

Following the abolition of MSUA in 1979, the federal government curtailed its efforts in dealing directly with local governments, consolidating provincial control over federal funds for urban redevelopment. CMHC funding for the Neighbourhood Improvement Program, for land assembly (the Municipal Incentives Program) and services (the Municipal Infrastructure Program) was put into a single block-funding program (Community Services Contribution Program). From 1979 to 1984, the Community Services Contributions Program provided $\$ 400$ million in grants. However, the provinces allocated funds from the three program areas according to provincial rather than municipal - priorities (Tolley and Young, 7). The federal government launched the Employment Creation Grants and Contributions Program (1982 - 1986), which provided \$205 million in grants and contributions as a means of kick-starting the economy (Auditor General of Canada, 1996, Exhibit 26.1).

Given the weakened fiscal capacity of local governments at the time, grants had now replaced loans as the preferred means of transferring federal funds. The meagre amount that the federal government was willing to part with was reflective of the dire straits of the national economy at the time. As the Minister of Finance observed when he tabled the 1982 Budget:

The recession has been abrupt and severe. Unemployment has reached record 
levels. Business profits have fallen dramatically. Bankruptcies have increased. Demand for goods has shrunk, both at home and in our markets abroad (Canada, 1982).

Municipalities were on the front line of the recession, and through their national representatives lobbied hard for more financial assistance from the federal government.

\section{Municipal demands for increased autonomy and revenues}

During the 1980s, the FCM faced increasing pressure from its members to convince the federal government to renew funding for local infrastructure. The strain on the organization came at a critical juncture, as Stevenson and Gilbert point out. The CFMM-FCM ${ }^{23}$ had undergone two decades of decline in membership following the City of Montreal's decision to withdraw from the organization in 1961:

Membership loss became particularly pronounced during the 1970s. At the lowest point, in 1981, only 176 municipalities belonged, compared with over 300 in the 1960s and more than 1000 today. CFMM's rapid loss of membership during the 1970s - of municipalities of all sizes - was in part due to its perceived closeness to the Ministry of State for Urban Affairs ... MSUA upset just about everyone except interested academics and CFMM (Stevenson and Gilbert, 532).

During the 1970s, the CFMM-FCM had worked closely with and received funding from MSUA, helping to organize tri-partite conferences ${ }^{24}$ that "fuelled municipal aspirations for increased autonomy and for larger shares of public funds..." (Stevenson and Gilbert, 532). However, the participation of the CFMM-FCM in these events heightened concerns for its own effectiveness, as it was increasingly seen as promoting the agenda of the minister of MSUA rather than its own and - more importantly - its members. As

\footnotetext{
${ }^{23}$ The Canadian Federation of Mayors and Municipalities (CFMM) was renamed the Federation of Canadian Municipalities (FCM) in 1976.

${ }^{24}$ The conferences were held in Toronto in 1972, Edmonton in 1973, and Montebello in 1976.
} 
Stevenson and Gilbert observe, a report that was issued in October 1976 for the Bureau of Municipal Research bluntly characterized the pervading view of the FCM as "feeble and ineffective" (4).

In 1976, the CFMM-FCM published Puppets on a Shoe String, a polemic that predicted "the decline and fall of municipal government" and blamed the provinces for their financial problems $(1976,1)$. However, as Rochefort and Cobb (1994) observed, a strategy that assigns blame in problem definition is not without risk. The CFMM-FCM's approach can therefore be seen as somewhat incongruous. Not only was the organization seeking more money for municipal infrastructure from senior levels of government; it was at the same time seeking their support for a solution that would change the Constitution and the system of allocating revenues to all levels of government.

Drawing on a comprehensive set of intergovernmental financial data, ${ }^{25}$ the CFMM cited a growing gap between local revenues and expenditures and concluded that the fiscal imbalance and deficits of local governments resulted from the improper distribution of revenues in the Canadian finance system. The CFMM pointed out that, while the federal and provincial governments had access to a variety of revenue sources, local governments were limited to the non-growth property tax. Puppets on a Shoe String argued in favour of stronger, more autonomous municipal government in Canada that was less reliant on conditional provincial grants and had greater access to a wide range of tax revenues.

In the late 1970s, the FCM again 'tweaked the noses' of the provinces when it lobbied for constitutional changes that would assign powers directly to the municipal

\footnotetext{
${ }^{25}$ The "Report of the Tri-Level Task Force on Public Finance in Canada" was published in April 1976 by the National Task Force on Public Finance, established by the Second National Tri-Level conference held in 1973 .
} 
level of government. It is not surprising that the provincial governments were hostile:

The provinces will jealously guard the constitutional arrangements that give them exclusive control over their municipalities. Any injection of the municipal question into national constitutional discussions has, in the past, provoked a reaction that has jeopardized even the ad hoc relationship between the federal and municipal governments (Tolley and Young, 1).

During the constitutional negotiations that started in the late $1970 \mathrm{~s}$, the provinces collectively dismissed arguments calling for more fiscal powers for municipal governments and opposed changes to the Constitution that would recognize municipalities as a distinct order of government. However, as Tolley and Young point out, the FCM was unclear about what municipalities really wanted:

The municipalities' participation in the round of constitutional talks which began in the late 1970s demonstrated that they again had no clear suggestions. Their position appeared, as before, to be founded on the belief that mentioning municipalities in the Constitution would help them to solve the problem of how to finance the services imposed upon them by more senior levels of government ... the statements of the FCM suggest that municipalities had a greater concern with entrenched financial resources than with entrenched legislative powers (7).

\section{The 'infrastructure deficit'}

Following the proclamation of the Constitution Act in 1982, the FCM changed its strategy, focusing instead "on delivering values to members rather than on fruitless and divisive quests for constitutional recognition" (Stevenson and Gilbert, 535). While it had failed during the constitutional negotiations to secure new and permanent financial resources for municipalities that were entrenched in the Constitution, the organization now proposed a different - although impermanent - solution. The FCM armed itself with the concept of the 'infrastructure deficit' in its struggle to politicize and shape the discourse about the need for more federal spending in municipalities. 
The FCM estimated that the municipal infrastructure deficit was $\$ 12$ billion, describing it as a public policy 'crisis' requiring the combined financial resources of the federal government, the provinces and the municipalities to resolve it. The FCM argued that massive investments were needed in municipalities across the country, and claimed that the required general repair and rehabilitation of infrastructure could be undertaken only through the infusion of public funds from the three levels of government.

The FCM had canvassed its members and asked them to determine the extent to which they felt that public facilities either needed repair or were not acceptable in their present form. From the responses to a subjective and rather self-serving survey, the FCM tabulated a list of the kinds of municipal assets needing repair or replacement and established a ranking of their budget priority (see Table 3). Asset types and their ranking in order of priority were determined according to the percentage of respondents who identified them. In presenting the results of the survey, however, the report also acknowledged that there were significant weaknesses in the methodology that was used, notably the means of assessing the condition of municipal assets:

... because the definition of an acceptable standard of service was left to each respondent's judgment, what is deemed an acceptable condition in one municipality may be considered unacceptable in another. Consequently, the results might be thought of as representing the sum of the perceptions of a variety of communities, rather than as hard data ..." (FCM, 1985, 18-19).

McCracken and Sonnen criticized the FCM's methodology and survey results, which they characterized as "highly suspicious" (147-148). It is widely acknowledged that surveys of this nature tend to produce qualitative rather than quantitative data. As Mirza observed, “... the biggest problem revolves around the fact that the surveys are likely measuring perceived needs as opposed to objective data ... Measuring needs in this 
fashion may produce results, but may not constructively inform public policy" (cited in Vander Ploeg, 9).

Table 3 - FCM Survey: Priority vs. Condition

\begin{tabular}{|l|c|c|}
\hline Service & $\begin{array}{l}\text { Rank/ Budget Priority for capital } \\
\text { expenditures* }\end{array}$ & $\begin{array}{l}\text { Requires some or much repair } \\
\text { Or is not acceptable** }\end{array}$ \\
\hline Roads & 2 & 70 \\
\hline Sidewalks & 10 & 57 \\
\hline Sewage Collection & 5 & 55 \\
\hline Bridges & 7 & 49 \\
\hline Sewage Treatment & 1 & 40 \\
\hline Stormwater Sewers & 6 & 35 \\
\hline Water Distribution & 4 & 32 \\
\hline Solid Waste & 8 & 30 \\
\hline Parks & 11 & 23 \\
\hline Traffic Control Devices & 9 & 21 \\
\hline Buildings & 12 & 20 \\
\hline Museums & 13 & 15 \\
\hline Water treatment & 3 & 12 \\
\hline Transit & 15 & 6 \\
\hline Social Services & 16 & 4 \\
\hline Other & 14 & (Negligible) \\
\hline $\begin{array}{l}\text { Source: Federation of Canadian Municipalities (1985), Figure 3.5 } \\
\text { * Composite ranking of survey participant's priorities (1,2 and 3) for capital expenditures. } \\
\text { ** Percentage of respondents surveyed who identified the need for repairs to the municipal asset. }\end{array}$ \\
\hline
\end{tabular}

The FCM's report conceded that, while the study was useful in providing "an overview of the condition and funding adequacy of Canada's municipal infrastructure, considerably more information is required if the problems it describes are to be solved" (10). The underlying problem of insufficient data was attributed to the fact that there were "no national standards for assessing condition, or for scheduling maintenance or replacement programs" (10). The report concluded that:

...many municipalities were unable to provide data on present needs or on past expenditures or activities of their public works departments.... this lack of information reflects the absence of adequate technical strategies for renewing and maintaining municipal infrastructure. The main elements of such strategies include continuous inventory and condition assessment, means for setting the best time to repair or replace, and efficient technology to get the greatest amount of 
rehabilitation for a given cost unit. These are matters about which much can be done by municipalities and by the professionals they employ to manage their infrastructure (24).

Regardless of the flaws in the methodology used in the survey of infrastructure needs, the results became the primary source underscoring the FCM's claim that the infrastructure deficit was extensive. Having concluded that there was a serious backlog of repair and maintenance needs for roads, sewers, and other types of municipal infrastructure, the FCM argued that a significant infusion of capital from the federal government was required to support the rehabilitation of these deteriorating critical assets.

Despite the FCM's new and more focused mission to secure funding for its member municipalities, the federal election in 1984 changed everything. The FCM had to deal not only with a change in government but also a change in political parties: the Conservatives had replaced the Liberals. Unlike the Liberals, the Tories did not want to intervene in the fractious state of affairs between the provinces and the 'creatures' of the provinces - municipal governments. As Andrew and Morrison observed, with the arrival of the Conservatives the willingness of the federal government to provide funding for municipalities had cooled significantly:

...after phasing out (its municipal infrastructure) programs, the federal government became increasingly insistent that this was an area of provincial jurisdiction. The FCM faced an increasingly difficult environment for promoting a federal spending program in the area of municipal infrastructure $(1995,109)$.

While the Liberal government had been amenable to being an active player in municipal/urban affairs and had even experimented in creating a federal department (MSUA) as its 'single window' to "impose shape and direction on the growth of urban Canada," the Conservative government was not eager to embrace the same concept. The Tories were well aware of the conflicts with provincial governments that eventually led 
to MSUA's demise. ${ }^{26}$ The Conservative government was equally aware of and sensitive to the contentious relationship between the provinces and the CFMM-FCM.

The Conservatives rejected the demand from the FCM for an immediate injection of federal funds for municipal infrastructure, arguing that there were financial, constitutional and policy reasons that precluded them from transferring revenues for this purpose. The views expressed by Tom McMillan - then Minister of Environment clearly defined the reasons for the Conservative government's categorical rejection of the FCM's proposal. In an FCM Backgounder, he was quoted as saying that, "'the Government of Canada cannot at this time re-launch multi-billion dollar national programs to support municipal waterworks projects that according to the Constitution and the provinces themselves, are not in the federal jurisdiction" (cited in Andrew and Morrison, 1995, 109). The Conservative government's position became even more entrenched in the wake of the turbulence created by the failed Meech and Charolottetown Accords.

It is important to note, however, that the Conservative government's rejection of the FCM's proposal was not based exclusively on political concerns. The federal bureaucracy at the time stated its opposition to transferring more federal funds to help out local governments. As Andrew and Morrison observe, there was a solid public policy rationale that underscored their argument against the proposal:

Officials within the Department of the Environment were not at all sympathetic to the FCM proposal because they saw it as acting as a disincentive for municipalities to adopt more rational policies of water management. Federal

\footnotetext{
${ }^{26}$ Tolley and Young point out that MSUA had significantly soured federal-provincial relations. Some provinces had threatened not to cooperate with the federal government in programs of interest to the municipalities. Ontario, for example, had refused to accept CMHC money for a new town in Pickering rather than share planning authority with the MSUA. As a result, the provinces gained even greater power at the expense of the other two levels of government.
} 
officials argued that if municipalities were faced with the real costs of infrastructure renewal, they would be more likely to look at systems of pricing water use, such as metering systems $(1995,110)$.

Despite the opposition to their proposal from the federal Tory government, the FCM continued to press for federal funds and began a well-crafted process to define both a public policy 'need' and policy instruments that were required to address it. The efforts of the FCM were a testament to Foucault's observation that "need is ... a political instrument ..." (cited in Fraser, 291). Despite a vague understanding of what was meant by the municipal 'infrastructure deficit' - what it involved and what it would cost to address it - the FCM was able exercise political property rights for the issue, serving as the recognized authority and dominating the way in which the political discourse was framed and eventually acted upon by the federal government.

The FCM's strategy demonstrated many of the attributes identified by Rochefort and Cobb as crucial to influencing the political discourse about public policy, shaping the municipal infrastructure problem in terms of causality, severity, incidence, proximity, and crisis. Consequently, the FCM was able to control the rhetoric of problem definition and the essential questions of causes, consequences, and solutions. For the FCM, there was only one solution: the federal government had to create multi-billion dollar programs transferred more and more cash. 


\title{
CHAPTER 3
}

THE MUNICIPAL INFRASTRUCTURE PROGRAMS (1994 - 2006)

\author{
Need is ... a political instrument, meticulously prepared, \\ calculated and used. (Foucault, cited in Fraser, 291).
}

We now probe the public policy response that since the 1990 s has provided the underpinning for programs that transferred federal revenues supporting capital projects in municipalities. While the 'needs discourse' permeating the lobby for federal funding for municipal infrastructure has evolved considerably over the last two decades, the policy solution to the infrastructure 'problem' has remained unchanged: the FCM and its members continue to demand more federal spending.

Following the election of the Liberals in 1993, the federal government responded to the FCM's lobby for more funding for municipal infrastructure by developing a series of programs whose rationale was rooted in creating opportunities for retail politics. Rather than focusing on capital investment and renewal, federal spending became swathed in discourse about social investment and improving the quality of life in all communities across the country. Rather than targeting funding for national and regional infrastructure priorities that were of strategic importance to the nation, the programs became more about federal munificence and its doppelganger, distributive politics. The federal government continues to transfer billions of dollars for all types of municipal infrastructure and rationalizes this spending on the basis of vaguely worded policy objectives that rely on ambiguous criteria. 
Following a brief examination of the FCM strategy to control the discourse around the 'infrastructure deficit,' we will explore the evolution of the federal government's public policy framework and the development of infrastructure programs that purportedly addressed the infrastructure 'problem.' The first of these programs - the Canada Infrastructure Works Program - will be subjected to a more in-depth analysis since it established the template for spending federal resources on municipal infrastructure. It established both the approach to policy development and the governance model of the infrastructure programs that followed. As Andrew and Morrison observe, the CIWP illustrates eloquently Fraser's analysis of the 'politics of need interpretation:'

Fraser argues that often the most critical phase of political struggle is not around who can influence decisions, but around who can influence the definition of needs. Once there is an understood sense that certain needs exist, solutions are found. The solutions will make sense in terms of the way the needs were defined and in terms of the interpretation given to the needs ...The federal infrastructure program therefore came into being in 1994 because there was an understanding that there was a need for spending on infrastructure $(2002,240$, emphasis added).

As Rochefort and Cobb observed, controversy often surrounds how a given issue will be understood. In this respect the federal response to the 'infrastructure deficit' is no exception.

\section{The FCM shapes the discourse}

Throughout the late 1980 s and the early 1990s, the FCM remained diligent in its battle to secure federal funding for municipal infrastructure. Despite the Conservative government's rejection of its proposal for federal funding, the FCM set out to implement 
a well-calculated strategy to shape political discourse about the infrastructure deficit and the measures that were needed to address it. First it had to navigate around the shoals of constitutional controversy.

Through a concerted lobbying campaign, the FCM was able to secure the support of provincial ministers of municipal affairs and eventually the provincial premiers to call for a new infrastructure program that would involve funding from the three levels of government. As Andrew and Morrison observed, "this allowed the FCM to counteract the (Tory government's) constitutional argument against the proposal by pointing to provincial support" $(1995,110)$. The FCM continued to build support from a coalition of stakeholders that included the construction industry, environmentalists, academics and the engineering community. The Canadian Society for Civil Engineering (CSCE) added their voice to the growing concerns about the state of municipal infrastructure, concluding that the municipal infrastructure debt was $\$ 20$ billion. CSCE's estimate was $\$ 8$ billion or 66 per cent higher than the FCM's estimate of $\$ 12$ billion a year earlier (Vander Ploeg, 9).

After being rebuffed by the Conservative government, the FCM sought political support at the federal level through the Official Opposition. John Turner, the Leader of Opposition, endorsed the FCM's proposal in 1986. The alliance between the FCM and the Liberal Opposition was firmly cemented when the Liberal Party established a National Liberal Task Force on Municipal Infrastructure in 1989 and began a series of hearings across the country. The Task Force survey concluded that a minimum of $\$ 25.1$ billion was required to upgrade municipal infrastructure (David Swimmer, 36).

The Liberal Party's estimate was $\$ 10$ billion higher than that made a year earlier 
by Informetrica Inc. That study had determined that, in addition to current municipal spending on infrastructure, upgrading, replacing and adding new physical core infrastructure would cost $\$ 15$ billion over a five-year period, from 1988-1993 (David Swimmer, 36). However, as Swimmer observed, "the extra \$3 billion per year (called for in Informetrica's review) would increase expenditures on infrastructure by only $5 \%$ per year, raising proportions relative to GDP by $0.4 \%$ to about $3.4 \%$, less than one point above mid-1970 levels" (36). In 1989, the Canada Housing and Mortgage Corporation (CMHC) estimated that $\$ 12.3$ billion was needed to bring municipal infrastructure up to acceptable standards, 40 per cent less than the FCM's revised estimate of $\$ 20$ billion that they produced in 1992 (Vander Ploeg, 9).

Remarkably, there were no challengers who questioned the discrepancy in the various estimates nor were any alternative solutions to the 'problem' put forward other than the FCM's proposal to transfer federal revenues. The various estimates of the infrastructure deficit illustrate vividly Vander Ploeg's observation that "numerous facts and figures are tossed into the public arena where they are often accepted without question"(1). Although there was no clear understanding of what the infrastructure 'debt' or 'deficit' involved, the FCM was nevertheless able to advance its argument that a 'crisis' existed that required a policy solution from the federal government. This would appear to be a good illustration of Rochefort and Cobb's point about the power of employing symbols in language; through their expertise and authority, the FCM coalition was able to gain control over the way the 'infrastructure problem' was perceived and interpreted.

By shaping the political discourse, the FCM coalition was able to control the 
policy agenda: it secured agreement from the Liberal Party Task Force that billions of dollars were needed to 'upgrade' municipal infrastructure. The results of the Liberal Party's Task force were presented at the Liberal Party policy convention in 1991 and were later adopted at the 1992 national party convention. The Liberal's campaign platform in the 1993 election campaign - Creating Opportunity: The Liberal Plan for Canada ('Red Book') - mapped out the objectives that would later drive the public policy rationale for creating the Canada Infrastructure Works Program (CIWP), implemented by the Chrétien government shortly after it assumed power.

\section{The Liberal policy response}

During the election, the Liberals committed to increase government spending in order to stimulate the economy and to restore public confidence, both of which had been battered by a severe recession. Despite a rising $\$ 40$ billion deficit in the federal treasury, a severe drop in federal revenues and increased spending on employment insurance benefits, the Liberals sought to overcome the recession by adjusting monetary and fiscal policies that included increasing federal spending through a new infrastructure program.

The Red Book outlined four objectives for a tri-partite "shared-cost, two-year \$6 billion infrastructure program, to upgrade transportation and local services" (Liberal Party of Canada, 1993, 6). The promised new program would help to create employment rapidly over a two-year period, build infrastructure that "support(ed) economic growth," develop infrastructure that "enhance(ed) community liveability," and demonstrate to the public that the federal government could work cooperatively with other levels of government. Of these four goals, the focus was clearly on creating jobs. The Red Book 
called for an immediate injection of federal spending on local infrastructure as had been done during the Depression and again during the 1960s: "Canadians need jobs now, and strong infrastructure is essential for economic growth an liveable communities" (Liberal Party of Canada, 1993, 60).

\section{Creating Jobs}

During the 1993 federal election campaign, no single issue captured the attention of Canadians as much as the issue of jobs. The general state of the Canadian economy had become very worrisome for most Canadians from coast to coast as a result of high levels of unemployment, uncertain job security for those already employed, and limited opportunities for those about to enter the labour market. Due in large part to the rationalization of Canadian business, a major restructuring of the Canadian economy had triggered the recession after the Canada-United States Free Trade Agreement. Many businesses and factories closed permanently and hundreds of thousands of jobs disappeared. The Canadian economy shrank substantially as real GDP decreased more than 1 per cent, and the unemployment rate rose above 10 per cent in both 1991 and 1992. By 1993, the national rate of unemployment had reached 11.2 per cent, ranging as high as 20.1 per cent in one province (Soberman, vol. 1, 2-3). Even for those in traditionally healthier economic regions, unemployment was a very serious issue.

Championing the need to create instant jobs through the infusion of federal government money in local communities was smart politics, as Andrew and Morrison point out:

The program symbolized a Liberal government's will to act quickly and to be seen as the champion of 'average' Canadians. The Liberals wanted to be seen as pragmatic populists or, at least, to distinguish themselves from the Conservatives who they wished to portray as the defenders of privilege $(1995,112)$. 


\section{Supporting economic growth}

Federal spending in municipal infrastructure was designed to help the construction industry, which had languished during the recession. The recession hit Ontario harder than most areas of the country; the recovery in the province was painfully slow as unemployment continued to increase through the loss of manufacturing jobs resulting from the Free Trade Agreement. The situation worsened after the signing of NATFA. While the Liberals had battled the Tories during the 1988 election about the dangers of free trade, shortly after they assumed power in 1993 they quickly signed on to a broader trade agreement. As Peter Urmetzer notes, "one really has to wonder how sincere the Liberals were when they campaigned against free trade, and one suspects its (sic) position was more based on political opportunism than heart-felt conviction; their subsequent behaviour certainly points in that direction" (108).

According to the Red Book, creating jobs in the construction industry would also help to improve the country's 'international competitiveness:'

Improved transportation and telecommunications systems will contribute to longterm economic growth ...Investing in state-of-the-art infrastructure for Canada will enhance the skills and technological expertise of Canadians, creating development opportunities and domestic markets for such expertise. In addition, the industries developed around this knowledge in areas such as mass transit, telecommunications, and pollution control will help expand Canada's share of work trade by offering innovative goods and services in foreign markets (Liberal Party of Canada, 1993, 60).

Despite the lofty goals that called for investments in 'state-of-the-art infrastructure' and support for the knowledge industry the program was more of a blue-collar job creation program, as Andrew and Morrison observe in their derisively titled chapter, "Canada Infrastructure Works: Between 'Pick and Shovels' and the Information Highway." 


\section{Enhancing Community Liveability}

The Red Book also presented the Liberal policy on sustainable development, a vision that was described as one incorporating "a special physical and spiritual tie to the land" (Liberal Party of Canada, 1993, 64). The Liberals were dismissive of the federal Conservatives' public policy efforts on this issue:

... there is a wide gap between Canada's international rhetoric on sustainable development and its actual domestic policies. For example, although Canada promises to fight climate change, federal policies and funding continue to favour private transportation over public transit, and energy use over energy conservation. A Liberal government will establish a framework in which environmental and economic policy signals point the same way (64).

In the Speech from the Throne opening Parliament on January 17, 1994, the Liberal government expanded on their Red Book commitment: "It will be the policy of the Government to promote sustainable development as an integral component of decision making at all levels of our society" (Canada, 1994, emphasis added). The Liberals later declared in their Foreign Policy Review that sustainable development was as "a central component of the Canadian value system" (Canada, 1994, section V, "Projecting Canadian Values and Culture," emphasis added). While the Liberals had admonished the Conservative government for the wide gap between Canada's international rhetoric on sustainable development and its actual domestic policies, they eventually proved to be equally inept.

The Red Book made the commitment that a Liberal government would change the face of federal policy once elected: "We must aspire to ...take pride in maintaining a healthy, productive Earth," while recognizing that "managing economic development and human growth without destroying the life-support systems of our planet demands of Canadians a fundamental shift in values and public policy" (Liberal Party of Canada, 
1993, 63, emphasis added). The Red Book pointed to two areas of concern where a change in public policy was most needed: water and energy.

The Liberals acknowledged that, "One of the country's biggest sources of water degradation is untreated municipal sewage, aggravated by decades of neglect of sewage and water treatment infrastructure" (67). It was a remarkable observation for them to make since previous Liberal governments had provided over $\$ 2.5$ billion in loans and grants during the 1960 s to assist local governments to improve their water and wastewater facilities as well as other infrastructure. While the Red Book was silent on the issue of who in particular was to blame for the decades of neglect, it championed the promise of a new Liberal government that "would assist provincial, regional, and municipal governments to finance new or renewed municipal sewage and water treatment infrastructure"(67). Federal funding would be conditional, however, reflecting the concerns expressed a few years earlier by federal bureaucrats in the Department of the Environment who had criticized the FCM proposal during the mid 1980s for its failure to address the need for more rational policies of water management. The Red Book stated that, "this federal commitment would be conditional on municipalities encouraging water conservation and developing a sound financial regime for infrastructure maintenance in the future" (67, emphasis added).

The second area of environmental concern identified by the Red Book involved the need for increased energy efficiency, which "is widely recognized to have the largest potential for short-term contributions to sustainable development." The Red Book presented the commitment that, "As part of its sustainable energy strategy, a Liberal government will use the means at its disposal to support a shift towards energy efficiency 
as a first step, and a transition towards a more sustainable mix of energy sources in the longer term" (67, emphasis added).

While providing federal funding for municipal infrastructure would afford opportunities to introduce more sustainable practices in municipal infrastructure planning and development, the Liberal policy on sustainable development outlined in both the Red Book and the Chrétien government's first Speech from the Throne did not survive the transition from print to practice. With the need to address water degradation, increased energy efficiency, and improved infrastructure maintenance, it could be assumed that these issues would be included as major components of the proposed new municipal infrastructure program. Unfortunately, such an assumption would be wrong. Despite being a potential vehicle to initiate a major shift in public policy, the new program was more about job creation - picks and shovels - than sustainable development.

\section{Intergovernmental Cooperation}

The Red Book promoted the idea that a tri-partite funded infrastructure program would build cooperation among the three levels of government. A new infrastructure program would provide a contrast to the intergovernmental squabbling during the failed Meech Lake and Charlottetown Accords, casualties of the divisive efforts to amend the Constitution that severely undermined the credibility of the federal government. A jointly administered program would provide the means to demonstrate that the federal government could work cooperatively with other levels of government.

The new infrastructure program was also supposed to be a demonstration of the Liberal Party's view of the role of government. The Liberals saw government as a necessary positive force that helped to steer the market. As the Red Book stated, the 
federal government's role was "to work with the private sector to clarify strategic opportunities for the future, then to redirect its existing resources towards the fulfilment of these opportunities ..." (Liberal Party of Canada, 1993, 44). In other words, as Andrew and Morrison point out, the Liberals were acknowledging that the role of government had to change:

Governments should act to assist the private sector; they should help set up a framework for activity rather than acting directly. Building and upgrading infrastructure fits well within this general model of state action because it facilitates the actions of other parties rather than being the central actor itself $(1995,113)$.

The Liberal view that government should concern itself with 'frameworks' rather than direct intervention would eventually change, however, as would later be evident in the subsidies provided by the federal government to tourism and professional sports-related projects that received fundings through its infrastructure programs.

\section{The Canada Infrastructure Works Program (1994-1999)}

Following their election victory in $1993,{ }^{27}$ the Liberal government moved quickly to launch the new municipal infrastructure program. Art Eggleton was appointed President of the Treasury Board and Minister responsible for Infrastructure. As Toronto's former mayor, he was also well connected to the FCM. There was no need to begin a complicated intergovernmental consultation, which would have slowed the implementation process. Since the FCM had done much of the groundwork before the election, the concept of a tripartite infrastructure program had already been discussed and

\footnotetext{
${ }^{27}$ The 1993 election provided the Liberals with a majority government (177 seats) and represented an unprecedented loss of seats (as well as popular vote) for the ruling Conservatives: they fell from 169 seats to 2 seats in the House of Commons.
} 
the major stakeholders had agreed to it - the provinces were already onside (Andrew and Morrison, 1995, 112).

The Canada Infrastructure Works Program was launched soon after a meeting of First Ministers in December 1993. Given the political direction to implement the program quickly in order to start the flow of federal cash and create jobs, the policy development for the new program was built on Red Book commitments. ${ }^{28}$ Consequently, the new Liberal government was anxious for a quick ramp up of the program. There was no need for the public service to present alternative policy approaches, nor was there any requirement to consider whether a more targeted approach to federal spending would offer better results.

The federal government expected the other two levels of government to both match (and perhaps exceed) its $\$ 2$ billion contribution. Using a formula that combined population and the rate of unemployment, federal funds were allocated to the provinces, territories and to First Nations. ${ }^{29}$ While the program was initially intended to be shortlived (two years), it was eventually extended by one year. In 1997, a second phase of federal funding added another $\$ 400$ million (matched by the other governments), which was allocated over two more years.

\section{Program Design}

By early 1994, most provincial and territorial governments had signed contribution agreements with the federal government. Under these arrangements, the

\footnotetext{
${ }^{28}$ The Red Books used by the Liberal Party in federal election campaigns presented political commitments that morphed into policies to be taken as gospel by the federal public service. Consequently, the role of the public service became very much focused on obedience or compliance with policy that was already developed from the machinery of politics, rather than offering a 'professional' challenge function that sought to provide better public policy advice that gave due consideration to alternative approaches.

${ }_{29}$ The federal government provided a portion of its funding to assist First Nations on reserve, administered by Indian and Northern Affairs Canada.
} 
federal government would contribute one third of the eligible costs of approved projects, the remaining two thirds being the responsibility of provincial and municipal governments or other local organizations. The agreements were detailed contracts that set out the program's purpose, criteria for project selection, and the financial and operational responsibilities of the parties involved. Unlike grants, contributions are subject to considerable administrative oversight. ${ }^{30}$ As the Auditor General later observed, "this was the first time that such a framework had been established for a major infrastructure initiative by the federal government" (Auditor General of Canada, 1996, para. 26.18).

The responsibilities of the federal and provincial governments were exercised through a joint federal-provincial/territorial management committee established in each jurisdiction. Public servants were appointed by their respective ministers to carry out this role. While the provinces were responsible for selecting, analysing and proposing projects that would be considered for joint funding, the agreements provided the federal government "with an influential role in establishing criteria and guidelines for project selection" (Auditor General of Canada, 1996, para. 26.19). Although it was rarely exercised, the federal government also had the right to approve or reject individual projects that were proposed. As the Auditor General observed, "it was appropriate that the federal government not become involved in project nomination or in 'second guessing' the decisions made by the other levels of government on screening and selecting from initial project proposals" (1996, para. 26.29).

\footnotetext{
${ }^{30}$ The federal Treasury Board states that payments made by the federal government as 'contributions' to recipients must satisfy conditions relating to performance and achievement. Further, they are subject to audit to satisfy that all conditions - financial and non-financial - are met. Grants, on the other hand, are not subject to being accounted for or audited although eligibility and entitlement may be verified or the recipient may need to meet pre-conditions.
} 
The federal-provincial/territorial agreements established the framework for implementing the program and were complemented by contractual arrangements between provincial/territorial governments and each project proponent. While the latter were mainly municipal governments, there were some instances of projects that involved nongovernmental organizations (NGOs) and private sector participants. ${ }^{31}$ The arrangements were specific to each project and dealt with such matters as project proposals, eligible costs, funding limits, the letting of contracts and project implementation. Contribution agreements between the senior levels of government spawned thousands of contribution agreements with local governments for funding their capital projects.

The administrative arrangements prescribed by the federal government described by the Auditor General as "complex" - would later serve as a template for subsequent federal infrastructure programs (1996, para. 26.42). The process relating to the approval of federal funding under CIWP was highly incongruous: the President of the Treasury Board and Minister responsible for the program approved the federal funding for every project, from a $\$ 107$ share of a picnic table in Alberta to $\$ 60$ million for a Trade Centre in Toronto. ${ }^{32}$ By the end of the CIWP in 1999, nearly 17,000 projects received funding. The Liberal government claimed that nearly $\$ 2.4$ billion in federal funding for these projects had leveraged nearly $\$ 6$ billion in additional spending from the other levels of government and created over 100,000 short-term jobs. However, both the Auditor General and the federal government's own evaluator of the program challenged

\footnotetext{
${ }^{31}$ For example, Gaz Mètropolitan received nearly $\$ 17$ million from the federal government for the expansion of its gas distribution network in Quebec; slightly over \$6.2 million went to Manitoba for the expansion of the gas system. Professional sports facilities and tourist operations also received federal funding.

${ }^{32}$ The Minister would receive lists of projects containing minimal information, which was identified as a concern in the Auditor General's 1996 and 1999 Reports on the program.
} 
claims about CIWP's achievements.

\section{Auditor General's Observations}

The Auditor General carried out an audit of CIWP in 1996 and conducted a follow up audit on the program in 1999. The 1999 Report acknowledged that the CIWP "contributed to positive federal-provincial relations" and pointed to the efforts made to ensuring that participation of all partners was recognized. The Report noted that the federal-provincial/territorial agreements "provided for the careful co-ordination of joint public announcements and the posting of signs identifying projects as joint federalprovincial ventures (and that) subsequently, considerable administrative effort was directed to ensuring that these provisions were carried out" (1999, para. 17.38).

The Auditor General lauded the measures taken by the federal government to recognize the partners' efforts and the degree to which this 'helped foster positive relationships." However, the federal government's interest in the communications aspects of the program was not entirely altruistic. The Liberal government recognized the power in advertising the federal presence in local communities across the country. As a condition for receiving federal funding for their projects, municipalities were required to post signs at construction sites that identified the source of tri-partite funding. Even after construction ended, these signs often continued to serve as backdrops for the Liberal government's promises during subsequent election campaigns, providing testimony that the Liberals had delivered on their to promise to provide cash for municipal infrastructure. $^{33}$

While applauding the co-ordination of joint public announcements, the Auditor General found that the basic focus of the program set out in the agreements with the

\footnotetext{
${ }^{33}$ The signage served local politicians as well, providing proof that they had landed money from Ottawa.
} 
provinces and territories was very problematic: "We identified problems in the framework for achieving program objectives, including a lack of clarity in the criteria for project selection and in the intended overall coverage of the program" (1996, para.

26.35). In other words, what the Auditor General identified as a "range of objectives" for the program - economic recovery, upgraded infrastructure, employment creation, skills development, enhanced economic competitiveness, and improved environmental quality - provided no focus for federal funding. The lack of targeting in the program was most evident in the vague criteria used to assess projects that purported to upgrade the quality of Canada's physical infrastructure in local communities (the program's 'raison d'être'):'

The requirement to bring infrastructure up to community standards ...is among the most important of the project selection criteria in the federal-provincial agreements. It relates directly to the achievement of one of the central objectives of the program. However, the federal-provincial agreements give no indication of what the term "community standards" actually means or how these standards should be identified ... While individual community standards are for local communities and provinces to determine, we had expected to see an approach that would target scarce program resources where they were needed most. What we found was that many approved project proposals did not contain adequate analyses of infrastructure needs. (1996, Para 26.36 and 38, emphasis added).

The observations from the Auditor General cogently summarized the basic flaw in the program's policy framework. Neither the provinces nor the federal government intended to direct scarce resources to where they were most needed. Rather, the essential purpose of the program was to transfer federal and provincial resources to local governments as quickly as possible, regardless of need. The absence of any requirement to present a justification of the need and priority for funding in project proposals underscored the message to municipal applicants that they only had to spend program funds on some type of municipal infrastructure. 
While finding it impossible to gauge the program's degree of success in upgrading the quality of municipal infrastructure, the Auditor General found it equally daunting to determine the degree to which the program had been able to 'enhance economic competitiveness.' The criterion was not clearly defined in federalprovincial/territorial agreements:

'Enhancing economic competitiveness' ranged from improving economic efficiency (for example, through improved roadways) to supporting the development of local parks that would make municipalities more attractive places to live. The latter is a quite different interpretation of competitiveness that involves a much longer-term, indirect effect that may or may not occur (1996, Para 26.39).

In addition to having difficulties in determining how 'economic competitiveness' was measured under the program, the Auditor General was suspect of the Liberal government's claim that the program had leveraged $\$ 6$ billion in new funding from the other partners. The 1996 Report pointed out that CIWP was expected to generate additional investment activity in municipal capital works activities: "In other words, it was expected to result in infrastructure investments over and above those that would have been made in its absence ... additional investment effects are of central concern because they are directly tied to the issue of whether the program has made a difference and, if so, to what extent" (1996, para. 26.52).

The Auditor General reasoned that, if federal funding was directed to pay for part of the costs of a municipal capital project that have would proceeded even in the absence of program funding, "then the program would produce no net infrastructure benefits; nor would it create additional employment." The Auditor General questioned the 
'incrementality' ${ }^{34}$ of many of the projects funded under CIWP, stating that 35 per cent of the federal expenditures during the first year of the program had replaced "normal local capital spending." The Auditor General pointed out that the confusion in determining incremental investment extended beyond the level of a given project to the level of the total capital budget as well:

...there is a need to clarify further whether the predetermined level of investment required for a municipality to be eligible for program support should relate only to the municipality's own investment expenditures or to the total capital investment (including other government subsidies) in its infrastructure (1996, para. 26.65).

In the Auditor General's follow-up 1999 Report on the program, concerns were also expressed about the 'substitution effect' of federal spending. While provincial and territorial governments have traditionally provided ongoing financial support to municipalities for local infrastructure investment, the federal funding under the CIWP provided provinces with the opportunity to reduce their funding for their own programs for assisting municipal capital works projects. Rather than increasing their funding, they redirected provincial dollars towards the tri-partite program with the federal government:

The period during which the program functioned featured a lot of general budget cuts by provincial governments, including cuts in provincial capital assistance programs. At the same time, however, the federal initiative was attempting to increase levels of infrastructure investment. In this context, substitution would represent a rational response by provinces to the national infrastructure program (1999, para 17.62, emphasis added).

The Auditor General also challenged the federal government's estimates of employment created by the program. When the program was launched in 1994, the federal government estimated that its investments in municipal infrastructure would create approximately 100,000 short-term jobs during construction and an additional 9,200

\footnotetext{
${ }^{34}$ Incrementality at the project level is defined as additional investment during a particular period when the program funding leads to an investment that would not have occurred otherwise or would accelerate what was planned in current capital plans.
} 
longer-term jobs once the new infrastructure was put in place (1996, para. 26.98). The federal government relied on those receiving program funds for a project to provide an estimate of jobs created; as well, an economic 'input-output' model ${ }^{35}$ was used to estimate the jobs created (1996, para. 26.100).

The question raised by the Auditor General about the reliability of the federal government's estimate of employment generated by CIWP was of particular concern. Job creation was a critical measure of the degree to which the program had achieved one of its key objectives. In the 1999 Report, the Auditor General chastised the federal government for the lack of rigour in verifying program results, concluding that CIWP was "essentially 'running on trust' with little confirmation that performance conditions (were) being met" (1999, para. 17.104).

The Auditor General also observed that the federal government's commitment to using CIWP to "promote improved environmental quality, including the introduction of environmentally sustainable practices and technologies," was unclear. As was the case with other program objectives, supporting the principles of 'sustainable development' was part of a list of good intentions that lacked a reasonable means of measurement and accountability for results.

\section{Program Evaluation}

In "Taking Stock: A Review of the Canadian Infrastructure Works Program," Richard Soberman - an academic with the University of Toronto's Department of Civil

\footnotetext{
${ }^{35}$ The estimate of the short-term employment is derived from Statistics Canada's data on employment effects associated with given levels of investment. The Statistics Canada figures are based on the historical track record of investment expenditures in generating direct employment, both on-site (where the infrastructure is being developed or upgraded) and off-site (supplies and services provided).
} 
Engineering - outlined his assessment of the program. ${ }^{36}$ The report was prepared for the President of the Treasury Board and Minister responsible for Infrastructure, in keeping with the requirements of the Financial Administration Act. Soberman agreed with the Auditor General's finding that the program enjoyed widespread popularity in municipalities and most provinces. Local governments were very pleased to spend '33cent dollars' for their infrastructure investments. While he concluded that, "the condition of municipal infrastructure was appreciably improved," there is some question as to what infrastructure was involved (vol. 1, ii).

The original rationale put forward by the FCM was based on the need for funding from senior levels of government to address the 'infrastructure deficit' - the shortfall in bringing existing infrastructure up to standards. The policy framework supporting the injection of federal funds into municipal infrastructure was based on the need to take immediate action to prevent the deterioration of the existing capital stock and the concomitant risk of substantial longer-term costs. An examination of the data for CIWP reveals some interesting results: less than one-third of program funds was directed to water and sewer assets, of which more than half was used for new or expanded infrastructure; of the eleven per cent of program funds used for 'community, cultural and recreational facilities,' over sixty per cent was used for new or expanded infrastructure; of the six per cent of program funds used for 'municipal buildings,' sixty per cent was applied to the construction of new or expanded facilities. Only the funding for roads and bridges, which received one-third of program funds, was targeted largely to deal with the

\footnotetext{
${ }^{36}$ Soberman employed an impressive methodology that included: analysis of the CIWP data base; case studies of municipal projects; special studies that estimated economic impacts; a Delphi panel composed of recognized economic experts and program stakeholders; and a survey of those involved in administering the program.
} 
repair of existing assets ( 87 per cent). ${ }^{37}$ However, given the need to distribute program funding to as many communities as possible, it is not surprising that many municipalities used whatever federal and provincial funding they could get to undertake small road projects of the 'shave and pave' variety. As well, local politicians recognize that road repair projects provide them with more political mileage than many other types of less visible infrastructure projects.

The federal government's decision to fund municipal infrastructure renewal as a mechanism for employment creation was driven primarily by the belief that municipal infrastructure in Canada was badly in need of major repair and rehabilitation. The FCM had convinced the Liberals before they assumed office that the existing deficiency in municipal infrastructure was due to a lack of sufficient funding to keep pace with needed repair. As Soberman observed, "local priorities clearly have placed the requirements of new growth and expansion ahead of needs to repair existing facilities" (vol. 1, 6). As a consequence, the municipalities had undermined the basic rationale for federal funding, "raising serious doubts as to the credibility of the estimated magnitude of the real municipal infrastructure deficit. Municipalities argued strongly for assistance to deal with decaying infrastructure and then used most of the money for system expansion" (vol. 1, ii, Original emphasis).

Municipal governments applied for funding from CIWP much in the same way as they had during earlier federal infrastructure programs that had focussed on building more water and wastewater treatment infrastructure to respond to population growth in the suburbs. When presenting their priorities to CIWP for funding major new facilities, local governments justified the need based on the deficiency of existing infrastructure to

\footnotetext{
${ }^{37}$ CIWP database, Infrastructure Canada.
} 
handle the greater capacity needed for anticipated growth in demand (vol. 1, 25). As Soberman points out, local politicians were more interested in constructing high visibility projects such as community centres and sports facilities rather than focusing on repair and maintenance:

...ribbon-cutting is almost always a preferable political activity to filling potholes or repairing underground water mains, at least in terms of media exposure. As a result, elected officials have a preoccupation with engaging in new projects that have a clearly identifiable constituency, such as land developers, at least in relation to the silent majority of those who now use existing systems (vol. 1, 25).

Dealing with problems of maintenance and rehabilitation was not as politically attractive, even though, as Soberman observed, "in many communities, the quality of infrastructure borders on a deplorable state as, for example, in communities that in this day and age are unable to maintain acceptable drinking water standards" (vol. 1, 25).

Soberman's observations about the level of incremental spending involved in CIWP closely paralleled those of the Auditor General. When the program began, project proponents were expected to attest to the incrementality of their project by making a declaration that the project could not have proceeded without the injection of CIWP funding. However, Soberman found that:

(Except for Quebec) there appears to have been little serious effort to enforce this program requirement. Nation-wide, the level of incrementality achieved cannot be determined with a high degree of certainty ...federal contributions were not intended to merely substitute for funds that would otherwise have been invested by the provincial and municipal governments" (vol. 1, ii).

Soberman recognized that the original policy rationale behind CIWP was suspect, since any expectation that municipalities would increase their capital spending in times of declining provincial and municipal budgets - and cuts to federal transfer payments - was pure folly. Expecting incremental investment from local governments was wishful 
thinking since they were "faced with strong pressure to avoid even the most minimal increase in property taxes - their principal source of revenue - (and consequently were) more likely to alter their priorities for spending to gain the leverage afforded by the CIWP, without necessarily increasing overall spending" (vol. 1, 31, original emphasis).

Soberman's observation about the absence of incremental investment at the local level was also aimed at the federal government. He noted that the impact of government spending on the economy is dependent on the nature of the investment as well as the source of funds used. In the case of CIWP, funds were redirected from a spending commitment made by the previous Tory government: “...in the 1993 election platform summarized in the Red Book, it was indicated that the Infrastructure Program would be financed from (the) cancellation of previously approved expenditures, notably the military helicopter program" (vol. 1, 31, footnote 5). This point was further reinforced by the observations made by the economists participating in Soberman's Delphi Panel who noted that, "If the program only reallocates (federal) spending, then there would be an employment impact only if CIWP expenditures are more labour-intensive than the displaced expenditures" (Vol. 2, 9).

The federal government's.approach to allocating its funding for CIWP was also problematic from a public policy perspective. Rather than targeting its funding to maximize benefits in those areas of the country that were most affected by the FTAinduced recession - particularly urban areas in Ontario and Quebec - the federal government decided to use an allocation formula for transferring funds that would be more politically neutral. A formula combining the rate of unemployment with population would be perceived as fair to all provinces and territories. As Soberman pointed out, 
however, if the primary objectives of the program were based on addressing unemployment and fixing the problems of infrastructure, applying fairness in the allocation of program funds doesn't work:

... such an approach does not necessarily reflect the real disparity in actual infrastructure needs that one might expect to find across the entire country. Provinces do differ in the composition, quality and quantity of local infrastructure, and for this reason 'equal' treatment is not necessarily synonymous with 'equitable' treatment. Under a population based allocation formula, a facility improvement in one jurisdiction may be funded even though it is less in need of repair than a similar facility elsewhere (Vol. 2, 9).

Using fairness as the basis for allocating federal funds ignores the fact that the weakness in the economy was not felt evenly across the country. ${ }^{38}$ As well, under the administrative rules for CIWP, some municipalities were allowed to use their own personnel and equipment in undertaking their infrastructure projects. As a consequence, these projects had no impact on the local construction industry as no new jobs were created. What was more important for the Liberal government was the effect of 'sprinkling' federal funding to ridings across the country in order to reap the ensuing political rewards.

Another observation made by Soberman is equally instructive. While the primary policy rational for the CIWP was based on the macro-economic impact of public expenditure - quickly creating jobs in the construction sector - the federal government also claimed that the funding would address longer-term structural issues in the economy. Investments in projects funded through CIWP were expected to assist in upgrading and maintaining worker skills, and lead to the development of new technologies, thereby improving Canadian competitiveness. The federal government's rationale for investing

\footnotetext{
${ }^{38}$ See Thomas Wilson et al, "Sources of the Recession in Canada: 1989-92," Canadian Business Economics, Winter 1994.
} 
in infrastructure was based on the so-called Aschauer effect - that is, the belief that public investment leads to gains in private sector productivity, thereby improving competitiveness in global markets. The Red Book championed the concept of investing in "state-of-the-art infrastructure" that would enhance the skills and technological expertise of Canada's workforce, "creating development opportunities and domestic markets for such expertise." However, Soberman's evaluation of CIWP concluded otherwise:

the magnitude of the direct relationship between public infrastructure and private productivity cannot be determined for the CIWP with any degree of authority ... there is not much to distinguish between the CIWP and debt reduction from the standpoint of long term productivity ... as an argument in support of CIWP, improved Canadian competitiveness carries little weight from the point of view of the economy as a whole (vol. 1, 66-67, Emphasis added).

One other observation from Soberman's evaluation of CIWP was particularly disturbing. He concluded that, as a general practice, transferring funds from senior levels of government to local governments sends the wrong pricing signals, resulting in what economists refer to as sub-optimal decisions or 'rent-seeking' (vol. 1, 67). 'Rentseeking' behaviour occurs when municipalities attempt to maximize leverage from shared-cost programs, a practice that was already common in provincial subsidy programs for capital investment in roads and transit. Policies that produce subsidies and programs that transfer funds tend to mask real costs, thereby "introduc(ing) distortions in the decision-making process which favour capital-intensive alternatives such as new construction or the acquisition of new equipment over less capital-intensive solutions involving maintenance and repair" (vol. 1, 26).

Soberman's remarks closely paralleled those made during the mid 1980s by 
officials in the federal Department of the Environment who had advised the Conservative government against supporting the FCM's proposal for municipal infrastructure funding. Citing the work of Gillen and Waters ${ }^{39}$ on infrastructure investment and economic development, Soberman stated:

... it can be argued that subsidizing capital encourages capacity expansion (and sprawl) rather than more efficient use of existing facilities. In other words, a growing body of opinion supports the notion 'that efficient pricing policies would enable much better performance from existing infrastructure' as compared, presumably, to capital investment to meet improperly priced growth in demand" (vol. 1, 29).

As with provincial and territorial infrastructure subsidy programs, Soberman found that CIWP masked the real costs of capital investments in municipalities.

Consequently, "the CIWP is likely to have delayed the introduction of efficient pricing, demand management, and technological innovation, now widely accepted as a more effective long term means of dealing with deficiencies than capital expansion" (vol. 1, 67). Soberman concluded in his advice to the President of the Treasury Board and Minister responsible for Infrastructure that, "it is not clear that this particular shared funding initiative should become a permanent federal government program" (vol. 1, 2). Harry Kitchen arrived at the same conclusion in his own critique of CIWP, and encouraged "greater political and economic debate over the merits of this or comparable programs that may be initiated in the future" $(1995,16)$.

A few months after the Minister received Soberman's report, the Liberal government decided to add another $\$ 400$ million as the federal share of a second phase of funding for CIWP. The agreements with the provinces and territories were signed very

\footnotetext{
${ }^{39}$ David W. Gillen and W.G. Waters II, eds. "Introduction, Transportation Infrastructure Investment and Economic Development", The Logistics and Transportation Review, Special Edition, Vol. 32, No. 1, (March 1996).
} 
quickly, shortly before the federal election in June 1997. Although the additional funding for CIWP was intended to be limited to one year, following pressure from local governments who flooded the minister's office with a letter campaign, ${ }^{40}$ the program was eventually extended to two years. While CIWP officially concluded in 1999, a few projects were completed during the following two years.

Of particular note during the second phase of CIWP, a significant effort was made to ensure that federal funding was given sufficient visibility when projects were announced, on signage during construction, and at ribbon-cutting ceremonies at project completion. Federal representatives on the management committees established to administer the program in each jurisdiction were required to ensure that 'federal visibility' would improve during the second phase of funding. Each of the federal ministries supporting program delivery ${ }^{41}$ were required to provide a communications function that coordinated activities about projects - especially media events - with the offices of government MPs.

Two issues drove the federal government's communications agenda: the 'near death' experience during the Referendum debacle in 1995; and the diminished presence of the federal government locally following Program Review. ${ }^{42}$ During the second phase of CIWP as well as for all infrastructure programs that followed, federal visibility and

\footnotetext{
${ }^{40}$ Given the lengthy process to obtain funding approval for projects, municipalities complained that a oneyear 'top-up' of the program was far too short to accommodate the construction season. However, the extension triggered a new round of federal-provincial/territorial agreements that amended those signed in early 1997. As the Auditor General observed, the administration of the program was 'complex.'

${ }^{41}$ The federal ministries involved in CIWP and subsequent infrastructure programs included Western Economic Development, Industry Canada (for Ontario), Canada Economic Development for the regions of Quebec, the Atlantic Canada Opportunities Agency, and Indian and Northern Affairs Canada (for First Nations communities in the provinces, the Yukon, the Northwest Territories and, after April 1999, Nunavut).

${ }_{42}$ In 1993-94, Canada's deficit and level of indebtedness were the second highest among the seven largest industrial countries (the G-7). In order to address this, the government established firm and binding fiscal targets (reductions) for the next two years. Program Review was part of this process, which compelled all ministers and senior officials to subject all the programs and activities they delivered to tough scrutiny.
} 
how to promote and exploit it politically became a very significant focus of program administration. In this respect, the infrastructure programs and the infamous Sponsorship Program share a lot of common ground.

The preoccupation with creating blue-collar jobs through infrastructure investments had largely disappeared from the Liberal platform (Red Book II) during the 1997 election. The Liberals were now advocating more strategic investments in infrastructure:

While economic conditions favourable to healthy-private-sector job creation are now in place, the federal government must continue to invest in key sectors of the economy, in partnership with the private sector and other governments, to ensure that as many jobs as possible are created and that economic growth is strong ... The next Liberal government will continue to make strategic investments in ... infrastructure ... investments that pay dividends in jobs and growth in both the short term and the long term" (Liberal Party of Canada, 1997, 31).

The proposed strategic investments in infrastructure - "from the roads we drive on to the information highway that links us to the world" - would benefit the national economy. "Improvements to the community assets" would include those " that business needs to be competitive and enhances the quality of life in our communities, as well as creating work for thousands of people" $(1997,43)$. While calling for 'strategic' investments, the agreements with the provinces and territories for the second phase of CIWP funding had already been signed. As with the first phase of the program, Phase II was not strategic from a public policy perspective. ${ }^{43}$

The bonhomie between the Liberal government and the provinces during the early

\footnotetext{
${ }^{43}$ Federal infrastructure funding for a convention centre in Shawinigan and ski hill developments in Mount Tremblant were politically driven, rather than policy-driven. It is interesting to note that the 1997 Budget had provisions that included "a tourism financing vehicle to be administered by the Business Development Bank of Canada and financed through $\$ 50$ million in new equity." The Budget had specified that, "This new financing arm will operate on a commercial basis and will offer loans for expansions or upgrades of tourism facilities outside major urban centres." CIWP funding did not operate on a commercial basis.
} 
days of CIWP had also radically changed, particularly with the governments of Quebec and Ontario following the election of the Parti Québécois in 1994 and the Harris

Conservatives in 1995. Both insisted during negotiations for Phase II funding that the federal government's role in municipal infrastructure should be limited to cutting cheques for the provinces. In Quebec, especially, the province's role as the maitre d'oeuvre in administering the infrastructure program was sacrosanct. In order to get both provinces to sign before the election writ was dropped in 1997 , the federal government caved in to demands to include provincial assets as eligible projects for funding under the agreements. The Harris government had railed against the federal Liberal government's decision in 1995 to drastically cut transfer payments; it was adamant that provincial priorities - highways, medical care facilities and education facilities - would receive the bulk of federal funding under Phase II. ${ }^{44}$ The Association of the Municipalities of Ontario (AMO) as well as its members were not impressed to see a significant portion of 'their money' diverted to provincial assets.

During the dying days of CIWP, the FCM and La Coalition pour le renouvellement des infrastructures du Québec lobbied the federal government to renew its funding for municipal infrastructure. The FCM encouraged its member municipalities to issue resolutions calling for a new program, and to acknowledge the successes of the CIWP. Municipal resolutions clearly indicated that the FCM had the political property rights not only to the need for more funding - it also 'owned' the concept of tripartite funding for infrastructure. Despite observations from the Auditor General and Soberman

\footnotetext{
${ }^{44}$ Relations between Ottawa and Queen's Park were markedly testy. The Liberals had infuriated the Harris Conservatives during the election campaign when a federal Minister in the GTA made campaign promises to spend infrastructure money on assets not covered in the recently signed CIWP Phase II agreement. The harangue was in the media for months until a deal was struck that allowed the federal government to fund some projects without any provincial contribution.
} 
that questioned the authenticity of the results attributed to the program, many resolutions nevertheless referred to the "FCM-inspired \$8.3 billion, six year Canada Infrastructure Works Program (CIWP) ...(which) exceeded original projections, funding 17,000 projects that created assets of lasting value and generated more than 130,000 short term jobs, and set a new standard for intergovernmental cooperation in Canada." ${ }^{45}$ The FCM also reminded the Prime Minister of the observations he made when he addressed the FCM during its Annual Conference. He had praised CIWP as "one of the proudest achievements of our governments. And one of the things I am personally most proud of. You can see the results at work all across Canada" (Chrétien, 1998). With this endorsement behind them, the FCM and La Coalition pour le renouvellement des infrastructures du Québec launched a concerted effort to get the Liberal government to spend even more federal cash on municipal infrastructure.

\section{The Infrastructure Canada Program (2000-2007)}

The rationale for more federal funding for municipal infrastructure could no longer be justified by the need to create construction jobs. By 1999, the national economy had recovered, surpassing forecasters' expectations. The unemployment rate was down to 6.8 per cent, its lowest level in nearly 24 years. In the Speech from the Throne (SFT), the federal government now turned its attention to investing in "infrastructure for the 21st Century:"

\footnotetext{
${ }^{45}$ An example of the typical municipal resolution at the time can be found at the City of Vancouver's website, http://www.city.vancouver.bc.ca/CTYCLERK/CCLERK/990622/a4.htm The concerns expressed by the Auditor General of Canada about the accuracy of the job count were notably absent.
} 
For Canada to generate jobs, growth and wealth, it must have a leading, knowledge-based economy that creates new ideas and puts them to work for Canadians. To do this, it is essential to connect Canadians to each other ... Achieving this objective will require new types of infrastructure (Canada, 1999).

The Liberal government committed to making investments in transportation-related infrastructure that would ensure "the capacity to move people and goods safely and efficiently" in order to increase trade and economic growth. As well, the government acknowledged that work was needed "to maintain the quality of life" in urban and rural areas, in particular clean air and water.

The SFT announced the government's intention to reach agreement with other levels of government and the private sector on "a five-year plan for improving physical infrastructure in urban and rural regions across the country." The federal government expected that "all partners (would) increase their resources directed toward infrastructure ...focus(ing) on areas such as transport, tourism, telecommunications, culture, health and safety, and the environment." The SFT also outlined a commitment to address the "quality of our environment," stating that the federal government "will place greater emphasis on sustainable development in government decision making." The challenge, of course, was to see how these commitments could be implemented in another municipal infrastructure program.

The FCM had lobbied hard for a long-term national infrastructure program that would provide environmental benefits through a "sustainable communities strategy." Improving the "quality of life" in municipalities was now the axiom of choice. In May 1999, the FCM had published its Quality of Life Reporting System, which was intended to help "identify and raise awareness of issues affecting quality of life in Canadian communities (and) better target policies and resources aimed at improving quality of life" 
$(1999,1)$. The framework also had a more important political agenda: it was part of the FCM's strategy to "establish municipal governments as a strong and legitimate partner in public policy debate in Canada" $(1999,1)$.

In its proposal submitted to the Minister of Finance for the federal Millennium Budget, the FCM claimed that, while CIWP had provided positive benefits to municipalities, the program "could not fully address Canada's long term infrastructure needs" (emphasis added). There were still "a number of outstanding infrastructure projects which (local governments could not) finance out of municipal revenues alone." The FCM claimed that the new long-term national "core municipal infrastructure program" would provide a myriad of benefits: reducing pollution; saving taxpayers money resulting from reduced health and environmental damage; creating jobs, improving the efficiency of the economy; and making Canada more competitive, productive and innovative. The Liberal government again accepted the FCM's rationale for more funding for infrastructure, although the range of infrastructure funded under the new program would involve much more than that which was 'green.' 46

The theme for Budget 2000 very much centred on "making Canada's economy more innovative." As well as providing significant investments in innovation, knowledge and skills (an additional $\$ 900$ million was provided for the Canada Foundation for Innovation), the Budget allocated $\$ 700$ million for the promotion of environmental technologies and practices. A total of $\$ 2.65$ billion was also allocated to a new Physical Infrastructure Initiative that would "(strengthen) the basic physical infrastructure which underpins so much of the economic activity of both rural and urban Canada" (Canada,

\footnotetext{
${ }^{46}$ The federal government defined 'green municipal infrastructure' as projects that improved the quality of the environment and contributed to national goals of clean air and water.
} 
2000). The Budget Speech committed the government to making improvements to municipal infrastructure that would lead to broad economic benefits:

... an innovative economy will not function without basic physical infrastructure that supports municipal services and allows people and goods to be moved safely and quickly. To that end, all orders of government share in the responsibility to renew Canada's infrastructure and find ways to increase its efficiency (Canada, 2000).

The largest share of new federal funding for physical infrastructure (\$2.05 billion) was directed to a new municipal infrastructure program, while the remaining $\$ 600$ million was allocated to a new highway program. The Minister of Finance stated that the Government would "work with other orders of government and, where applicable, the private sector to reach agreement on a plan to improve provincial and municipal infrastructure in cities and rural communities across Canada" (Canada, 2000). While hinting that the private sector would be consulted in the design of the new program, the actual consultation process involved the same players as those during CIWP.

Ontario and Quebec applied the same strategy in their negotiations with the federal government as had occurred during discussions to add a second phase of federal funding to CIWP. Both provinces delayed the negotiations on their agreements with the federal government well into the autumn of 2000 , sensing that the Liberal government was anxious to see the agreements concluded before the drop of the federal election writ. For both provinces, like the homily - 'All good things come to he who waits' - they waited patiently to ensure that the terms of the agreement would restrict the federal government from dealing directly with their municipal governments. There would be no shared administration of the program in Ontario and Quebec; the provincial governments 
would act as the sole conduits for project proposals from municipalities. ${ }^{47}$

Under the terms of each agreement, Ontario and Quebec would present the federal government with their priorities for infrastructure projects. In Ontario, municipalities were required to apply for funding through existing provincial programs and identify in their applications to the province whether they were also seeking funding for their projects from the federal government. The process later proved intensely frustrating to Liberal MPs in Ontario, who were annoyed that they were required to refer their constituents to one of the Harris government's infrastructure programs if they were seeking matching federal funds. ${ }^{48}$

Ontario and Quebec were the last jurisdictions to conclude their agreements with the federal government, which were signed on October 20,2000. The federal election campaign started shortly after the signing ceremonies; the election was held on November 27, 2000. As had occurred during the 1997 election, the federal Liberals campaigned on their ability to deliver more federal funding for municipal infrastructure. In "Healthy People, Healthy Environment" -- Chapter 2 of Red Book III - the Liberals championed the new focus of 'green' investments that would occur as a result of the recently launched Infrastructure Canada Program (ICP):

A new Liberal government will fund improvements to municipal water and wastewater systems through the federal-provincial municipal Infrastructure Canada program ... (and) will work with the provinces, territories, and municipal governments to create the first building code for municipal water and wastewater

\footnotetext{
${ }^{47}$ Unlike Ontario and Quebec, there were instances of joint administration of the program in "secretariats" that involved both provincial and federal officials working together in co-located facilities (Alberta and Manitoba) or in "virtual secretariats" where the location of government offices in separate cities precluded sharing facilities (B.C. and Saskatchewan).

${ }^{48}$ This requirement affected a significant part of the Liberal caucus, as Liberal MPs in Ontario constituted the largest block of the government's majority in the House of Commons. Many complained that the operating rules for project selection in Ontario gave less visibility to the federal government (and, more importantly) to them as Liberal MPs.
} 
facilities" (Liberal Party of Canada, 2000, 20). ${ }^{49}$

Red Book III also committed the Liberal government to making investments that improved public transit infrastructure and "to ensure that every community in Canada (had) access to high speed Internet services" $(2000,26-27)$. Clearly the 'picks and shovels' focus of CIWP was supposed to evolve into a differently focussed infrastructure program. However, the two programs still shared a lot in common.

\section{Program Design}

The Infrastructure Canada Program used the same approach in allocating federal funds as CIWP, using a formula based on population and unemployment. While the basic policy rationale for CIWP was tied to tallying the number of jobs created through infrastructure investments, employment creation was no longer the primary driving force for ICP. In Budget 2000, however, the Liberal government now hitched its rationale for funding municipal infrastructure to the concept of fairness:

... governments must recognize the unique challenges confronting rural and remote communities. These include the difficulties faced by farm families on the Prairies and across the country, the anxieties of Canada's mining or other singleindustry towns and the loss of traditional sources of employment on both coasts ... such concerns may be compounded by the anxiety that people's prospects are growing worse and that, in spite of better times, the overall benefits of the new economy will pass them by. Governments must not allow this to happen. Indeed, the new economy offers opportunities to rural Canada. In the year ahead, all orders of government must work to broaden and harness these opportunities so that the benefits of the new economy take root in all parts of the country. With this in mind, the federal government will consult with other orders of government and the private sector to reach agreement on a creative and fiscally responsible multiyear plan to improve provincial highways and municipal infrastructure in cities and rural communities across Canada (Canada, 2000, emphasis added).

The underlying message in the Budget of more promised federal spending was meant to

\footnotetext{
${ }^{49}$ While the commitment to create the municipal building code was never fulfilled, $\$ 12.5$ million in funding from the Budget was allocated to develop the National Guide to Sustainable Municipal Infrastructure: Innovations and Best Practices ("InfraGuide"), a compendium of state-of-the-art methodologies for municipal infrastructure. Details on the project are provided in Chapter 4.
} 
counter the damage to the Liberal plurality in the House of Commons during the election in 1997. The Liberals had felt the wrath of voters - especially those in the Atlantic provinces - who lost benefits as a result of spending cuts from Program Review. ${ }^{50}$

The Liberals' approach to investing in municipal infrastructure - whereby federal funds were dispersed across the country regardless of 'need' - became entrenched in the agreements for each province and territory. The concept of 'entitlement' was embedded in the allocation of funds, notably in Alberta where every community received funds according to a preset formula. Rural 'targets' were also established in all agreements: a portion of program funds was allocated based on to the percentage of a jurisdiction's rural population..$^{51}$

Although the Liberal government's decision to include the rate of unemployment in calculating the allocation of federal funding was seen as politically safe and ' $\mathrm{fair},{ }^{, 52}$ it undermined the environmental policy rationale for the program. As Soberman had observed during his evaluation of CIWP, equal treatment is not necessarily synonymous with equitable treatment. Sprinkling federal funds to all communities does not necessarily reflect the real disparity in actual needs, both from the perspective of protecting the environment and responding to the existing conditions of infrastructure in a community.

In January 2001, the newly re-elected Liberal government committed in the Speech from the Throne that, "a healthy environment is an essential part of a sustainable

\footnotetext{
${ }^{50}$ While the Liberals maintained a majority in the House of Commons following the 1997 election, their plurality dropped by twenty-three seats. They were completely shut out of Nova Scotia.

51 'Rural targets' for each province and territory are available in Infrastructure Canada's website, http://www.infrastructure.gc.ca/ip-pi/icp-pic/agreements-ententes/index e.shtml.

${ }^{52}$ The decision to use the same CIWP formula for allocating federal funding was based on a concern than introducing a new formula - such as a jurisdiction's contribution to GDP - would favour central Canada. Blending population and unemployment was seen as the safest way to negotiate agreements with the provinces and the territories.
} 
economy and our quality of life ...(and) the Government's focus will be on the three priorities of clean air, clean water, and the conservation of Canada's natural spaces" (Canada, 2001 a). However, the commitment to focus on the environment had little impact on the design and delivery of the new Infrastructure Program. The ICP agreements with the provinces and territories had been signed months earlier; a significant proportion of ICP funding that was to be used for municipal infrastructure projects had little to do with clean air and clean water.

\section{Program Results}

The Auditor General had criticized ICP's predecessor - CIWP - for its "lack of clarity in a number of key targeting requirements established as part of the Program's design, including what actually constitutes infrastructure or an incremental investment for the purposes of the Program" (Auditor General of Canada, 1999, para. 17-101). The broad definition of infrastructure allowed communities to obtain funding for a wide diversity of assets, from park benches to multi-million dollar trade and convention centres, from swimming pools to waste water treatment plans.

The goal of the ICP was to "help to renew and build infrastructure in rural and urban municipalities across Canada." ${ }^{, 53}$ The declared outcomes for the program included enhancement of the quality of the environment, support for long-term economic growth, improvement of community infrastructure, increased innovation and use of new approaches and best practices, and more efficient use of existing infrastructure. Similar to CIWP, the program was designed to be a 'bottom-up' exercise, whereby local governments would submit project proposals for funding to the province/territory and the

\footnotetext{
${ }^{53}$ Details about the program are available from the Infrastructure Canada website, http://www.infrastructure.gc.ca.
} 
federal government. Proposals were supposed to indicate how projects would support program outcomes.

While the categories of infrastructure and types of eligible projects were less numerous than CIWP, municipalities nevertheless were provided with considerable flexibility. The first priority for funding was directed at "green municipal infrastructure" - projects that "improved the quality of the environment and contributed to national goals of clean air and water." 'Green infrastructure' included projects involving water and wastewater systems, water management, solid waste management and recycling; nearly $54 \%$ of federal funding was spent in this category. Following criticism from the Commissioner of the Environment and Sustainable Development that funding potable water projects does not improve the environment, the definition of 'green infrastructure' was amended (Auditor General of Canada, 2003, Chapter 3). It was now defined as "that which improves the physical environment or the quality of human life through environmental or health benefits, respectively" (Infrastructure Canada website).

However, the definition of 'green' used in ICP was at odds with what is generally understood in the field of sustainable development. The Green Municipal Fund ${ }^{54}-$ an endowment created by the federal government that is administered by the FCM - defines green infrastructure as that which includes "technologies that prevent pollution, use resources efficiently and capitalize on natural systems to provide municipal services" (Federation of Canadian Municipalities, 2005, 17, emphasis added).

'Green' infrastructure involves ecological forms that are more effective at looping

\footnotetext{
${ }^{54}$ The federal government provided the Federation of Canadian Municipalities with $\$ 550$ million to create the Green Municipal Fund (GMF). The Fund offers grants and low-interest loans for "innovative environmental infrastructure initiatives that generate measurable environmental, economic and social benefits." See the Green Municipal Fund website, http://www.fcm.ca/english/gmf/gmf.html
} 
scarce resources, and at cascading energy flows through multiple end uses. There is a greater emphasis on achieving thermodynamic efficiency for the systems as a whole, creating systems that are inherently more adaptable and resilient. The net result is an integrated infrastructure system with a reduced ecological footprint over its life cycle, and with significant benefits for the community's economy and the quality of life of residents (Sheltair Group). Most projects funded under ICP as green infrastructure would not pass muster under this definition, particularly the criteria relating to capitalizing on natural systems. Rather than promoting such measures, the ICP (as well as subsequent federal municipal infrastructure programs) followed in the footsteps of CIWP in encouraging capital accumulation and the expansion of infrastructure systems.

Of the other major categories of infrastructure that were eligible for funding under ICP, $22 \%$ of program funding was directed to local transportation, $18 \%$ went to culture and recreational facilities, and $4.4 \%$ was allocated to tourism. ${ }^{55}$ Funding was also available for projects that involved affordable housing, rural and remote telecommunications, and high-speed access for local public institutions. While the 1999 Speech from the Throne had called for more investments in 'infrastructure for the $21 \mathrm{st}$ Century,' municipalities expressed little interest in funding projects related to rural and remote telecommunications and high-speed access. ${ }^{56}$ As well, during the 2000 federal election, the Liberal platform (Red Book III) had emphasized the need to make investments that improved public transit infrastructure: "Business and municipal leaders, urban planners, and environmentalists agree that there is an urgent need for reinvestment

\footnotetext{
${ }^{55}$ Source: Infrastructure Canada, Shared Information Management System for Infrastructure (SIMSI), April 2006.

${ }^{56}$ Despite the federal interest in funding rural and remote telecommunications and high-speed access for local public institutions, less than $\$ 10$ million (.5\% of program funding) was spent for these areas. Source: SIMSI, April 2006.
} 
in public transit"'(Liberal Party of Canada, 2000, 26, emphasis added). Apart from

Edmonton, Toronto and Montreal, there was little interest in seeking federal funding for projects that involved improvements to public transit. ${ }^{57}$

Similar to the results of CIWP, the share of funding under the Infrastructure Canada Program that was directed to new and expanded infrastructure far exceeded that which was used for renewal. While nearly 54 per cent of ICP federal funding was applied to 'green infrastructure' (including water and wastewater systems and water management), more than 60 per cent involved the construction of new and expanded infrastructure. ${ }^{58}$ More than 77 per cent of the $\$ 355$ million in federal funding was spent on new and expanded cultural and recreational facilities. Nearly 58 per cent of $\$ 85$ million in federal funding was spent on new and expanded tourism infrastructure. As with CIWP, the only significant amount of funding that was targeted to the repair of existing assets involved local transportation (roads and bridges). More than 73 per cent of the $\$ 426$ million in federal funding for transportation projects was committed for this purpose. Like CIWP, it is not surprising that many municipalities again decided to use whatever federal and provincial funding they could get to undertake small road projects of the 'shave and pave' variety.

Overall, the bulk of funding from ICP was not used to repair municipal infrastructure. The results from ICP closely parallel those of CIWP and bring to mind the observations made by Richard Soberman that the municipalities had undermined the basic rationale for federal funding: "Municipalities argued strongly for assistance to deal with decaying infrastructure and then used most of the money for system expansion."

\footnotetext{
${ }^{57}$ Source: SIMSI April 2006. Montreal's metro received over $\$ 100 \mathrm{M}$ for renovations; Toronto's TTC received $\$ 76 \mathrm{M}$ for improvements; and Edmonton's light rail (LRT) received $\$ 8.6 \mathrm{M}$

${ }^{58}$ Source: SIMSI April 2006.
} 
The 'need' for funding for many small projects was also suspect. In its submission to the Minister of Finance for the Millennium Budget, the FCM had argued that there was a need for a new federal infrastructure program since there were "a number of outstanding infrastructure projects which (local governments could not) finance out of municipal revenues alone" (added emphasis).

While CIWP allocated $\$ 2.4$ billion to more than 17,000 projects, ICP allocated slightly less funding ( $\$ 2.05$ billion) for far fewer projects -3554 in total. However, like its predecessor, during ICP there were many instances in which very small amounts of federal funding were transferred to local governments. For example, the federal government provided $\$ 975$ towards the total costs of $\$ 2,926$ to upgrade a pump house in a small rural community in Alberta; another project involved a federal payment of $\$ 3,333$ towards the share of $\$ 10,000$ to replace fire hydrants in another nearby community; a project involving sidewalk upgrades in a rural hamlet received $\$ 2,149$ in federal funding. ${ }^{59}$ Such small amounts undermine the FCM's argument that there was a 'need' to provide federal funding for projects that the local municipality could not finance out of municipal revenues alone.

The request for federal funding for very small infrastructure projects also raises questions about the efficiency of transferring revenues that provincial and territorial governments could accommodate easily on their own. Of the projects that received funding under ICP, nearly 9 per cent received less than $\$ 10,000$ from the federal government (these projects accounted for slightly over .07 per cent of the $\$ 2$ billion in federal funds). Over one-third of the total projects funded under the program received less than $\$ 50,000$ from the federal government; these 1206 projects accounted for slightly

${ }^{59}$ Source: SIMSI April 2006, project \#10470; project \#8855; and project 9791. 
over 1 per cent of the $\$ 2$ billion in federal funds. From a public works perspective, the small amounts of funding involved in these transfers for municipal infrastructure projects are relatively insignificant within the overall capital budget of local governments. As well, many provinces and territories routinely provide capital grants to municipalities for infrastructure, funding which greatly exceeds that provided by ICP. From a public policy perspective, given the cost of overhead involving resources from each of the three levels of government to administer the funding and the minor impact on program outcomes for small projects, there is a very weak rationale for transferring such small amounts of federal funding to local governments.

Despite the absence of logic in applying the same program rules (approval process, administration, audit and reporting) to all projects regardless of the level of funding provided, there was no minimum threshold for project funding under ICP. The federal Cabinet did not want to establish a threshold since all projects gave the Liberal ministers and backbench MPs local visibility, even in those ridings served by opposition MPs. As Vining and Weimer observed,

(i)f legislators can obtain the public credit for particular projects, many potential infrastructure investments are ideal candidates for attracting constituency votes because they are location specific and tangible, involve considerable accumulation of physical assets ('sunkness,' which usually offers some credible commitment to future spending), and are labor intensive (at least from the constituency's accounting perspective) (147-48).

While the approval process for federal funding under ICP was somewhat more streamlined, all projects - regardless of dollar value - were still signed off by ministers who wanted to keep their hands on the administration of the program. ${ }^{60}$

\footnotetext{
${ }^{60}$ The federal Cabinet could not accept the idea of having funding approved by bureaucrats, unlike several provincial governments that had authorized delegated project approvals and spending limits to their
} 
Despite the similarity between CIWP and ICP, there was a noticeable difference: the communications regime spelled out in the ICP agreements with the provinces and the territories was much more rigorous than that which had existed during CIWP. Each agreement included a "communications protocol" that committed those who received federal funding to ensure that federal government would be given sufficient prominence in communications related to the project. ${ }^{61}$ Federal visibility had to be guaranteed when the funding for projects was announced, along with assurances that federal ministers and local MPs (at least those on the government benches) would be given ample notice to attend any ceremonies that announced funding at the beginning of the project as well as ribbon-cutting ceremonies at project completion. Signage during construction had to pass muster according to several criteria, including the prominence and placement of the Canada wordmark. The communications activities related to the projects funded under ICP provided valuable political currency, especially for Liberal MPs. Media events for ICP projects gave them visibility and allowed them to claim responsibility for being able to deliver federal funds for the communities in their riding.

\section{The Canada Strategic Infrastructure Fund (2002- )}

In Budget 2000, the Chrétien Liberals sought new ways of spending the large surplus in the federal treasury by transferring significant amounts of federal cash to

officials. The federal Liberals wanted to keep close connections between those in Cabinet who could sign off on funding and MPs who lobbied on behalf of their constituents.

${ }^{61}$ See Annex 'C' (Communications Protocol) of the ICP agreements, available at http://www.infrastructure.gc.ca/ip-pi/icp-pic/agreements-ententes/index e.shtml 
NGOs and newly created foundations, greatly vexing the Auditor General. ${ }^{62}$ The federal government recorded a budgetary surplus of $\$ 17.1$ billion in 2000-01; the market debt-toGDP ratio had declined to 42.3 per cent, down from its peak of 57.8 per cent in 1995-96 (Canada, 2001 b). In Budget 2001, Paul Martin delivered his last budget as Minister of Finance in the Chrétien government. In response to the crisis at the border following $9 / 11$, he announced that the federal government would allocate $\$ 600$-million for a new Border Infrastructure Fund that would invest in improvements to highways, commercial vehicle processing centres and technology to support major border crossings.

As well, the Minister of Finance announced that the federal government would create the Strategic Infrastructure Foundation, a new arms-length organization. With "a minimum federal commitment of $\$ 2$ billion," the new Foundation would fund "large strategic projects." "Strategic investments" would provide the "bridging to the future" (Canada, $2001 \mathrm{~b}$ ). The Finance Minister stated that, "targeted investments ...will both stimulate job creation and confidence in the short term and make the economy more productive and competitive in the long term."

Much to the chagrin of Paul Martin, the Prime Minister thwarted his plans to create an independent Foundation. ${ }^{63}$ While Budget 2001 documents from the Department of Finance still refer to the government's intention to create the 'Strategic Infrastructure Foundation, ${ }^{, 64}$ the Foundation was never created. When he was advised very late in the

\footnotetext{
${ }^{62}$ The Auditor General sharply criticised the federal government's practice of creating and funding entities outside the reach of her oversight. She has raised the issue in several reports, notably 2002, Chapter 1 "Placing the Public's Money Beyond Parliament's Reach" and 2005, Chapter 4 "Accountability of Foundations," http://www.oag-bvg.gc.cal

${ }^{63}$ The clash between the PM and the Finance Minister culminated five months later, when Martin discovered while he was listening to his car radio that he was no longer in Cabinet. As Rex Murphy quipped, "Paul Martin ceased to be Finance Minister sometime during an immensely popular CBC radio program. Its name eludes me." http://www.cbc.ca/national/rex/rex20030101.html

${ }^{64}$ See Finance Canada's website at http://www.fin.gc.ca/budget01/pdf/briefe.pdf
} 
Budget process, the Prime Minister overruled the Finance Minister; not surprisingly, there were those in the Department of Finance who were required to fall on their swords. The PM preferred to create a government program that he and his ministers - not an anonymous board of directors of an arms-length foundation - could control. ${ }^{65}$

The PM's desire to establish a closeness between the levers of political power and the administration of billions of dollars in discretionary funds illustrates the point made by Savoie that, “...majority-party politicians ... have the power to engage in constituency vote-maximizing behaviour, most notably the prime minister, senior cabinet members (especially those with regional responsibilities), and the ministers of agencies that are directly involved with various kinds of infrastructure spending" (cited by Vining and Weimer, 148). The new government program was given the somewhat curious name of the 'Canada Strategic Infrastructure Fund' (CSIF) as an attempt to camouflage the transition from the Budget's reference ('foundation') to subsequent legislation and ensuing government communiqués ('fund').

As part of the major changes to the Ministry announced in January 2002, the Prime Minister also changed the machinery of government. ${ }^{66}$ Prior to 2002, the President of the Treasury Board was responsible for administering federal funding for municipal infrastructure. ${ }^{67}$ The billions of dollars in new funding for infrastructure - including CSIF as well as the new Border Infrastructure Fund (BIF) and the existing Infrastructure

\footnotetext{
${ }^{65}$ The Green Municipal Fund administered by the FCM was an example of the 'arms-length' foundation created by the Minister of Finance in Budget 2000 (see supra 66).

${ }^{66}$ PCO Press Release, January 15, 2002. The changes to the Ministry were triggered by the sudden resignation of Brian Tobin from his position as Minister of Industry. Other notable changes to Cabinet included the departure of Herb Gray from the position of Deputy Prime Minister. John Manley replaced Gray; Allan Rock replaced Tobin.

${ }^{67}$ The position was styled as 'President of the Treasury Board and Minister responsible for Infrastructure.' The Infrastructure National Office served the Minister as part of the Treasury Board of Canada Secretariat from 1994-2002.
} 
Canada Program - would now be channelled through the Prime Minister's department and the Cabinet Secretariat - the Privy Council Office. ${ }^{68}$ Political oversight would be provided by the newly appointed Deputy Prime Minister and Minister of Infrastructure and Crown Corporations and Minister with political responsibility for Ontario - John Manley.

The structure and staffing of the new department reflected the close relationship with political masters, much like that described by Wilson, who observed that, “...it is this meshing of political expediency and bureaucratic pragmatism that creates the nexus between the Liberal party and the public service...." (459). The policy and communications functions were combined in one sector, in sharp contrast to the usual practice in the federal bureaucracy. ${ }^{69}$ As well, the deployment of staff from the offices of two cabinet ministers to senior administrative positions in the department underscored the importance of establishing and maintaining political links. The relationship between the bureaucracy and political staff in the administration of CSIF and BIF closely resembled that which occurred in the infamous Sponsorship Program, particularly during the last year of the Chrétien government. As Gomery observed,

The concentration of power in the office of the Prime Minister is a phenomenon of modern Canadian government which has been noted with concern by academics and commentators. The dangers created by that concentration are demonstrated by the 'sponsorship scandal.' As shown by the evidence, if a proposal or program is perceived as being supported by the PMO, politicians and public servants alike, mindful of the effects that opposition might have on their careers, hesitate to object to it in any fashion, no matter how ill-conceived or

\footnotetext{
${ }^{68}$ In a Press Release issued by PCO on March 11, 2002, the Prime Minister announced that the "Deputy Secretary to the Cabinet (Operations), Privy Council Office, has been appointed to serve concurrently as Deputy Head of the Office of Infrastructure and Crown Corporations of Canada."

${ }^{69}$ In the federal government it is rare to combine policy and communications functions. Most departments separate them, preferring to include communications as a 'corporate service' function. As one senior communications official from TBS explained, "combining policy and communications is an old model from the 1980's and 1990's, based on the belief that those who control policy wanted to be able to control the spin."
} 
poorly administered it may be. This undermines the whole concept of a professional and non-partisan pubic service, fearlessly giving objective advice to its political masters (434)

Unlike previous infrastructure programs that involved a 'bottom-up' process in which municipalities would submit requests for infrastructure funding, there was no application process for either CSIF or BIF. Ministers and their political staffers would now directly control the selection of "strategic projects" and determine the amount of funding that would be allocated. As Gomery had observed, while "exempt or political staffers do not have authority to give direction to public servants ... they can, and often do, exert a substantial degree of influence on the development and in some cases on the administration of public policy in Canada"(135). Rather than basing decisions on public policy interests, the selection process became very much enmeshed in politics.

\section{Program Design}

The Finance Minister's announcement in Budget 2001 that the federal government was establishing the "Strategic Infrastructure Foundation" was reversed through legislation. Within a few weeks after the Budget Speech, the Canada Strategic Infrastructure Fund Act (Bill C-49, Part 6) was hastily drafted as part of the Budget Implementation Bill, establishing "a program to provide for the payment of contributions to eligible recipients for the carrying out of large-scale strategic infrastructure projects that contribute to economic growth or quality of life in Canada and that advance Canada's objectives with respect to infrastructure." The legislation gave the Minister responsible for infrastructure (initially the Deputy Prime Minister) authority “to enter into an agreement with an eligible recipient to provide for the payment of a contribution for an eligible project." The Act provided considerable latitude in this regard (see Table 4). 


\section{Table 4 - CSIF Act Definitions}

\begin{tabular}{|c|c|}
\hline $\begin{array}{l}\text { Strategic } \\
\text { Infrastructure }\end{array}$ & $\begin{array}{l}\text { Any of the following fixed capital assets that are used or operated for the } \\
\text { benefit of the public: } \\
\text { (a) highway or rail infrastructure } \\
\text { (b) local transportation infrastructure; } \\
\text { (c) tourism or urban development infrastructure; } \\
\text { (d) sewage treatment infrastructure; } \\
\text { (e) water infrastructure; or } \\
\text { (f) infrastructure prescribed by regulation.* }\end{array}$ \\
\hline Eligible projects & $\begin{array}{l}\text { A large-scale project for the construction, renewal or material enhancement of } \\
\text { strategic infrastructure that is carried out, or to be carried out, by an eligible } \\
\text { recipient. }\end{array}$ \\
\hline Eligible recipients & $\begin{array}{l}\text { The following are eligible recipients: } \\
\text { (a) a province or a municipal or regional government established by or under } \\
\text { provincial legislation; } \\
\text { (b) a public sector body that is established by or under provincial legislation or } \\
\text { by regulation or is wholly owned by a province or a private sector body that is } \\
\text { in partnership with a province or a government referred to in paragraph (a), if } \\
\text { the body } \\
\text { (i) carries out or, in the opinion of the Minister, is capable of } \\
\text { carrying out an eligible project in Canada, and } \\
\text { (ii) has legal capacity, or is composed of organizations each of which } \\
\text { has legal capacity; and c } \\
\text { (c) a private sector body that } \\
\text { (i) carries out or, in the opinion of the Minister, is capable of } \\
\text { (ii) has legal capacity, or is composed of organizations each of which } \\
\text { has legal capacity }\end{array}$ \\
\hline \multicolumn{2}{|c|}{$\begin{array}{l}\text { * Note: Regulations were subsequently passed that added 'broadband access' to the types of infrastructure } \\
\text { that were eligible for funding under the Act. }\end{array}$} \\
\hline
\end{tabular}

While federal funding would be made available to support "large scale project(s) (involving) the construction, renewal or material enhancement of strategic infrastructure," neither "strategic" nor "large scale" were defined within the Act. The absence of clarity in the legislation created consternation among parliamentarians, who had considerable difficulty in understanding what was meant by 'strategic' infrastructure and what criteria was applied by the government when making decisions to spend tens (and occasionally hundreds) of millions of dollars for a single infrastructure project. The 
answers that were provided were hardly elucidating. ${ }^{70}$ The Chrétien Liberals preferred the vagueness afforded by the language in the CSIF Act since it permitted considerable flexibility in the administration of the program, greatly facilitating their ability to make decisions based on political rather than public interest. Such flexibility would not have been possible with an anonymous board of directors of an arms-length foundation.

Unlike earlier infrastructure programs, CSIF permitted the contribution of the Government of Canada to exceed a one-third share, to a maximum of 50 per cent of total eligible costs of a large-scale project. Defining what was meant by "large-scale" was therefore an extremely important selection criterion for the program, both in terms of determining a project's eligibility for funding as well as setting the maximum amount of federal funding that was available. However, there was no strategic plan or clear policy for either CSIF or BIF that provided a rationale for federal spending in these programs. For several months after the CSIF Act was enacted, little information was available to explain what "large scale" infrastructure involved and how the new program would operate.

\footnotetext{
${ }^{70}$ The exchange at the House of Commons Standing Committee on Environment and Sustainable Development (Number 012, $3^{\text {rd }}$ session, $37^{\text {th }}$ Parliament) that took place on Wednesday April 21, 2004 illustrates this point quite well:

Committee Chair: "When I read the Vancouver Convention and Exhibition Centre, I wonder how that made its way and soaked up \$222 million, or a twinning of Route 175 soaking up $\$ 262$ million ... How is it that these projects of twinning of routes and the Vancouver Convention Centre come in as strategic? What makes them so strategic?"

Minister of State: (Andy Scott): "Probably the best way to explain it would be to say that if I were the infrastructure minister a year ago, I'd be appearing before the industry committee. As a result, the industry committee's view of strategic would be different from the environment committee's view of strategic. And I'm here to say that a change has taken place, moving forward."

(...more evidence is presented)

Committee Chair: "'Strategic' has many dimensions, as we all know. It has a military dimension, and an economic, social, and environmental one. We're trying desperately to understand what dimension you accept in determining what is strategic ..."
} 
Following more key departures in the Chrétien Ministry, ${ }^{71}$ the Office of Infrastructure of Canada was created in August 2002 as a separate agency that was part of the Industry Canada portfolio, reporting to the Minister of Industry and Minister responsible for Infrastructure (PCO, 2002). The broad operating rules for CSIF or BIF were announced through a hastily produced Press Release issued on August 22, 2002. 'Large-scale' projects under CSIF were defined in relation to the population of a jurisdiction and to the total costs of construction. In other words, a $\$ 25$ million project was considered large-scale and strategic in one province but could not be considered large-scale and strategic in an adjoining province. ${ }^{72}$ The logic of this policy was based on an interpretation that 'large-scale' and 'strategic' were relative to "the context or territory in which they are housed" (Infrastructure Canada website) rather than to their importance to the nation as a whole.

In theory, any municipality in the country could rightly claim that, if their proposed infrastructure project was of a type that was included in the list of eligible assets and the project costs met the threshold of costs for their jurisdiction, it too could be deemed "strategic" and worthy of federal funding. However, no municipal government

\footnotetext{
${ }^{71}$ Paul Martin was replaced as Minister of Finance following his 'New Deal for Cities' speech at the FCM Annual Conference in May 2002. John Manley became Deputy Prime Minister and Minister of Finance. In August, 2002, his responsibilities for infrastructure were transferred to Alan Rock, Minister of Industry.

${ }^{72}$ Eligibility for funding was scaled according to the population of the jurisdiction: under 750,000 ( $\$ 10$ million); between 750,000 and 1.5 million ( $\$ 25$ million); and over 1.5 million ( $\$ 75$ million). While most projects that have received funding had to meet this 'threshold' of costs for their jurisdiction, the rules were overlooked when it was politically convenient. Thus, two small and very dissimilar projects in the riding of one minister were combined to make them eligible; as well, seven projects in seven different communities in Nunavut were combined. While these latter projects - which included the construction of sewage lagoons - is of considerable value to the communities, their description by the federal government as "strategic large-scale projects of major national and regional significance" is suspect (see News Release, May 30, 2006. http://www.infrastructure.gc.ca/ip-pi/csif-fcis/newsnouvelles/2006/20060530iqaluit_e.shtml
} 
dared to challenge the realpolitik of federal largesse given the risks and inevitable consequences.

Unlike earlier infrastructure programs that invited all municipalities across the country to apply for federal funding, the operating rules for CSIF and BIF were based on a distinctly political process. There were no applications or 'business cases' to complete and submit in order to be considered for federal funding. During his review of the Sponsorship Program, Gomery observed on what constituted the 'usual practice' in the public service:

Prior to the implementation of any new government program, the usual practice is to develop and make known to interested parties the guidelines which will apply to it. These guidelines would normally explain: the objectives of the program; a description of the means adopted to achieve these objectives; where the program involves the disbursement of public funds on a discretionary basis, the criteria which will guide the decision-maker; and the procedures to be followed by applicants for admissibility to the benefits of the program (165, emphasis added).

Although the August 2002 Press Release about CSIF included the curious statement that, "Government officials have been mandated to formalize discussions with potential partners with a view to identifying large-scale infrastructure projects quickly," in reality the process was very much politicized. Local governments seeking access to program funds were advised to deal directly with the Minister's office and to lobby regional ministers. ${ }^{73}$ Delegations from some provinces arrived to lobby PMO directly, walking the corridors of power in Ottawa to secure agreements involving hundreds of millions of dollars. ${ }^{74}$ Soon after concluding these deals, the Prime Minister and several

\footnotetext{
${ }^{73}$ The lack of transparency in the selection of projects funded under CSIF and BIF was of considerable consternation to those communities who learned too late that the 'envelope of funding' for their province had already been committed for another project.

${ }^{74}$ The government of B.C., for example, made several pilgrimages to talk face to face with the power brokers in PMO, PCO and ministers' offices. Their missions were successful, as they were able to gain access to over three quarters of a billion dollars in federal spending for their infrastructure projects.
} 
of his Ministers would then make public announcements during visits to the provinces, committing the federal government to hundreds of millions of dollars in funding for projects even though there was little evidence of 'due diligence' beforehand. ${ }^{75}$

Despite the Finance Minister's reference in the Budget to the need to make "strategic" investments that would make "the economy more productive and competitive in the long term," the importance of a 'large-scale'. project funded under CSIF was determined according to its relative (and political) value within a jurisdiction rather than its value to the nation. As Richards and Vining observed:

(i)f governments do the right thing in terms of investments in infrastructure, their intervention in the provision and regulation contribute substantially to an economy's aggregate productivity... Frequently, however, governments do not do the right thing. Major infrastructure projects almost always entail discretionary decisions, and vote-maximizing politicians have strong incentives to oblige politically important interest groups, whether or not these lobbies can make a reasonable claim that their pet projects will generate a positive net present value for the economy (12).

In order to meet the demand for more opportunities for project announcements towards the end of Chrétien's mandate, the government increased federal funding for CSIF to $\$ 4$ billion in Budget 2003 and allocated another $\$ 1$ billion for new infrastructure program - the Municipal Rural Infrastructure Fund (MRIF). In July 2003, the Liberals announced how the additional $\$ 2$ billion in funding for CSIF would be spent:

The Government of Canada continues to provide leadership on national priority projects and to pursue partnerships with all levels of government to respond to Canada's infrastructure needs. These investments represent a key component of

\footnotetext{
${ }^{75}$ Due diligence is defined by the Treasury Board as "reasonable care or attention to a matter, which is good enough to ensure that provided funding would contribute to the intended objectives of the transfer payment and stand the test of public scrutiny. This includes: (a) being guided by an understanding of the purpose and objective to be achieved; (b) supported by competence and capability of information, resources and skills; (c) a shared commitment to what needs to be done and an understanding of respective authorities, responsibilities and accountabilities; and (d) ongoing monitoring and learning to ensure reassessment and effectiveness." Source: Treasury Board of Canada Secretariat Policy on Transfer Payments (July 1, 2001).
} 
the Government of Canada's sustained support for Canadian communities (Infrastructure Canada, 2003).

The parameters for CSIF were "adjusted to better address the infrastructure needs of the country, as well as Government of Canada priorities." Areas of investment were broadened to include water quality and access, trade corridors, broadband connectivity, sustainable urban growth, and northern infrastructure. The additional funding was intended to be "strategically targeted to help promote sustainable growth and competitive communities ... (and to) reflect Government of Canada objectives on climate change, urban development, clean water, trade and innovation" (2003, Backgrounder).

While often referring to "sustainable growth," "sustainable urban growth" and "sustainable urban development," the department responsible for administering CSIF Infrastructure Canada - did not define in its public documents what these terms entail. However, a review of the 'performance areas' contained in the department's nonpublished 'accountability framework' for CSIF reveals that "sustainable urban growth" involves "sustainable urban transportation efficiency, increased tourism, business investment and economic development, and Canada leader (sic) in innovative urban transportation systems" $(2004,24)$. The federal government's interpretation of what is meant by 'sustainability' in its multi-billion dollar infrastructure program is an apt illustration of Paehlke's observations:

One might ask ... what it is that we wish to sustain. Reflection on this matter leads quickly to a conclusion that there is not yet a fully shared understanding of the meaning of sustainability. Conservation advocates often are most concerned with the sustainability of nature. For others, the meaning of sustainability is bound up with preserving human health and well being, or - most broadly - 'quality of life.' For still others, sustainability is primarily about sustaining resources to fuel industrial society as we know it (35).

Given the design of the federal government's largest infrastructure program, it is clear 
that its investments supported the latter view.

Following the election of the Harper Conservative government in 2006, the federal government declared that there was a need to add more funds to CSIF. The $\$ 4$ billion fund was nearly depleted by the Chrétien and Martin governments. In its first Budget, the Harper government declared that, "an additional $\$ 2$ billion for the Canada Strategic Infrastructure Fund ... will allow the Government to fund new projects." Like the Liberals, the Conservatives came to appreciate the political value in spending large amounts of federal dollars on municipal infrastructure.

\section{Program Results}

Projects funded under CSIF were expected to provide a wide variety of benefits. Infrastructure Canada presented its commitments to the Treasury Board in a ResultsBased Management Accountability Framework (RMAF) ${ }^{76}$ for the program. The "planned results" for CSIF included the following expected achievements:

... facilitate the movement of goods and people on Canada's NHS (National Highway System) and mainline rail network for the purposes of increasing the productivity, economic efficiency, and safety of Canada's surface transportation system; facilitate the sage and efficient movement of goods and people, ease congestion, reduce greenhouse gases and airborne pollutants; promote Canada as a leading destination for tourists as well as promote sustainable and planned urban development; provide for safe, clean, and reliable drinking water as well as provide for the environmentally responsible and sustainable treatment of wastewater; and provide for improved sustainable rural development and remote access to key services" (Infrastructure Canada, 2004, 9).

In addition to these outcomes for the program, the federal government expected that its investments in projects would result in reinforcing the "perceived legitimacy of (the) Federal role in infrastructure" $(2004,21)$. The criteria for this "performance area" for the

\footnotetext{
${ }^{76}$ The RMAF is a management tool prescribed and approved by Treasury Board. It is a "blueprint for managers to plan, measure, evaluate and report on results throughout the life cycle of a policy, program or initiative." Treasury Board Secretariat "Guidance for Strategic Approach to RMAFs"
} 
program included the following elements: "\% of Canadians who perceive Federal role (sic) in Infrastructure as legitimate, appropriate and well managed/effective;" and “observed complaints/objections by various stakeholders" $(2004,21)$.

Each 'performance area' for the program included indicators that are applicable according to the category of projects funded. However, the manner in which "performance areas" were measured was incongruous. Many indicators expressed as 'ultimate outcomes' for the program are linked to the effectiveness of the management of the infrastructure itself, despite the fact that the operation of the asset created was the responsibility of municipal government and/or provincial government, not the federal government.

In view of the promised outcomes that were expected from projects receiving federal funding as well as the significant amount of dollars involved, it could be assumed that the project selection process would be rigorous. Unfortunately, such an assumption would be wrong. The selection process for CSIF was very much driven by political expediency - political interest trumped public policy. As Hulten and Schwab observe,

“(c)ost-benefit analysis, for all its inherent flaws, remains the most reliable guide to the value of future infrastructure projects. A sound infrastructure policy must rely far more heavily on cost-benefit analysis and less on political criteria in the design and selection of infrastructure projects (199).

When the Prime Minister and ministers publicly announced commitments of billions of dollars in federal funding for projects funded under CSIF, little information was available to justify the decision from a policy perspective.

Of the $\$ 4$ billion allocated to the CSIF by Liberal governments, more than $\$ 3.5$ billion has been committed. ${ }^{77}$ The greatest proportion of funding ( $\$ 1.4$ billion) was

\footnotetext{
${ }^{77}$ Figures from Infrastructure Canada as of April 2006.
} 
directed to five transit projects. ${ }^{78}$ While Infrastructure Canada's website makes the claim that "public transit projects ... contribute to sustainable development goals" the department has not defined what these goals are and how they would affect decisions concerning infrastructure development and land use. Providing more than $\$ 700$ million for transit projects in the Toronto area may be good politics, but it is not necessarily good public policy.

As demographics and transport consultant Wendell Cox has observed, "To be automobile competitive, the transit system would have to provide access to virtually all locations, or certainly all major employment centers, from all over the region.... not even those who think that transit is the answer can torture the computer models enough to produce results that make a difference" (7-8). Mintz and Roberts also question the policy rationale for transit subsidies, citing Brueckner's argument that:

... subsidies for public transit may contribute to urban sprawl, similar to other transportation subsidies. This occurs because it lowers the private cost of living far away from a city center, even when the social cost of that travel is higher. Although there might be some argument for a higher subsidy for train transit than for roads, large subsidies for urban transportation are not efficient $(2006,21)$.

The construction of public transit mega-projects in Vancouver with $\$ 450$ million in federal funding and Ottawa (\$200 million) offered political capital that was exceptionally enticing both to federal and provincial politicians. As Lorinc points out, the ambrosia of spending public funding for mega-projects is hard to resist:

For many politicians, transit projects represent a lasting personal legacy that shine far brighter than much of the abstract work of governing. They also attract the attention of construction contractors, engineering consultants, and the large firms that make transit vehicles. Consequently, it's not hard to fund examples of transit schemes where vested interests prevailed over sound planning ... The point is that

\footnotetext{
${ }^{78}$ These include: the Canada Line in B.C. ( $\$ 450$ million); GO transit in Ontario ( $\$ 385$ million, which includes $\$ 65$ million from the Toronto Waterfront Project); the $O$ train in Ottawa ( $\$ 200$ million); the TTC in Toronto ( $\$ 350$ million); and the York Quick Start Transit ( $\$ 50$ million).
} 
building pricey new rapid transit lines can soak up huge sums of public funds without necessarily improving service (243-244).

In each of these projects, the availability of significant federal funding acted as a catalyst that drove decision-makers into a frenzy. ${ }^{79}$ Expediency in getting the projects announced and started - rather than sound public policy that included the consideration of alternatives - ruled the day.

The environmental impact of transit construction is also downplayed in the eagerness to begin construction. The new $\$ 2.0$ billion transit project in Vancouver, for example, is expected to produce massive amounts of green house gases (GHGs) as a result of the extensive use of concrete in building the 'cut and cover' trenches and tunnelling that will form the subway for most of the $19 \mathrm{~km}$ of the new line. ${ }^{80}$ The federal government's $\$ 450$ million investment in this project is at odds with one of the principle outcomes that the department has defined for CSIF, namely investments in infrastructure involving "innovative technologies and practices to minimize green house gas emissions."

The next highest level of funding ( $\$ 1$ billion) was directed to seventeen highway projects ranging in amounts from $\$ 10$ million in federal funding to $\$ 262.5$ million. The ad hoc selection of these highway projects was facilitated greatly by the absence of an updated National Transportation Plan. As Lorinc observed, the federal government also

\footnotetext{
${ }^{79}$ In the case of a mega transit project in $\mathrm{BC}$ - initially given the name RAV, 'Richmond-AirportVancouver' - the Transit authority (Translink) voted twice against the development of the expensive northsouth line, until the province provided legislative muscle to get a third vote that supported the project. The Ottawa LRT project is another example of the folly involved in decision making about public transit projects.

${ }^{80}$ There is a significant environmental impact involved in the production of cement, which is the principal ingredient in concrete. Producing one tonne of cement results in the emission of approximately one tonne of $\mathrm{CO}_{2}$, created by fuel combustion and the calcination of raw materials. Cement manufacturing is a source of greenhouse gas emissions, accounting for approximately $7 \%$ to $8 \%$ of $\mathrm{CO}_{2}$ globally, and approximately $1.8 \%$ of $\mathrm{CO}_{2}$ emissions in Canada . Source: Ecosmart concrete, http://www.ecosmartconcrete.com/enviro_cement.cfm
} 
ignored advice that recommended against more funding for highways:

Ottawa ... has increasingly insinuated itself into the highway building game in recent years, despite ample evidence from south of the border that federally funded urban highway programs are destructive ... New suburban highways attract and concentrate traffic, which is why they clog up so quickly once they are built. The irony is that when former Vancouver mayor Mike Harcourt co-chaired the federally appointed National Round Table on the Environment and the Economy, the group recommended that Ottawa cease all federal funding of highways, except for the Trans-Canada (105). ${ }^{81}$

Twelve wastewater treatment projects received nearly $\$ 300$ million in funding, ranging from $\$ 60$ million towards the construction of treatment plants for Halifax to $\$ 2.3$ million for a sludge management strategy for PEI. The infusion of federal money for some of the larger projects was hardly 'incremental.' The Halifax project, for example, had been under development for years and would have proceeded regardless of federal cash. The construction of a wastewater treatment plant at Thunder Bay - which received $\$ 25$ million in funding from the federal government but no support from the provincial government) - was already well under way before the announcement of federal funding for the project.

As well, the level of treatment that would result from federally funded projects varied considerably: new primary/advanced primary treatment plants (Halifax and St. John's); and upgrades of existing plants to secondary treatment (Charlottetown, Summerside, Thunder Bay and Kingston). There was no policy that required those who received funding for their project to commit to achieving a higher standard of treatment within a specified period of time as a condition for obtaining federal funding. In order to meet the requirements of the Fisheries Act (Fish Habitat Protection And Pollution

\footnotetext{
${ }^{81}$ The 2003 report of the National Roundtable on the Economy and the Environment (NRTEE) "Environmental Quality in Canadian Cities: The Federal role" - is available at http://www.nrteetrnee.ca/Publications/HTML/SOD_Urban E.htm
} 
Prevention, section 34), municipal wastewater needs to be treated to - at a minimum secondary treatment standards. As Lorinc points out, while water and wastewater treatment projects sell well politically, the federal government's approach to these investments was short-sighted: "they deal with only part of our growing water problems ... business-as-usual suburban development continues to inflict extreme pressure on hydrologic features" (113-114).

Another significant level of funding under CSIF (nearly $\$ 300$ million) was directed to tourism projects, including the Vancouver Convention Centre $(\$ 222.5$ million), Mont Tremblant (\$47.5 million) and the City of Niagara Falls (\$25 million) even though the Chrétien government had previously identified a completely different approach to funding tourism projects in an earlier Budget. Budget 1997 had created a financing vehicle for tourism that was administered by the Business Development Bank of Canada and financed through new equity. The new financing arm operated on a commercial basis offering "loans for expansions or upgrades of tourism facilities outside major urban centres"(Canada, 1997, 43). The Finance Minister at the time - Paul Martin - defined the government's expectations with respect to tourism infrastructure:

In addition, we are investing a further $\$ 50$ million in the Business Development Bank to help finance private sector tourism infrastructure. We believe that working with the tourism industry and other financial institutions, it will be possible to lever up to $\$ 500$ million in high quality projects that will attract visitors from abroad $(1997,43)$.

Since the Liberal government had recognized the role of the Business Development Bank in supporting tourism 'on a commercial basis' there was no solid public policy rationale for providing nearly $\$ 300$ million in non-repayable federal cash under CSIF for tourismrelated infrastructure projects in well-developed tourist areas. While comments made a 
decade ago by Andrew and Morrison relate to tourism-related infrastructure projects funded under CIWP, they could apply equally to the projects funded under CSIF:

Generations of municipal politicians have called for projects - such as convention or trade centres - that they claim will lead to economic growth and prosperity. It is faith or boosterism, rather than logic that underlines these claims to links between economic development and infrastructure. What seems apparent is that the infrastructure program has been captured by traditional municipal elites and that the effect of the program is to give them money to pursue their dreams (1995, 130).

It is also worth noting that, despite the lack of social and affordable housing in Canada's major urban centres, only $\$ 20$ million from CSIF was used for this purpose - in

Nunavut. Instead of providing additional housing, Toronto benefited from federal funding for other priorities including the Canadian Opera Company ( $\$ 25$ million), the Toronto Film Festival ( $\$ 25$ million), and the Toronto Soccer Stadium (\$27 million). The program also provided over $\$ 43$ million in funding for projects involving 'more-effective urban development:' three in Saskatchewan ( $\$ 27.7$ million), one in Charlottetown ( $\$ 4.5$ million) and one in the Yukon ( $\$ 11$ million).

Of the investments made under CSIF, those that could most aptly be described as 'strategic' involved broadband. Only $\$ 43$ million of the $\$ 4$ billion in funding from CSIF was provided for this purpose, bringing broadband access to Nunavut, the Northwest Territories, rural and remote schools and communities in Newfoundland and Labrador, New Brunswick and the Magdalen Islands. The strategic essence of these broadband projects was evident in their capacity to transform remote communities, providing access to distance learning and tele-health as well as creating the potential for business opportunities - all this from only 1 per cent of the total funding from the program.

While projects that were funded under CSIF were required to be "large-scale" and "strategic" and "contribute to economic growth or quality of life in Canada and ... 
advance Canada's objectives with respect to infrastructure" neither the CSIF Act nor departmental documents list Canada's objectives in this regard. The accountability framework for the program states that, “(CSIF) investments will be directed to projects of major national and regional significance, and will be made in areas that are vital to sustaining economic growth and supporting an enhanced quality of life for Canadians" (Infrastructure Canada, 2004, 3, added emphasis). There are no criteria that distinguished what was meant by "major" national and regional significance and how an investment in infrastructure would be "vital" to sustaining economic growth. The lack of clarity extended to determining how a project would support an "enhanced quality of life." Rather than ensuring precision in its program design, CSIF employed obfuscated language that provided maximum flexibility in rationalizing project selection decisions that were rooted in political rather than public interest. The Auditor General had roundly reproached the government for the use of vague language in the design of CIWP.

The failure of the federal government to update the country's National Transportation Plan - which the Auditor General had severely criticized following an audit of federal highway programs ${ }^{82}$ - underscored the lack of a strategic framework for the investment of over $\$ 1$ billion in highways under CSIF. As well, despite the Liberal government's commitment in its 1994 Throne Speech that, "It will be the policy of the Government to promote sustainable development as an integral component of decision making at all levels of our society," there was no reference in the CSIF Act requiring

\footnotetext{
${ }^{82}$ The Auditor General criticized Transport Canada for spending over $\$ 1$ billion on provincial/ territorial highways through a series of ad hoc highway investment programs and chastised the federal government for failing to update its National Highway Transportation Policy, which had not been amended in nearly 25 years. The existing policy, which dated back to 1974, was intended to provide overall guidance in establishing and managing highway programs, including determining the priorities for federal investment. Auditor General of Canada (1998), Para 25.128.
} 
projects funded under CSIF to contribute to the goals of sustainable development.

Rather than clearly defining the parameters of what made infrastructure projects "strategic"- linking their relevance to the achievement of established targets in support of federal policies - the federal government's focus under CSIF was to spend on projects that offered dividends in the form of political capital. The selection and announcement of project funding under CSIF closely resembled that of other "ad hoc" grants and contribution programs criticized in previous reports of the Auditor General: “...the absence of a clear policy (created) ... the risk of fragmented, disconnected and inconsistent decision making" (1998, para. 25.20).

\section{The Municipal Rural Infrastructure Fund (2003- )}

While providing $\$ 2$ billion in more funding for CSIF, Budget 2003 also introduced another infrastructure program that was launched shortly before the end of the Chrétien government. The Municipal Rural Infrastructure Fund (MRIF) was allocated \$1 billion as part of a "\$3-billion federal investment over 10 years in strategic and municipal infrastructure. ${ }^{83}$ While 20 per cent of the $\$ 2$ billion in funding for CSIF from Budget 2003 was already targeted for projects that benefited communities of less than 250,000 people, the Chrétien government recognized the political benefits of providing more funding for smaller communities coast to coast. The Harper Conservatives were cognizant of these benefits as well, providing new funding in Budget 2006 that included an additional $\$ 2.2$ billion over five years for the Municipal Rural Infrastructure Fund.

\footnotetext{
${ }^{83}$ The funding available under MRIF was accelerated from ten years to five years under Budget 2004.
} 


\section{Program Design}

Since the program focuses on rural communities, at least 80 percent of funding is dedicated to municipalities with a population of less than 250,000 while the remaining funds were allocated to municipalities with a population over 250,000 . The allocation formula used in the earlier municipal infrastructure programs for calculating the disbursement of federal funding to each jurisdiction was also changed. Rather than using the rate of unemployment, each province and territory and the component for First Nations communities received a base allocation of $\$ 15$ million, with the remaining funds allocated on a per capita basis. The change in the formula was meant to address perceived 'unfaimess' in earlier infrastructure programs, which had provided meagre federal funding for the territories and First Nations.

The change in how federal funds were allocated as well as the program's stated goal to "ensure that all Canadians, whether they live in large, small or remote communities will share in the benefits of infrastructure investments" reveals the distributive politics underlying MRIF (Infrastructure Canada website). As Richard Soberman observed during his assessment of CIWP, ensuring 'faimess' in allocating federal funding is a decision based on political - not public policy - interests. Distributing federal funding for infrastructure investments regardless of 'need' fails to recognize the real disparity and priorities in infrastructure that should be of significance to the country. 'Equal' treatment is not necessarily synonymous with 'equitable' treatment.

The projects funded under MRIF were expected to "improve and increase the stock of core public infrastructure in areas such as water, wastewater, cultural (sic) and 
recreation (and) improve the quality of life and economic opportunities for smaller communities and First Nations" (Infrastructure Canada website). As an objective, providing federal funds for projects that increase (or in other words, 'expand') the stock of core infrastructure undermines the argument made by the FCM that funding from the senior levels of government was needed to address the 'infrastructure deficit.' While municipalities continue to argue that they need $\$ 60$ billion or more to deal with decaying infrastructure, they are far more interested in system expansion. The federal government's programs focus on capital accumulation rather than repair and rehabilitation or the provision of public services through alternative means.

\section{Program Results}

While the federal government will not be conducting a formal evaluation of MRIF until several more years, ${ }^{84}$ a preliminary examination of the database for the program has revealed some interesting trends. As was the case with CIWP and ICP, there was no minimum threshold for project funding. Municipalities requesting less than $\$ 10,000$ from the federal government for small infrastructure projects continue to receive their share of funds under the program.

Of the $\$ 203$ million in program funds that have now been committed (one-fifth of program funds), slightly more than one-third has been directed to wastewater projects, and one-quarter to water projects. Like the infrastructure programs that preceded it, however, most of the money was spent on new or expanded infrastructure rather than addressing the repair and rehabilitation of existing infrastructure (the 'infrastructure deficit'). Nearly half the funding for wastewater involved the construction of new or

\footnotetext{
${ }^{84}$ Under the terms and conditions for MRIF approved by Treasury Board, as the department responsible for administering the program Infrastructure Canada must carry out an evaluation within five years of signing the agreements with the provinces and territories.
} 
expanded infrastructure; over 92 per cent of the funding for water involved the construction of new or expanded infrastructure. Of the more than $\$ 20$ million in funding directed to tourism and recreation projects, 90 per cent involved the construction of new or expanded infrastructure.

While Budget 2003 cited the conclusion from the Sgro Report (officially known as “The Report of the Prime Minister's Caucus Task Force on Urban Issues”) that "infrastructure renewal tops the list of challenges faced by Canada's cities and communities," the program parameters for MRIF emphasized the importance of building new infrastructure rather than renewing existing stock. Using language similar to that employed in CSIF, the priority investments were those projects that were "vital to sustaining economic growth and supporting an enhanced quality of life in Canadian communities" (Infrastructure Canada website). 'Quality of life' is code language for those assets that are most coveted by politicians - cultural, tourism and recreational infrastructure. As Soberman observed during his evaluation of CIWP, "ribbon-cutting is almost always a preferable political activity to filling potholes or repairing underground water mains, at least in terms of media exposure."

\section{The Gas Tax and the Transit Fund (2003- )}

Shortly after the Martin government was sworn into office on December 2003, the federal government began negotiations to introduce a new approach to transferring funds for municipal infrastructure, touted as a key element of the 'New Deal for Cities and Communities.' The realization of the 'New Deal' was Martin's dream. He had lost his Cabinet position in the Chrétien government forty-eight hours after he delivered his 'New 
Deal' address to the FCM's convention on May 31, 2002. This speech was the catalyst that led to his ouster, particularly his declaration that, "Canada was in need of a New Deal for municipal governments... (and needed to) shed conventional wisdom ...mov(ing) beyond the tyranny of inertia that lies behind the objection, 'But that's the way it's always worked"' (Martin, 2003). Part of the New Deal involved sharing the federal excise tax on gasoline with municipal governments. Jean Chrétien and his Cabinet colleagues at the time were not prepared to 'shed conventional wisdom.'

Martin had cited the Sgro Report as well as a report on the state of municipalities from the TD Bank Financial Group - "A Choice Between Investing in Canada's Cities and Disinvesting in Canada's Future"- as sources for his newly declared public policy. Other members of the Chrétien government, on the other hand, objected to sharing federal revenues in this manner. Despite the concerted lobbying from mayors, Martin's successor as Finance Minister, John Manley, was reluctant to give up any of the gas tax collected by the federal government. He argued strongly against a transfer of these revenues in a speech delivered at the FCM's annual conference in 2003, precisely one year after the 'New Deal' address given by his predecessor:

First, it is not necessary for the federal government to do so in order for the provinces to grant fuel tax authority to municipalities. Second, it is not a solution that meets the needs of small and rural municipalities. Third, it is foregone revenue without accountability. And fourth, it undermines the vital partnership that we must foster between and among levels of government" (Manley, 2003).

Following the swearing in of his government, Paul Martin immediately launched his 'New Deal' agenda. In a repetition of the action taken two years earlier to create the Office of Infrastructure as part of PCO, Paul Martin created a Parliamentary Secretary within his government's Ministry to assist him. He also changed the machinery of 
government, establishing a "Cities Secretariat" bureaucracy within PCO to support work on the New Deal. The architecture for the deal making that would eventually involve billions of dollars in more funding for infrastructure would again be orchestrated through Privy Council Office, the Prime Minister's department and the Cabinet Secretariat.

In March 2004, the Budget committed the Government of Canada to a 'New Deal for Cities and Communities':

Canadians do not live in markets nor raise their children in economies; they do so in neighbourhoods, in communities. It is here that public policy meets private lives. It is here that the decisions we make affect the lives Canadians lead ...We need to ensure that Canada's communities provide a quality of life second to none ... Clearly, the Government of Canada is prepared to play its role and contribute its share. But a New Deal is not just about federal transfers of fiscal resources. It's about a transformative new partnership, involving all levels of governmentfederal, provincial and municipal. It's about doing things differently and doing things better (Canada, 2004, 13-14).

The language in the Budget - particularly the references to municipalities having status as 'partners' with the senior levels of government - brings to mind the sentiments expressed in Puppets on a Shoestring published thirty years earlier by the Canadian Federation of Mayors and Municipalities. Although local governments are responsible for infrastructure needs that reflect local public policy choices and decisions, the Martin Liberal government was proposing to set a course that would fundamentally change this. In July 2004, a new Ministry was created that included the position of 'Minister of State (Infrastructure and Communities).' The machinery of government provided support through the creation of a new department: Infrastructure and Communities. ${ }^{85}$ While the mandate to pursue the New Deal was transferred from the Privy Council Office to the new Infrastructure and Communities Portfolio, according to machinery of

\footnotetext{
${ }^{85}$ Infrastructure Canada, as the department responsible for administering the infrastructure programs, was now called 'Infrastructure and Communities' with the addition of the Cities Secretariat.
} 
government protocol the lead minister for the New Deal was in fact the Prime Minister. ${ }^{86}$

\section{Gas Tax Fund: New Deal or Another Transfer Program?}

The Martin Liberals proposed to provide municipalities with a share of the revenue from the federal excise tax on gasoline. In Budget 2005 the federal government committed to transferring a total of $\$ 5$ billion of federal Gas Tax revenues over five years "to help fund local environmentally sustainable infrastructure" (Canada, 2005, 9). Pursuant to the NDP's agreement to support the 2005 Budget of the Liberal minority government, an additional $\$ 800$ million was made available to support municipal investments in public transit over a period of two years. ${ }^{87}$ As part of the 'New Deal for Cities and Communities' the Martin government also committed to renew and extend the Municipal and Rural, Strategic and Border infrastructure programs.

In a paper presented in June 2005 to the Annual Meeting of the Canadian Political Science Association, Tim Mau noted that Martin's 'New Deal' was more rhetoric than reality:

Martin came into office on the desire and promise to make history through transformative change; he aspired to lead the country towards great accomplishments, an ambition that the nation fully embraced. In the context of what has been achieved to date with respect to the 'New Deal,' Paul Martin has undeniably demonstrated political leadership. However, the measures he has adopted hardly constitute the type of grandiose policy changes that would warrant the 'New Deal' label. His leadership has been transactional at best, which has only resulted in public disappointment regarding what might have been.

Regrettably, Martin simply has not provided the robust leadership required to bring about historic or transformative change in the realm of urban policy (36).

\footnotetext{
${ }^{86} \mathrm{~A}$ Minister of State can be appointed to assist a Minister or to undertake responsibilities assigned by the Prime Minister. While a Minister of State does not have a portfolio independent of the Minister he or she assists, the Minister of State is a Cabinet colleague and peer, not a subordinate, of that Minister. Source: PCO “Governing Responsibly"(2004) http://www.pcobcp.gc.ca/default.asp?Language $=$ E\&Page $=$ publications $\& S u b=$ guidemin $\& D o c=$ guidemin e.htm $\# 1.1$ ${ }^{87}$ The NDP agreed to support the minority Liberal government's budget if it included more federal spending. This was one of the rare occasions when an opposition party was able to take credit for the introduction of an infrastructure program. Normally the political capital associated with such programs is accorded only to the party forming the government of the day.
} 
The transactional nature of the 'New Deal' approach is evident in the infrastructure programs that were associated with it. While it is still too early to assess fully the results of the Gas Tax Fund (GTF), it is possible to make some preliminary observations on the program's design. Under the GTF, $\$ 5$ billion will be transferred to municipal governments for eligible projects that typically include roadways and bridges, public transit, community energy systems, water supply and treatment systems, wastewater treatment and collection systems, and solid waste management.

"Capacity building" is another eligible component for funding under the program that aims to support municipalities through "projects and activities that strengthen the ability of a municipality to develop and implement Integrated Community Sustainability Plans" (see Table 5).

Table 5 - Gas Tax Fund 'Capacity Building'

\section{Purpose}

Eligible projects will increase local government capacity to undertake integrated sustainability planning.

\section{Objective}

Integrated community sustainability plans enhance or build upon existing planning instruments and processes including: regional growth strategies; community development plans; community plans; community energy planning; transportation plans; infrastructure development plans; liquid waste management plans; solid waste management plans; long-term cross-modal transportation plans; water conservation/demand management plans; drought management contingency plans; air quality plans; greenhouse gas reduction plans; energy conservation plans; implementing/planning innovative environmental technologies that support sustainability.

\section{Activities}

i) Collaboration: building partnerships and strategic alliances; participation; and consultation and outreach;

ii) Knowledge: use of new technology; research; and monitoring and evaluation;

iii) Integration: planning, policy development and implementation (e.g., environmental management systems, life cycle assessment).

Source: Agreements on the transfer of federal gas tax revenues under The New Deal for Cities and Communities, Infrastructure Canada website. 
Through the development of these plans, municipalities are expected "to take a long-term, integrated and strategic approach for these new (infrastructure) investments" (Infrastructure Canada, 2006, 28). However, the GTF agreements are unclear as to how the results of activities such as 'collaboration,' 'knowledge' and 'integration' will be measured. As well, while the federal government expects local governments to adopt a long-term, integrated and strategic approach in selecting projects that receive funding under the GTF, it has not yet developed a National Transportation Plan to guide its 'strategic' and 'sustainable' investments in highways.

While the GTF was designed to operate from 2005-2006 to 2009-2010, it intends to "enable municipalities to make the long-term financial commitments needed to address local needs such as containing urban sprawl and to invest in environmentally sustainable infrastructure that will contribute to the shared national outcomes of cleaner air, cleaner water and reduced greenhouse gas emissions" (Infrastructure Canada, 2006, 28). However, capital plans that are based on a five-year horizon are typically skewed to ensuring short-term results. To do otherwise would require a major shift of thinking from municipal politicians.

The expected results of the GTF and the indicators used to assess them are left to the discretion of 'partnership committees' responsible for administering each agreement. Given the claim that the GTF will involve investments in "environmentally sustainable municipal infrastructure" the lack of a standard framework of program measures is remarkable. However, the manner in which funds are allocated reveals the true intention of the program. Despite the significant amount of funding that is available under the GTF, the allocation of federal dollars is based on 'equity' rather than need or the potential 
impact of the infrastructure investment. The absurdity of the effort made to ensure 'equity' in distributing funding is evident in transfers of federal dollars to the smallest of 'municipalities.' In one province, for example, communities with populations of eleven (11) are identified as eligible recipients that will obtain $\$ 1,134$ from the federal government annually for the next five years. ${ }^{88}$

While the source of funding - using dedicated revenues from the gas tax - for the New Deal was a change from earlier infrastructure programs, the Gas Tax Fund retains elements of earlier federal infrastructure programs. It offers a shopping list of project categories that are eligible for funding and involves a transfer of revenues from the federal government to support these projects. Such an approach can hardly be categorized as 'transformative.' As Mintz and Roberts observed, “... while the gas tax transfer has made mayors happier politicians, it fails to achieve a 'cities agenda' whereby municipal governments are given greater responsibility for raising taxes to fund their expenditure responsibilities" $(2006,1)$.

While the Chrétien Liberals were eager to 'plant the flag' by displaying the Canada word-mark in as many communities as possible, with the introduction of the Gas Tax Fund, the Martin government took 'branding' to a new level. The agreements for the GTF included the stipulation that all "communications materials referring to the sharing of federal gas tax revenues with eligible recipients will recognize that this initiative forms part of the New Deal..." The 'New Deal' was an explicit reference to a policy linked to Paul Martin and the Liberal Party he headed. The Liberals - and later the Conservatives - appreciated the political capital generated by dispensing billions of dollars through

\footnotetext{
${ }^{88}$ Canada-Alberta Agreement On The Transfer Of Federal Gas Tax Revenues Under The New Deal For Cities And Communities, signed May 14, 2005.
} 
municipal infrastructure programs.

There is also a larger public policy question: is relying on gas tax to support municipal infrastructure supportive of the principles of sustainable development? Slack et al have argued that, "If the funds are earmarked for local roads and transit, a fuel tax can be viewed as a benefits tax"(42). Imposing consumption taxes on fuel and applying these revenues towards the required maintenance and repair of road transportation systems and the costs to operate public transit supports the concept of 'user pay,' which some provinces have already implemented. ${ }^{89}$ As well, consumption taxes can provide revenues that allow for the development of alternative forms of transportation. Those paying the tax understand what transportation choices are available to them but it is ultimately their choice to make. On the other hand, using gas tax as a general source of revenues for different types of municipal infrastructure sends a very different message there is no link between the consumer and the benefits realized.

Green and Veldhuis argue, however, that fuel-based funding of transportation is patently unfair:

...taxes on gasoline are broad-based, taking money from people who never use certain roads, and subsidizing other people who do....why should automobile drivers pay to subsidize the mobility of for-profit trucking firms who use and impose most of the wear on the highways they travel? (9)

They point out that tolls rather than fuel taxes offer better alternatives to pay for the ongoing maintenance of roads as well as ongoing environmental damage - such as air pollution, noise pollution and water pollution - occurring on individual highways.

While the gas tax revenues used to fund the GTF were to be applied ostensibly to

\footnotetext{
${ }^{89}$ Provincial governments in B.C., Alberta and Quebec had already implemented sharing their gas tax revenues with urban centres to support urban transit. The municipalities, however, have no say in the tax rate, which is determined solely by each province. The provinces collect the revenue and transfer it to the cities.
} 
support 'local environmentally sustainable infrastructure,' there is a nefarious aspect to this argument if gas tax serves as a general revenue source for municipalities. There is an incentive for municipalities to encourage greater consumption of gasoline in order to maximize the possible transfer of funds from the federal government. In other words, encouraging those in single passenger vehicles to use public transit would be counterproductive to being able to increase the revenues of municipal governments under the 'Gas Tax' agreement with the federal government. From the perspective of creating public policy in support of sustainable development, the 'New Deal's' Gas Tax Fund may in fact be the wrong deal.

\section{Public Transit Fund}

Budget 2005 established the Public Transit Fund (PTF), a new $\$ 800$ million infrastructure program (although the funding was subsequently reduced to $\$ 400$ million by the Harper Conservatives in Budget 2006.) While the stated purpose of the PTF was to fund transit projects that provided "improved and more flexible transportation options for Canadians, reduced congestion, improved quality of the environment, and less production (sic) of greenhouse gas emissions and airborne pollutants," the manner in which the funds were allocated reveals the real objective of the program. ${ }^{90}$ Funding was provided to any municipality that currently operated public transit and was allocated proportionally based on their public transit ridership as reported by the Canadian Urban Transit Association. As such, jurisdictions such as the Yukon and Prince Edward Island received funding for the transit operations of their major metropolitan centres. In B.C., several municipalities received less than $\$ 20,000$; in Ontario, municipalities received as

\footnotetext{
90 The "Agreements On The Transfer Of Funds For Public Transit" are available at Infrastructure Canada, http://www.infrastructure.gc.ca/communities-collectivites/index_e.shtml
} 
little as $\$ 182$ over two years. Clearly the 'need' for transit funding and the potential impact of these investments were irrelevant in the design of the program.

The allocation of funding for transit programs contrasts sharply with the federal government's assessment of the need for transit security. In November 2006, the Harper Conservatives announced " $\$ 37$ million in funding for the six highest-volume urban transit systems - Montreal, the National Capital Region, Toronto, Edmonton, Calgary and Vancouver - for high priority security projects including risk assessments, security plans, employee training programs, public awareness, and the upgrade of security equipment such as access control technology and lighting." ${ }^{91}$ While the federal government has traditionally applied 'fairness' in distributing funds for infrastructure, clearly the analysis of the need for funding under this policy was different: security trumped faimess.

\section{Public Transit Capital Trust}

While cutting in half the $\$ 800$ million in funding for the Public Transit Fund that had been provided under the previous Liberal/NPD Budget, in Budget 2006 the Harper Conservatives introduced a new instrument for transferring federal funding for transit as well as four other "short-term pressures." 92 Rather than creating a new program or adding funds to an existing program, the Budget provided \$900 million in "one-time additional funding" for transit as part of an envelope of funding for the provinces and territories that was described as a measure that focused on "Restoring Fiscal Balance in

\footnotetext{
${ }^{91}$ Government of Canada News Release, Transport Canada, November 14, 2006, http://www.tc.gc.ca/mediaroom/releases/nat/2006/06-h138e.htm

${ }^{92}$ Canada (2006a) "Funding Support to Provinces and Territories to Address Immediate Pressures," Chapter 3 - Building a Better Canada: Restoring Fiscal Balance in Canada. Emphasis added. The other areas of 'short term pressures' included post-secondary education infrastructure, affordable housing, northern housing, and off-reserve Aboriginal housing.
} 
Canada." The combined $\$ 1.3$ billion in funding for transit aimed to "strengthen and expand Canada's public transit systems from coast to coast to coast" (Finance Canada 2006 a).

The language used in Budget 2006 to describe the need for transit funding was a marked departure for the federal government. Federal resources would be now transferred to municipal governments in order to restore fiscal balance. The federal government was already funding capital improvements to municipal transit through several programs: the Infrastructure Canada Program; the Canada Strategic Infrastructure Fund; the Gas Tax Fund; the Municipal Rural Infrastructure Fund; the Public Transit Fund; and the Urban Transportation Showcase Program. ${ }^{93}$ However, rather than creating another infrastructure program and developing the associated overhead needed to administer it (negotiating and administering separate contribution agreements with each province and territory, establishing management committees for each jurisdiction to provide oversight for the agreements, approving individual projects, transferring funds for each project, monitoring and reporting results, and conducting audits), the Harper government saw the 'need' simply as a matter of 'restoring fiscal balance.'

According to the Budget, the purpose of the Public Transit Capital Trust (PTCT) was to provide $\$ 900$ million for the provinces and territories "to support capital investments in public transit infrastructure including rapid transit, transit buses, intelligent transportation systems and high occupancy vehicle and bicycle lanes" (Finance Canada, 2006 a). However, the signed Agreement for PTCT was less precise, stating that:

\footnotetext{
${ }^{93}$ For details on Urban Showcase see http://www.tc.gc.ca/programs/environment/utsp/menu.htm
} 
WHEREAS public transit plays an important role in reducing traffic congestion in urban areas, reducing carbon dioxide and other emissions, and making communities more liveable ... draw downs from the Trust Patrimony by the Beneficiaries ... (will) support ...capital investments in public transit infrastructure, both as a means to reduce traffic congestion and to reduce carbon dioxide and other emissions in order to contribute to Canada's climate change and environmental goals (Finance Canada, 2006 b).

The Agreement does not define the assets that are eligible for funding and does not describe Canada's climate change and environmental goals. The Agreement is also silent on what criteria would be used for measuring the results of capital investments that receive funding under the Trust. Unlike the infrastructure programs, there is no 'communications protocol' that requires the provinces and the territories to organize announcements and ribbon-cutting ceremonies that acknowledge the funds from the federal government.

Payments were made into "third party trusts for the benefit of provinces and territories ... (who then had) the flexibility to draw down funds as they require up to the end of the lifespan of each individual trust" (Canada, 2006 a) ${ }^{94}$ As beneficiaries under the Trust, the provinces and territories are entitled to each receive a per-capita share of funds that will be transferred annually over three years. While infrastructure programs such as the Public Transit Fund used the same allocation formula, unlike these programs the Trust does not define which municipalities are entitled to receive funding and how the funds are to be used. The Trust's policy objective - restoring fiscal balance - is unencumbered by the rhetoric found in the federal government's municipal infrastructure programs.

\footnotetext{
${ }^{94}$ The trustee - Computershare Trust Company of Canada - was a signatory to Trust Indenture and Agreements that established a Trust Patrimony for each of the five short-term pressures identified in the Budget. Computershare describes itself as "a leading financial market services and technology provider for the global securities industry." See http://www-us.computershare.com/
} 


\section{After a decade of municipal infrastructure programs ...}

A report prepared for the Privy Council Office in July 2003 examined the federal government's role in infrastructure investment in cities. Given the authors' findings, it is not surprising that the report has remained unpublished, hidden from public scrutiny. The authors conclude that, "existing federal investments in housing, transportation, and infrastructure are uncoordinated, haphazard and have actually encouraged urban sprawl." 95 The report found that:

the major infrastructure investments in cities are fragmented amongst various departments with little co-ordination ... At present, there are no mechanisms in place to ensure that federal infrastructure investments are not working at crosspurposes with one another, or to systematically make informed decisions based on a comprehensive understanding of the economic and environmental implications of an investment decision (Metropole, 18-19, added emphasis).

To illustrate this conclusion, the authors cited the federal government's practice of providing funding for transit while at the same time committing public funds for the expansion of local roads and highways.

The report also observed that the federal government employed an environmentally unfriendly approach through its incentives for new homebuyers who find cheaper housing predominantly on green-field lands, in low-density, single-use and auto-oriented areas. The report concluded that, "the net effect ... is to support development and travel patterns that are not consistent with environmental sustainability objectives" (Metropole, 21).

A report issued in 2005 by the Commissioner of the Environment and Sustainable

\footnotetext{
${ }^{95}$ Toronto Star, October 25, 2004. The report cited - "Investing in Canada's Cities: Renewing the Federal Role" - was written by Metropole Consultants. The report was not made public but was obtained by researcher Ken Rubin under the Access to Information Act. A first draft, identified as a "discussion paper" and dated July 14, 2003, is available at the Winnipeg Civic Environmental Committee's web site: http://www.mbeconetwork.org/civic/pdf/investing_canadas_cities.pdf
} 
Development also criticized the lack of cohesion among the federal government's policies and fiscal incentives available in various programs. In her report to the House of Commons, she concluded that, “...the government continues to talk a good line about sustainable development and sometimes commits financial resources, but often fails to adequately implement its own commitments" (Auditor General of Canada, 2005, 12).

In the years since Metropole's report was submitted to PCO, the federal government has continued to make major infrastructure investments that are at crosspurposes with one another, pouring billions of dollars into transit mega-projects while investing in large highway projects across the country. The reason for this contradictory and 'unsustainable' approach is implicit in the manner in which the federal government makes investment decisions. Decisions related to the funding allocated to municipal infrastructure programs - particularly the CSIF - have been 'ad hoc,' a practice that was sharply criticized by the Auditor General (1998). Decisions have been based on political expediency rather than policy. Clearly focused policy would appear to be anathema since it would curb the propensity of federal politicians - whether Liberal or Conservative - to choose spending opportunities that maximize their ability to raise political capital. ${ }^{96}$

An internal study ('operational review') carried out for Infrastructure Canada by Consulting and Audit Canada (CAC) raised concerns about the integrity of the policy framework of the department. While there are a number of policy objectives for each of the infrastructure programs administered by the department there were concerns that the

\footnotetext{
${ }^{96}$ Nowhere was this more evident than the transit announcement made by the Conservative PM Stephen Harper on March 6, 2007. He announced \$962 million in federal funding towards the extension of the TTC's Spadina subway line into the suburb of Vaughn, a route viewed as 'voter-lucrative' for the conservatives in the next federal election. The Chair of the TTC complained that he was 'frustrated' that the TTC didn't get to decide how the transit funding would be used: "If we have limited dollars there are better ways to service more people and get more riders - or better serve existing riders - than the York subway." (TTC Chair Adam Giambrone, quoted by the Toronto Star, March 6, 2007.)
} 
"inconsistent application of processes ... could potentially affect program integrity" (CAC, xiv). The report observed that there was "a gap in the area of strategic infrastructure policy analysis and development" and called on the management of the department to "articulate a vision for INFC (Infrastructure Canada) that brings clearer definition to the department's policy role" $(54$, xxiii).

The observations from CAC are rather remarkable given the department was mandated to administer programs that were ostensibly 'strategic.' The numerous policy objectives associated with the infrastructure programs (see Table 6) served as fodder for developing the rhetoric used in media lines about project announcements and in reporting on program results to parliamentarians. ${ }^{97}$ Rather than making investments in projects that were "of major national and regional significance" and selecting projects that were "vital to sustaining economic growth" the federal government was more interested in 'spending' and how this would affect public opinion before and during elections.

Metropole's observation in 2003 that major investment decisions about infrastructure spending are 'fragmented amongst various departments with little coordination' remains relevant. Since the election of the Martin Liberals, the 'Infrastructure and Communities' department - which combined Infrastructure Canada as well as the Cities Secretariat from PCO - has retained the overall lead in the administration of municipal programs. However, the department has continued to operate with two separate policy and communications branches and two operations branches, each

\footnotetext{
${ }^{97}$ The outcomes defined for the programs are rife with problems of attribution. For example, the indicators presented in the RMAF for the Strategic Fund for tourism projects (page 23) include: "change in \# of tourists that visit community/region;" and "change in average length of stay in community/region." The indicators for "investment and economic development - increase in economic performance" include: "economic development statistics (e.g. housing starts, property values employment rates and various indices of economic growth)." Attempts to attribute these results solely to municipal infrastructure projects funded by the federal government would be fallacious.
} 
responsible for negotiating and administering different transfer programs with the provinces and territories even though they are addressing the same municipal infrastructure (e.g. transit).

Table 6 - Objectives of the Municipal Infrastructure Programs

\begin{tabular}{|c|c|c|c|c|c|c|}
\hline Program Objective & CIWP $^{\prime}$ & $\mathrm{ICP}^{\mathrm{iI}}$ & CSIF $^{\text {iit }}$ & MRIF $^{\mathrm{iN}}$ & $\begin{array}{l}\text { Gas } \\
\text { Tax }^{\mathrm{V}}\end{array}$ & $\begin{array}{l}\text { Transit } \\
\text { Fund }^{\text {vi }}\end{array}$ \\
\hline \multicolumn{7}{|l|}{ Economic Impact } \\
\hline $\begin{array}{l}\text { Accelerate recovery of national } \\
\text { economy (short-and long-term } \\
\text { employment creation) }\end{array}$ & $\bullet$ & & & & & \\
\hline $\begin{array}{l}\text { Provide for timely and effective } \\
\text { employment creation and skills } \\
\text { development }\end{array}$ & $\bullet$ & & & & & \\
\hline $\begin{array}{l}\text { Improve national, provincial and } \\
\text { local economic competitiveness }\end{array}$ & $\bullet$ & & & & & \\
\hline $\begin{array}{l}\text { More efficient use of existing } \\
\text { infrastructure }\end{array}$ & & $\bullet$ & & & & \\
\hline $\begin{array}{l}\text { Support for long-term economic } \\
\text { growth. }\end{array}$ & & $\bullet$ & & & & \\
\hline $\begin{array}{l}\text { Increase innovation, and use new } \\
\text { approaches and best practices }\end{array}$ & & $\bullet$ & & & & \\
\hline $\begin{array}{l}\text { Increase economic activity including } \\
\text { tourism }\end{array}$ & & & $\bullet$ & & & \\
\hline More-effective urban development. & & & $\bullet$ & & & \\
\hline Improve economic opportunities & & & & $\bullet$ & $\bullet$ & \\
\hline $\begin{array}{l}\text { Safer and faster movement of people } \\
\text { and goods }\end{array}$ & & & $\bullet$ & $\bullet$ & $\bullet$ & $\bullet$ \\
\hline \multicolumn{7}{|l|}{ Quality of life } \\
\hline $\begin{array}{l}\text { Upgrade the quality of Canada's } \\
\text { physical infrastructure in local } \\
\text { communities }\end{array}$ & $\bullet$ & $\bullet$ & & & & \\
\hline $\begin{array}{l}\text { Improve and increase stock of core } \\
\text { public infrastructure in areas such as } \\
\text { water, wastewater, cultural and } \\
\text { recreation }\end{array}$ & & & & $\bullet$ & & \\
\hline Improve quality of life & & & & $\bullet$ & $\bullet$ & \\
\hline \multicolumn{7}{|l|}{ Environmental Impact } \\
\hline $\begin{array}{l}\text { Promote improved environmental } \\
\text { quality including the introduction of } \\
\text { environmentally sustainable practices } \\
\text { and technologies }\end{array}$ & $\bullet$ & - & $\bullet$ & $\bullet$ & $\bullet$ & $\bullet$ \\
\hline
\end{tabular}


In addition to Infrastructure and Communities, there are many other federal departments involved in municipal infrastructure: Canada Mortgage and Housing; Environment Canada; Health Canada; Finance Canada; Public Works and Government Services Canada; Transport Canada; Western Economic Development; Industry Canada; Canada Economic Development for the regions of Quebec; the Atlantic Canada Opportunities Agency; and Indian and Northern Affairs Canada. Given the array of municipal infrastructure programs created since 1993 and the billions of dollars that were and will continue to be transferred for local infrastructure projects, the overhead needed to manage these resources in the federal government is incongruous. As Kitchen observed, the administrative burden imposed by various federal programs - grant applications, media events, audit and reporting procedures - is particularly perverse for local governments:

Th(e) situation is compounded if the grant system includes many conditional grants from different sources, with varying formulas and criteria for each program. The overall result may be a maze of programs and bureaucracies that waste time and money. Jurisdictional confusion and operational complexities are major drawbacks to the use of conditional grant programs $(2002 \mathrm{~b}, 163)$.

Despite the federal government's intention in Budget 2007 to proceed with more spending for infrastructure, there is still an absence of a framework to guide its spending decisions. The federal government has yet to update its decades-old National Highway Transportation Policy and, as Lorinc observed, there is no national transit strategy, "setting (Canada) apart from virtually every other industrialized country" (238). While Toronto was the recent recipient of more federal largesse for a major subway expansion, the mayor recognizes that ad hoc funding is not the solution, observing that, "We need a national transit strategy" (Miller). 
Federal infrastructure programs continue to provide funding for new wastewater treatment facilities producing effluent that does not meet the standards required by Fish Habitat Protection And Pollution Prevention in the Fisheries Act. While encouraging municipal governments to adopt a long-term, integrated and strategic approach through the development of 'integrated community sustainability plans' that will guide their decision making about infrastructure, the federal government does not practice what it preaches.

The FCM has had political property rights to the municipal infrastructure 'problem' for two decades, dominating the way in which the issue was framed and acted upon. However, the FCM now acknowledges that, "the lack of a clear understanding of (the infrastructure deficit's) scope, or even agreement on a definition of infrastructure, makes rational solutions difficult" (FCM 2006, 37). While recognizing the value of the federal government's munificence in providing billions of dollars for municipal infrastructure, the FCM has admitted that the 'problem' has not been addressed:

...while ad hoc contributions from the federal government have been useful, they have not provided the long term structural solution needed to address the infrastructure deficit for good (2006, 38, emphasis added).

The FCM is now calling for "long-term funding for targeted infrastructure programs" as well as new approaches to deal with the structural problem of insufficient revenues for municipal governments. While transfers from senior levels of government to municipal governments may be useful by addressing short-term political needs, other alternatives could offer better results both in terms of generating adequate sources of revenue for infrastructure and providing clearer accountability for the expenditures of these revenues. In the next Chapter, these alternatives will be explored. 


\title{
CHAPTER 4
}

\section{THE EVOLVING MUNICIPAL 'PROBLEM'}

\author{
It appears that what is required is an institutional change in the way \\ public capital is funded and managed (Gillen, 68).
}

In the mid 1970s, municipal governments and their representative lobbyist - the Canadian Federation of Mayors and Municipalities - railed against what they saw as fiscal unfairness resulting from the improper distribution of public revenues in the Canadian federation. While the federal and provincial governments had access to a variety of revenue sources, municipal governments were limited to the non-growth property tax. The CFMM's polemic - Puppets on a Shoe String - argued for stronger, more autonomous municipal government in Canada that was less reliant on conditional provincial grants and had greater access to a wide range of tax revenues.

In the mid-1980s, the FCM shifted the 'needs talk' about the problems that municipalities were facing by focusing the political discourse on the need to address the growing infrastructure deficit. While the FCMM criticized the unfairness created by the imbalance in sharing of revenues within the Canadian federation, the FCM chose a very different path. It promoted a collaborative, tripartite solution to increase the resources available to municipal governments. The federal government obliged, initiating a series of municipal infrastructure programs that transferred funds for thousands of capital projects. After a decade of these programs, the FCM is now redefining the municipal 'problem' and is attempting to restructure the political discourse about ways to address it. 


\section{Reshaping The Discourse}

The discourse pertaining to the needs of municipal government has come full circle since the publication of Puppets on a Shoestring thirty years ago. In June 2006, the FCM produced "Building Prosperity from the Ground Up: Restoring Municipal Fiscal Balance," a publication that redefines the problem. Rather than a shortage of funds needed to address the 'infrastructure deficit,' the municipal problem is now being redefined more broadly. The FCM argues that municipalities are facing a problem that requires a structural solution:

Every day, as mayors and councillors, we see what needs to be done in our communities, but too often we do not have the resources to do it. We also know this is not just a problem for our individual community; it is national problem. And we know the need for a solution is urgent. The system is broken and the time has come to fix it. To fix this problem, we need to find the causes. We know the immediate cause: municipal governments have too few resources to meet their growing responsibilities $(2006$, iii).

While the problem described by the FCM resurrects the arguments presented in Puppets on a Shoestring, it doesn't include the vitriol blaming the provinces for the financial woes of municipal governments. The report - which the FCM refers to as its "contribution to the national conversation" - takes a more rational, less impassioned view in presenting arguments about "Canada's municipal imbalance," assigning cause to "urbanization and offloading" (an oblique, somewhat muted reference to the provinces as well as the federal government). The imbalance has occurred as a result of a revenue shortfall that, when combined with growing responsibilities, constitutes "a formula for financial crisis" (FCM, 2006, iii).

The FCM is calling for action in several areas as a means of addressing the "vertical fiscal imbalance," which it defines as a situation where "the fiscal capacity of 
one order of government is insufficient to sustain its spending responsibilities while the fiscal capacity of another order of government is greater than is needed to sustain its spending obligations" $(2006,6) .{ }^{98}$ Some of the FCM's proposals to restore municipal fiscal balance include additional transfers from senior levels of government, although these would not include the ad hoc approaches of past and current infrastructure programs. In order to eliminate the 'infrastructure deficit,' the FCM is now calling for the development of "a long-term legislative framework for sharing federal gas tax or other revenue and long-term funding for targeted infrastructure programs" (2006, 3, emphasis added).

The FCM does not explain what is meant by 'targeted' infrastructure other than saying that there is a need for programs that "ensure sustainable, adequate and predictable sources of revenue for investment in municipal infrastructure" $(2006,57)$. This vagueness is not inadvertent: the FCM is attempting to redefine what is meant by the infrastructure deficit. Rather than focussing efforts to address the deterioration of existing municipal infrastructure, the FCM is recasting the infrastructure deficit as a combination of the accumulated backlog of maintenance and rehabilitation, the current demands for new and expanded infrastructure and the expected demand for new assets as a result of population growth $(2006,34)$. One type of asset in particular - public transit - is cited as "a glaring manifestation of the infrastructure deficit" $(2006,3)$.

The FCM's latest interpretation of the infrastructure deficit is a significant

\footnotetext{
${ }^{98}$ The concept of fiscal imbalance has two dimensions that describe conditions in transfers between governments in federal countries. The first condition is 'vertical imbalance' when one level of government collects more revenue than it spends while another spends more revenue than it collects. The federal government addresses vertical imbalance when it collects revenue from all parts of the country and then returns it in the form of grants to all provinces. The second condition is 'horizontal imbalance' when richer provinces have the ability to raise more per capita revenue, and provide more or better services, than poorer provinces. Equalization addresses horizontal imbalance.
} 
departure from the original concept used during the 1980s when it referred to the "crisis" in the provision of public services that was occurring as a result of deteriorating public assets. Through this deft slight of hand the FCM is acknowledging the preference of municipal politicians for the smorgasboard approach of municipal infrastructure programs that provide funding for a variety of 'needs' and 'wants' and 'desires.'

The FCM also argues that there is a need to modernize the municipal fiscal framework by diversifying revenue tools that include "a more equitable sharing of fiscal resources among all orders of government." It recommends that "a long-term revenue sharing agreement be developed ... (that) would enable municipal governments to reduce their financial dependence on property taxes." The proposal also calls for changes in municipal practices in how municipal governments "plan for growth, price their services and generate revenues" $(2006,3)$.

While the FCM's solutions continue to refer to the need for resource transfers from the senior levels of government (although the transfers would be longer-term), as TD Economics and others have argued, such practices "fail the accountability test, in that funds are raised by one level of government, but spent by another" $(2002,3)$. There is also the risk of the impermanence associated with these types of arrangements: “...even fixed, multi-year grants are not appropriate for financing cities' ongoing needs, because they leave municipal governments at the mercy of shifting federal and provincial priorities" $(2002,3)$.

In their research on federal fiscal arrangements during the last sixty years, Bird and Vaillancourt found that the generosity of the federal government has waxed and waned in response to its own fiscal and political fortunes (243). In the late 1970's, Bird, 
Bucovetsky and Foot predicted that a decline in federal fiscal surpluses would severely curb the federal government's willingness to transfer its revenues to areas of provincial jurisdiction (Bird et al. cited in Bird and Vaillancourt, 243). The authors' prescience was validated during the 1980s when the federal government began a long period of retrenchment from fiscal transfers that was driven by the deteriorating fiscal health of the federal treasury and by increased provincial irritation - particularly in Quebec - to federal 'incursions' into their areas of responsibility.

The federal government's retrenchment from fiscal arrangements with the provinces accelerated during the mid 1990s shortly after the launch of its Program Review. ${ }^{99}$ As Paquet and Shepherd noted, "What was originally envisaged as a rethinking and reforming of the role of the state within Canada's governance system and the role of the federal government within it was already dwarfed by the end of 1994 to an exercise of federal expenditure reduction, and by the end of 1995 to an efficiency-seeking exercise" (32). Major reductions were made to all government spending, particularly federal transfers to the provinces.

Cuts to the federal share of costs for social programs had a cascading effect on the revenues and expenditures of provincial and municipal governments. Provincial transfers to municipalities were significantly reduced and responsibilities were off-loaded especially in Ontario - to local governments without compensatory revenues. ${ }^{100}$ As McMillan observed, municipalities have been particularly affected by the vagaries of fiscal arrangements with senior levels of government:

\footnotetext{
${ }^{99}$ The Treasury Board Secretariat web site provides details on Program Review and the impact on reductions in transfers to provinces. http://www.tbs-sct.gc.ca/report/gfc-gpc/gfc-gpc02_e.asp ${ }^{100}$ Mackenzie's analysis is particularly useful in this regard. He describes the development and financing of public services in Canada using Statistics Canada's national accounts data to track key measures of public revenue and expenditures at all three levels of government as a share of the total economy (GDP).
} 
...over the past decade, municipal government has been pressured by a fiscal squeeze. Most notable has been the sharp reduction in transfers by both the provincial and federal governments, from about 25 percent to 16.6 percent of municipal expenditures, as those governments imposed fiscal restraints to reduce or eliminate deficits and did so by shifting a part of their costs onto the municipalities. Reductions of a large magnitude occurred in all provinces but Quebec where transfers actually increased as a portion of municipal budgets (25).

With the return to a healthy federal treasury by the late 1990 s, the Chrétien Liberals began to use the federal government's 'spending power' ${ }^{101}$ as a means of dissipating annual surpluses. As Vaillancourt and Bird noted, "the return to fiscal solvency ... led to renewed federal attempts to, as it were, plant the flag" in areas of provincial jurisdiction (243). However, while both the provinces and municipalities are currently enjoying the spate of transfers from the federal government, the arrangement remains transitory. As Mississauga's long-serving mayor observed, transfers remain a "band-aid approach ... not a solution" (McCallion). Rather, a structural solution is needed to address the revenue shortfalls faced by municipal governments.

Other proposals put forward by the FCM that call for changes to the municipal fiscal framework and improved municipal practices related to the provision of services offer new ways of addressing the municipal 'problem.' These alternatives are particularly promising in terms of providing greater accountability and more effective management of public funds and assets.

\section{Modernizing the Fiscal Framework}

Over the past several decades, authors such as Silver, Kitchen, Slack, Mackenzie,

\footnotetext{
${ }^{101}$ Bird and Vaillancourt observe that "federal 'spending power' is usually understood to refer to the power of the federal government to pay money to people or institutions for purposes with respect to which the federal Parliament does not have the power to legislate" (193).
} 
McMillan, Mintz, Roberts, and Vining have carried out considerable research on the topic of municipal finance, many arguing that the municipalities are not getting their fair of public revenues. While some point to the 1970's are the tipping point for the crisis in municipal finances, in reality the fiscal squeeze on local governments started much earlier.

Historically, income tax was a key revenue source for municipalities. The provinces and municipalities levied income taxes more than 80 years before the federal government started accessing these revenues in $1917 .^{102}$ In his research on the development of personal income tax in Canada, Robert Clark ${ }^{103}$ found that:

income tax levied at the municipal level was, in absolute amounts, more important than the provincial income tax in every year up to and including $1930 \ldots$ (and was) imposed in Canada (at least until 1930) both because of the need for revenue and because of the conviction that without such a tax persons who could afford to make contributions to municipal finances would not be paying their fair share of municipal taxes (cited in Silver, 398-399).

As Kitchen observed, by the end of the 1930s, "some form of municipal income tax had been accepted by every province in Canada..." $(1982,781)$. As Silver points out, however, income tax was not administered uniformly as it "varied in form and rate and (was) often imposed at the same flat rate as the property tax" (399). While municipal governments relied on the revenues from personal and corporate income taxes, they suddenly and permanently lost access to them during World War II.

In 1941, the federal government proposed that each province 'rent out' its right to collect taxes as a means of supplementing revenues to pay for the war effort. Under the

\footnotetext{
${ }^{102}$ The Canadian government was a latecomer to the practice of levying income taxes. Like the U.S., the need to levy these taxes was driven by the need to pay for the costs of war. Federal income tax in Canada started in 1917 to pay for WWI. Congress imposed the first U.S. federal income tax in 1862 to finance the Union's waging of the Civil War.

${ }^{103}$ Robert Mills Clark's work was presented in his unpublished $\mathrm{PhD}$ dissertation, "Some Aspects of the Development of the Personal Income Tax in the Provinces and Municipalities of Canada up to 1930," Graduate School, Harvard University, 1948.
} 
Wartime Tax Rental Agreement, the provinces - as well as municipal governments temporarily renounced their rights under the Constitution to collect personal and corporate income taxes and succession duties. ${ }^{104}$ However, the provinces did not embrace the proposal eagerly. As La Forest notes, "throughout this period, several provinces remained uncomfortable with the idea of ceding taxation powers to the federal government, even as part of a temporary rental agreement" (28).

The Tax Rental Agreements were expected to expire in 1947 but endured as part of the post war reconstruction. In 1962, the provinces ended the practice of renting out their taxing powers and in 1967 resumed collecting their own taxes (La Forest, 31-32). However, at the end of the tax rental agreements with the federal government, the authority to levy income tax was never reinstated for municipal governments. As Kitchen observed, "Since the signing of the first agreement, no municipality in Canada has levied a municipal income tax. Indeed, current provincial legislation states that local governments cannot implement a municipal income tax" $(1982,781)$.

In an article published in the Canadian Tax Journal in the late 1960s, Silver observed that, "There is little doubt that municipal governments are rapidly approaching the limits of real property taxation and are under considerable pressure to find new sources of revenue" (404). More than forty years after Silver's warning of a potential municipal fiscal meltdown, municipal governments - apart from those in Manitoba that enjoy a revenue sharing arrangement with the province - continue to be deprived of the

\footnotetext{
${ }^{104}$ There were a series of Wartime Tax Rental Agreements: 1941-1947; 1947-1952; 1952-1957; $1957-$ 1962. For an overview of the terms of the agreements, see R.M. Burns, "The Acceptable Mean: The Tax Rental Agreements. 1941-62 (Toronto: Canadian Tax Foundation) 1980.
} 
revenues from income taxes. ${ }^{105}$

The origin of the shortfall in municipal revenues can be traced directly to the Wartime Tax Rental Agreements that removed income tax authority from municipal governments. In 1933, local governments accounted for 40 per cent of all government revenues, nearly as much as the federal government (42 per cent) and more than double that of the provinces (18 per cent). At the end of World War II, the Tax Rental Agreements had increased the federal government's share of all public revenues to 82 per cent (Bird and Vaillancourt, 208). As La Forest points out, while the shift in federal fiscal clout was driven initially by a need to pay the costs of the war and post-war reconstruction, the demand for a greater federal share of government revenues evolved into a very different agenda:

... the (federal) government considered it essential to centralize taxation power to promote the Keynesian economic policies which it had proposed to embark on, and which it followed with considerable success for a long time during the postwar period with a singlemindedness that was probably unmatched in any other country ... During the last stages of the post-war period Parliament markedly expanded its activities in what had previously been considered within the provincial sphere, notably in the welfare field, sometimes independently and sometimes in cooperation with the provinces... Such activity, of course, effected a profound reorientation of power in the Canadian federation in favour of the central authority (28-32).

This centralization has been consistent with what has taken place in other major industrialized countries during the twentieth century. As Lee observes, "The ideal of democracy may be the dispersion of power, but the tendency in democracies is the centralization of power; in politics centripetal forces dominate centrifugal forces" (1).

\footnotetext{
${ }^{105}$ Through a revenue sharing agreement, Manitoba transfers a portion of the revenues from provinciallevied personal and corporate income taxes to its municipalities as unconditional per capita grants $(2 \%$ and $1 \%$ respectively). While Manitoba is the only jurisdiction in the country to share its revenues from income tax, the arrangement nevertheless is a 'transfer' of revenues rather than a permanent sharing of tax points that would permit municipalities to levy their own income taxes. For details on the Manitoba arrangement, see http://www.gov.mb.ca/chc/press/top/2005/07/2005-07-27-02.html
} 
While the federal share of revenues eventually returned to pre-World War II levels ( 44 per cent) the provincial share increased to 45 per cent. Only 11 per cent of total government revenues are now allocated to local governments (Bird and Vaillancourt, 208). The FCM argues that the municipal share of revenues from taxes is even less. In calculating the municipal share of taxes - excluding other revenues - it argues that, "currently 50 cents of every tax dollar collected in Canada go to the federal government, while 42 cents go to provincial and territorial governments (while) (m)unicipal governments are left with just eight cents..." $(2006,2)$. TD Economics also examined the fiscal plight of municipalities, comparing their recent revenue growth with those of the senior levels of government. Between 1995 and 2001, the revenues for local governments increased by $14 \%$, far less than the $38 \%$ and $30 \%$ increases of the federal and provincial governments respectively.

During the past sixty years, while municipal governments have experienced a severe drop in their share of government revenues, they have faced an extensive and growing burden with respect to their responsibilities for providing public services and building the associated capital stock that is necessary to deliver them. The municipal share of public infrastructure increased from 30.9 percent in 1961 to 52.4 percent in 2002 (FCM, 2006, 36). The expansion in the stock of municipal assets was particularly rapid from 1955 to 1977, when investment in infrastructure grew at an annual rate of 4.8 per cent (FCM, 2006, 36). This period of intense capital investment closely matched Canada's population growth and rate of urbanization. As Tindal and Tindal note, “...Canada's urban growth since the end of World War II had exceeded that of any 
Western industrial nation and three-quarters of the nation's population was concentrated on less than one per cent of its land area" (2000, 71, citing Gertler).

The costs of infrastructure have increased dramatically as Canada's population shifted from rural communities to urban centers. Nearly eighty per cent of the population now lives in urban areas. Two-thirds of the country's population, employment and real output are located in twenty-seven Census Metropolitan Areas (CMAs). The fiscal pressure on cities and city-regions has been particularly difficult for the larger centers that are experiencing the effects of urban sprawl.

To pay for the increased need for services, municipal governments have relied heavily on property taxes as their primary source of revenue since the 1940 s. However, as TD Economics notes, property taxes “are inherently flawed as an instrument for funding cities' long-term needs" $(2002,2)$. Since they are based on the assessed value of property, these taxes are "only weakly related to ability to pay - which constrains governments' ability to raise tax rates to boost revenue." Deprived of access to revenues such as income and sales taxes that grow with the economy, municipal governments have continued to increase their revenues through suburban green-field development.

As Lorimer points out, Canada's postwar land-development industry was created by the federal government's industrial development policy:

The federal government decided that it wanted more than just house-builders and houses; it wanted to see a new kind of building industry, with large corporations each capable of producing a sizeable quantity of urban accommodation. The field was no longer to be the exclusive preserve of small-scale independent businessmen as it had been up to the war (16).

Federal policies provided special tax concessions that allowed developers to pay little or no tax on their profits (18). As well, Ottawa helped ensure the availability of the 
necessary investment capital to finance residential construction through financial institutions and investors: “...potential homeowners could get mortgage money to enable them to buy new suburban houses ... and developers could obtain mortgage funds to build rental properties" (18). As Lorimer observes, however, while federal policies were aimed at creating a building industry, this is not what in fact was created:

What they produced is a land development industry. A building industry, dominated by a few large, national, vertically and horizontally integrated corporations would make its money out of construction. The land development industry, however, makes most of its money not out of new buildings but rather out of urban land (19, emphasis in original).

The federal government's strategy had a significant impact in shaping the pattern of growth in municipalities, particularly urban centers. The federal role in land assembly and the provision of financial assistance for single-family homes reinforced the pattern of low-density sprawl. As Goldrick observed, the federal government used urban growth as a "prime instrument of public policy to stimulate and maintain high levels of economic activity" (cited in Tindal and Tindal, 2004, 75). As the economy soared, both the federal and provincial governments reaped the enormous benefits of increased revenues from personal and corporate income taxes.

While municipal governments had the primary role in providing the physical services needed to support economic development, they were denied access to the tax revenues generated by this growth. When property taxes became the principle source of their revenue after World War II, municipal governments relied on the development of 'green space' in order to increase their revenues. Tindal and Tindal point out that, as a consequence, municipal governments were held hostage to land developers, becoming "servants of the development industry that they were supposed to regulate" (citing 
Lorimer, 2004, 77). The taxing and financing policies of municipal governments were shaped to encourage land development that inevitably led to more urban sprawl. As Slack observed, the higher property taxes accrued through this approach to land development provided incentives to create less dense housing projects. However, municipal governments eventually discovered that the costs to build and maintain the infrastructure needed to provide public services in lower density configurations are much more expensive than those in high density housing (Slack, cited in Tindal and Tindal, 2004, 78).

Slack points out that the approach to land development in Canada has been costly. The unsustainable development of green fields and the consequences of increased urban sprawl have triggered a cascading effect on the costs of infrastructure needed to provide public services:

Fragmented governments in metropolitan areas encourage scattered, leap-frog development that may be more costly to serve. Low densities of urban development are not only more expensive than more compact forms of development, but also undermine those aspects of quality of place ...that flow from higher densities and mixed land uses (Slack et al, 2003, 18).

In her report to the Panel on the Role of Government, Slack observed that, when combined with their increased responsibilities, municipal governments are fast approaching a fiscal precipice:

Vibrant cities and city-regions do not have adequate resources to meet their growing expenditure requirements. Increased demands for services and infrastructure and the growing reliance on an inelastic property tax base, clearly threatens the future financial viability of the major city-regions. This situation is, at least to some extent, the result of a misalignment between expenditures and revenues. There is thus a need to revisit the allocation of expenditure responsibilities and revenues between the provincial government and its cities to ensure that there is an appropriate balance between them. Most significantly, funding social housing a portion ( $\mathrm{sic}$ ) of social services from property tax revenues needs to be reconsidered (Slack et al, 2003, 41, emphasis in original). 
There is clearly a need for a permanent injection of revenues that grow with the economy, particularly for cities and city-regions of the country. One such solution would involve reinstating municipal income tax. In his research on this issue in the early 1980 's, Kitchen argued that additional municipal revenues could be generated through increases to the residential portion of property taxes, although he admitted that such a policy would be highly unpopular. ${ }^{106}$ As for municipal income tax, he understood the basis for its popularity with local politicians:

“(f)rom a municipality's point of view, the revenue elasticity of the income tax is a major advantage.... Although it is recognized that there is no scientific basis for establishing an equitable tax that is unrelated to the value of the benefits received, it has generally been accepted that income, after allowance for exemptions and deductions, is the most acceptable base for measuring fairness or equity in the distribution of the tax burden (1982, 781-782).

In reviewing the experience of municipal taxation in the U.S., Kitchen concluded that, "any notion that (Canadian) municipalities might impose their own income tax ought to be quickly dispelled" $(1982,786)$. Rather, he suggested that municipal governments could 'piggyback' the administration of municipal income taxes onto the existing provincial income tax system.

Twenty years later, Kitchen remains cautious about a return to a municipal income tax regime, arguing that, "... the current practice in many developed countries, supported by most of the economic literature, is to lower reliance on income taxation and increase reliance on consumption-based taxes. This, it is argued, creates fewer distortions and reduces the deadweight costs associated with taxation" (2002 a, 173-174). Kitchen is

\footnotetext{
${ }^{106}$ See Harry M. Kitchen, "Property Taxation: Overutilized or Underutililzed?" in Canadian Tax Journal, Vol. 30 (July-August 1982), 610-17.
} 
more inclined to support a 'benefits-model' approach to paying for municipal services. ${ }^{107}$

Mintz and Roberts as well are not fans of increasing the tax authority for municipal governments. They note that expenditure and taxing powers vary from province to province and that “...no single solution for improving municipal financing is necessarily appropriate for Canada as a whole" (2). In their search for a financial model that would improve municipal financing and encourage greater independence and responsibility, they conclude that:

Giving additional taxing powers to municipalities seems to be an inviting idea for those wishing to see cities with powers similar to other levels of government ...we find that an additional tax field for municipalities in the provinces is generally not warranted, although it is important to provide municipalities with greater flexibility in financing their expenditure responsibilities (1).

However, Mintz and Roberts miss the point. Rather than creating a new tax field and increasing taxes, a preferred option for reinstating municipal income tax could be accommodated through the transfer of tax points from the federal government, thus restoring a revenue source that was removed in 1941. A transfer of federal tax points is more easily accommodated than a transfer from the provinces. As Kitchen observes, “...provincial governments have shown no interest in sharing the income tax with their municipal counterparts" (2002 b, 224). Silver also agrees that the federal government is better placed to help municipal governments:

It is probably unrealistic to think that municipalities in Canada could persuade their respective provincial legislatures to pass legislation enabling the municipalities to levy an income tax without causing the provinces to consider the overall income tax burden. The trend has been for the provinces to levy income taxes only to the extent that the federal government has made 'tax room' available to them and, presumably, the provinces would authorize a municipal income tax only if tax room were made available by the federal government for this tax (405).

${ }^{107}$ See Kitchen (2004), "Financing Local Government Capital Investment." 
Those who advocate the restoration of municipal income tax are not calling for a pan-Canadian, universal approach. Rather, there is a caveat to their endorsement of the concept. In researching this issue in 1948 , Robert Clark found that a municipal income tax "was impractical for rural areas and was most successful in larger cities" (cited in Silver, 399). More than fifty years later, Slack, Bourne and Gertler concur with Clark's conclusion:

It is not appropriate to give more taxing authority to all municipal jurisdictions in the province. Large cities and city-regions are best suited to take advantage of new taxing authority; smaller cities are unlikely to be able to raise sufficient revenues from some of these sources to make the effort worthwhile" $(2003,42$, emphasis in original).

Restoring municipal income tax would present administrative challenges. While a full exploration of these issues is outside the scope of this thesis, the following example illustrates the complexity that would be involved. ${ }^{108}$ Kitchen commented on the need to connect 'work-based' income with the underlying municipal services that support it: “(s)ince commuters clearly derive benefits from the provision of local services in the communities where they work, it could be expected that they should contribute toward the cost of providing the services that generate the benefits" $(1982,783)$. Calculating the costs of the benefits in the tax to be paid would be challenging. As Silver observed, “...Clark's study clearly indicates that the administrative aspect of a municipal income tax may well be the most important factor in determining the success of the tax" (399). Silver concluded that, since the administration of municipal income tax would not be efficient at the local level, it was preferable to have the tax administered on behalf of municipalities:

\footnotetext{
${ }^{108}$ Some examples of the complexities involved in the administration of municipal income tax include its structure, the rate, exemptions and deductions and who should pay (residents and non-residents).
} 
The general consensus based both on the Canadian and United States experience appears to be that much is to be gained by having the municipal income tax parallel the federal income tax. In fact, there is much to be said for having the municipal income tax administered by the federal government. It is clear that if this were done, both the cost of administration and the burdens on taxpayers would be reduced (402).

While there is a divergence of opinion about the need for municipal income tax, there is general agreement that there is a need to improve municipal financing and encourage greater independence and responsibility in municipal governments. Even dissenters who oppose municipal income tax - such as Mintz and Roberts - conclude that, "the key is to allocate appropriate expenditure and tax powers to municipalities, which would also have greater autonomy in choosing their tax policies" (1).

As McMillan points out, greater autonomy through decentralization or subsidiarity is a central feature of fiscal federalism. Responsibility for the delivery of services should be assigned to the lowest level of government that is capable of providing effective levels of service. Consequently, there needs to be "a close link between local public benefits and local public levies ... the benefit principle should prevail"(15-16). McMillan elaborates further on the cost of municipal services and the revenues necessary to pay for them, observing that:

Maintaining the close connection between municipal services and municipal costs requires that local residents be responsible for meeting the expenses of local services. That is, municipal governments set the tax rates and charges to be imposed on their citizens (and electorate) to finance the costs of the municipal services. Benefit related finance and local determination of local levies are fundamental criteria. Addition (sic) criteria widely cited as desirable for municipal revenue sources (and often others) are that they should be adequate, predictable, fair, visible, not exportable and easily administered (16).

The federal government has the opportunity to make the structural changes that are needed to modernize the fiscal framework for municipal governments, at least for 
those larger urban centers responsible for delivering municipal services for the majority of citizens. Rather than creating ad hoc programs that transfer revenues to municipalities, the federal government could provide municipal governments with the power to raise revenues on a more stable basis through a transfer of tax points. These revenues would be consistent with the principles of accountability and subsidiarity, allowing municipal governments to raise revenues "derived from the people who live and work in the municipality and who, presumably, have the primary responsibility for the financing of municipal services, (and) to bear the political burden of doing so" (Silver, 405). The federal government has the opportunity to restore 'balance' to fiscal federalism.

\section{Changing municipal practices}

While increasing the revenues that are available to municipal governments - such as those derived from income tax - would provide a more stable tax base to pay for public services, there is still a need to revise municipal practices in several areas.

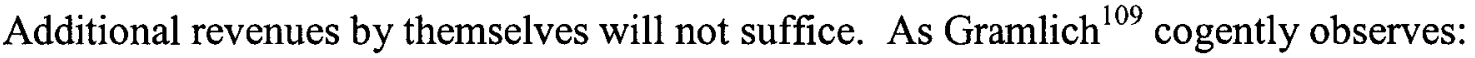
...the most important question involving infrastructure investment is not whether there has been a shortage of infrastructure investment, but rather whether government policies regarding infrastructure investment should be changed (1180-1181).

Much of the development of municipalities has involved an unsustainable approach to land use, leading to urban sprawl. The FCM acknowledges that there is a need to change municipal practices that relate to how municipal governments plan for growth, price their

\footnotetext{
${ }^{109}$ Gramlich was professor of economics and public policy at the University of Michigan, later appointed as Chairman of the Board, and Governor, US Federal Reserve Board.
} 
services and generate revenues. However, the FCM's proposal is short on details in this regard. There are specific measures that can be taken to improve municipal practices in three areas: integrated asset management; better demand management of services; and alternative service delivery. We will explore each of these issues briefly.

\section{Integrated Asset Management}

Publicly owned and operated infrastructure that is used in the delivery of municipal services collectively constitutes the most significant component of public wealth. However, on the other side of the public ledger, this infrastructure also represents a massive liability, the value of which is unknown. As was discussed earlier in Chapter 1, few municipal governments in Canada have accurate and comprehensive information on the condition of their public infrastructure and even less have a consistent approach in managing and preserving these assets to ensure their full service value. The absence of credible information about these public assets has led to a rather bizarre state of affairs in Canada where various proponents asking for more cash from senior levels of government compete to establish a new value of the municipal 'infrastructure deficit' based on little credible evidence. The reason for the "unclear portrait of the actual costs and impact," as Vander Ploeg and others have observed, is due to the lack of a 'systems' approach to asset management that uses fact-based information on the assessment of the current condition of municipal infrastructure and the costs to maintain it.

The lack of credible information about the state of public assets is particularly troublesome when attempts are made to assess the overall fiscal health of municipalities. As Kitchen and Slack observed,

...from a fiscal perspective, Canadian municipalities appear to be quite healthy. It may be, however, that municipal accounting practices do not tell the whole story. 
The overall health of our municipalities has less to do with balancing their budgets, which they are required to do by law in any event, than with the adequacy of the services that are being provided and the current state of municipal infrastructure ("Trends in Public Finance" in FCM, 2006, 54).

The absence of reliable information about the condition of municipal infrastructure and its associated financial liabilities can be overcome, but only through the application of standardized tools and techniques that will allow municipalities to determine the condition of their assets and then predict their remaining service life. Such action would allow municipal decision makers to cost the value of their infrastructure and prioritize the maintenance and capital renewal for these assets.

Some efforts are underway in Canada to encourage municipal governments to adopt a systems approach to managing their public infrastructure assets. In 2000, the federal government provided start-up funds for the development of the National Guide to Sustainable Municipal Infrastructure: Innovations and Best Practices (“InfraGuide"), a compendium of "proven state-of-the-art methodologies for municipal infrastructure planning, design, construction, management, assessment, maintenance and rehabilitation that consider the local economic, environmental and social dimensions that contribute to sustainable communities for municipal infrastructure planning, construction, maintenance and repair." ${ }^{110}$ InfraGuide relied on a broad network of volunteers - a community of practice - from diverse areas of society whose goal is to share or transfer knowledge to advance learning that improves decision-making related to municipal infrastructure.

While the billions of dollars allocated by the federal government's municipal infrastructure programs largely focused on building new assets, the rather small amount

\footnotetext{
${ }^{110}$ InfraGuide Website, http://www.infraguide.ca/aboutUs/StrategicDocuments_dyn.asp
} 
of funding for InfraGuide ${ }^{111}$ was directed at municipal 'capacity-building' by improving the decision-making related to managing existing public assets. By applying the tools created through InfraGuide - such as the knowledge products dealing with asset management and data management software for asset management - municipal governments can improve their decision-making by developing credible and reliable information pertaining to their infrastructure. While the focus on capacity building at the municipal level is particularly important, there are also recognized subsidiary benefits: better data about the state of local infrastructure is useful to other levels of government and key stakeholders.

Unlike the federal government's infrastructure programs, however, InfraGuide provided no direct funding to local governments and therefore offered little 'political capital' to federal politicians. The decision of the Harper Conservatives in early 2007 to refuse further funding for the initiative is evidence of InfraGuide's low rate of return in providing opportunities for retail politics and associated political capital. Despite the Tories decision to kill the initiative, municipal governments remain very supportive of this initiative and continue to use the products that were created.

\section{Demand management for municipal services}

The provision of municipal services is not a cost free exercise, although, as Soberman observed, the attitude of many members of the public would indicate otherwise: "infrastructure and adequate standards of service have long been treated as public goods to be provided by government, usually at no direct charge or charges that are far less than actual cost" (Vol.1, 2). Traditionally, the approach used by municipal

\footnotetext{
${ }^{111}$ The federal government initially contributed $\$ 12.5$ million towards InfraGuide in two phases, starting in 2001.
} 
governments to charge users of a particular service - the provision of potable water for example - has hidden the actual costs. As Brubaker observed, “(p)oliticized decision making in the public sector distorts the relationship between prices and costs and encourages subsidies to various interest groups" (2001, 2-3). Rather than accounting for the full costs to operate and maintain the system of production (treatment) and delivery (the distribution system) municipal governments have often used revenues from property taxes to offset costs. As a consequence, low municipal water prices have contributed to excessive use of this resource - Canadians are among the biggest users of water in the world. ${ }^{112}$

While some improvements have occurred through the introduction of mandatory full-cost pricing for municipal water and wastewater services, ${ }^{113}$ Gillen believes that fundamental changes are still needed in the way public capital is funded and managed in Canada. He challenges municipal practices that under-price the costs of providing public services, arguing that they are not sustainable:

The disconnect between user payments and investment has led to too much public capital in most cases and not enough in others... The single most important change (that is needed) would be to charge user fees, thereby addressing questions of revenue, allocation, spillovers, shortages type and politics (68).

He also points out that the current system of financing roads and highways has contributed to urban sprawl and that, "what is needed is a closer pricing and funding link between urban areas which pay for benefits that are strictly urban in nature and respond to local costs" (68). This view is shared by Kitchen, who champions the practice of

\footnotetext{
112 According to data from Environment Canada, municipal water prices in Canada are a fraction of that charged in other countries. See http://www.ec.gc.ca/water/images/manage/use/a4f3e.htm .

${ }^{113}$ In 2002, the Ontario government passed the Sustainable Water and Sewage Systems Act (Bill 175), which called for municipalities to quantify the full costs for their water and sewage systems and then prepare a cost recovery plan.
} 
earmarking fuel taxes as a 'benefit-based tax' and suggests that the revenues should be applied to funding roads and public transit $(2002 \mathrm{~b}, 230)$. This approach is clearly at odds with the federal government's current Gas Tax Fund agreements, which provide a cornucopia approach that permits these revenues to be used for a variety of infrastructure projects. Kitchen also promotes the idea of 'piggybacking' the administration of fuel taxes, but suggests that municipalities - rather than the provinces and the federal government - should be allowed to set their own fuel tax rate. ${ }^{114}$

The cost of maintaining and expanding transportation systems in municipalities particularly roads - consumes a huge portion of public revenues. As Vander Ploeg points out, "pavement ... has a notoriously short lifespan" (7). While many urban centers face ongoing pressures to expand roadways and construct new highways, they are having great difficulty in maintaining their existing transportation assets. As Lorinc observes, the federal government's current solution to the transportation woes in urban centers encouraged by more funding - emphasizes the need for capital accumulation such as that involving expansions of public transit:

In coming years, Canadian governments will expend billions on new transit investments intended to reduce highway congestion, improve air quality, and enhance urban quality of life. But none of it will pay off unless the three levels of government figure out how to coordinate these transit investments with local land-use decisions. Absent such planning, we'll have a suburban landscape littered with pricey white elephants, while the older downtown transit systems deteriorate as their infrastructure continues to age and their traditional peak-hour riders find jobs that can be reached only by car (247).

While some transportation demand practices have been introduced - such as the creation of High Occupancy Vehicle (HOV) lanes - as a means of reducing congestion

\footnotetext{
${ }^{114}$ In the U.S., municipalities have the authority to levy fuel taxes. As Kitchen points out, the revenues from these taxes are usually earmarked for local roads and public transit or are intended to replace grants that the state formerly provided for local transit and roads.
} 
during peak periods, there is a remarkable aversion by municipal politicians to introducing pricing measures. As Lorinc observes, “(a)lthough highways and urban thoroughfares serve as the circulatory systems of modern urban economies, Canadian governments seem to believe that these infrastructure assets operate outside the laws of supply and demand ... there is no fee for service" (241). As Clifford Winston remarked succinctly, "Road pricing should be the weapon of choice" (2005). Green and Velhuis also make a strong case for the use of tolls:

It would seem intuitive to anyone outside of government that people should only pay for the services they use. And transportation most certainly can be funded in fairer ways that provide better incentives for responsible use of highways (9).

Road taxes or tolls on key corridors would encourage alternate means of transportation and would be used to pay the real costs - fiscal and environmental - of the road system. ${ }^{115}$ Determining the full costs of these and other municipal services would then provide the opportunity to consider alternate means of delivering them. As Mississauga's mayor observed, "Cities have to adopt a business approach to the management of the city. We have to give value for tax dollars" (McCallion).

\section{Alternative Service Delivery}

In conjunction with the efforts of proponents who are calling for public solutions to the municipal 'infrastructure deficit,' a powerful business lobby has joined the fray by advocating the need to address the "infrastructure investment deficit" through partnerships with the private sector. The Canadian Council for Public-Private Partnerships has recast the problem facing municipal governments by arguing that local governments do not have the capability of paying for needed public services, especially

\footnotetext{
${ }^{115}$ Examples of these corridors include the Don Valley Parkway in Toronto, Highway 1 from the Port Mann Bridge in B.C.'s lower mainland and highways 13, 15 and 19 in Montreal.
} 
the infrastructure needed to deliver them. ${ }^{116}$ The Council cites a public opinion poll carried out over three years by Environics Research that found that "an overwhelming majority of Canadians (approaching nine in 10 this year) believe that their federal, provincial and municipal governments are not keeping pace with demand for new or improved public infrastructure and services" (1).

The Council has adapted the FCM's current definition of the infrastructure deficit, choosing to focus on the need for new or improved infrastructure rather than repair since they are primarily interested in providing solutions that involve building new assets. The Council argues that the infrastructure investment deficit can be addressed easily through public-private partnerships (P3s), which are also known as 'alternative financing and procurement' (AFP). Through these contractual arrangements, components of capital asset procurement and management - such as the design, construction, financing, and operation - are transferred to the private sector. In a municipality, the government's role in a P3 arrangement "changes from directing and managing assets to overseeing and ensuring that a pre-determined level of service quality is performed"' (T.D. Economics, 2006, i). The Council cites poll results that found that "a steadily increasing majority (64 per cent) of Canadians believe the time has come to put private sector finance and expertise to work on closing the infrastructure gap"(3). ${ }^{117}$

Not surprisingly, the business-friendly C.D. Howe Institute and TD Economics are strong advocates of $\mathrm{P} 3 \mathrm{~s}$, arguing that the private sector's expertise and capital should

\footnotetext{
${ }^{116}$ The Council is a member-sponsored organization whose objective is "to foster innovative forms of cooperation between the public sector - at the municipal, regional, provincial and federal levels - and the private sector, for the benefit of all Canadians." http://www.pppcouncil.ca/issues_infraDeficit.asp\#Civil 117 The types of assets that were considered as potential P3 partnerships included among others the financing and construction of public hospitals, the construction and maintenance of roads, the operation of public water treatment and sewage treatment facilities, the construction of public recreation facilities and the operation of public transit systems.
} 
be used in delivering public services in partnership with government. Proponents of P3s cite the paucity in existing approaches to managing publicly owed and operated municipal infrastructure:

Planning cycles in traditional procurement have often been based on a short horizon, resulting in sub-optimal maintenance and rehabilitation being carried out. In contrast, P3s encourage a 'life-cycle' approach to planning and budgeting through the use of a long-term contract, the inclusion of maintenance costs and the requirement that the asset remains in a good state of repair (T.D. Economics, 2006, i-ii).

Mintz (the CEO of the C.D. Howe institute) argues that sources of revenue from the private sector can supplement public revenues in order to meet public infrastructure needs. At the same time, however, he acknowledges that there is a need to understand the public and private roles in developing infrastructure, and where the public role rests in 'filling in market gaps' in infrastructure provision:

A significant part of the decision requires determining the cost versus benefit of public investment in infrastructure; the presumptive good from correctly making that determination flows from sensible tradeoffs between present costs and future benefits (foreward to Vining and Richards).

Increasingly, major Canadian pension funds and institutional investors are lobbying governments for the opportunity to finance and develop public infrastructure. As an article in the National Post recently pointed out, potential investors are "clamouring to find attractive infrastructure investments, yet such opportunities are lacking for them in Canada" (Homer). While Canadians have invested heavily abroad, they have lacked access to the domestic infrastructure market.

The Minister of Finance promoted the concept of P3's in public infrastructure in the 2006 Economic and Financial Update (Canada, 2006 b). As one of the "Five Canadian Advantages," the federal government touted "Canada's Infrastructure 
Advantage (that) will create modern, world-class infrastrncture to ensure the seamless flow of people, goods and services across our roads and bridges, through our ports and gateways, and via our public transit" (Canada, $2006 \mathrm{~b}, 11) .{ }^{118}$ The federal government has pledged that its "core challenge" will be to ensure that any funding for infrastructure has "maximum impact ...by taking advantage of innovative financing sources through public-private partnerships (P3s)." Towards this aim, the federal government has committed to creating a "federal P3 office that will facilitate a broader use of P3s in Canadian infrastructure projects ... (and) will encourage the development and use of P3 best practices by requiring that $\mathrm{P} 3 \mathrm{~s}$ be given consideration in larger infrastructure investments that receive federal program funding" (68). The federal government claims that, "greater use of P3s will also provide opportunities for Canadian pension funds and other investors to participate in infrastructure projects here in Canada rather than being forced to look abroad, as is often the case now." (67).

Since the federal government is twice removed from the governance responsible for municipal assets, the prospect of the federal government providing expertise to municipal governments in the use of P3s is highly suspect. However, the Harper government's enthusiasm for P3s is not surprising, given the Minister of Finance's previous role in provincial politics. The Harris government in Ontario promoted the concept of P3s in municipal and provincial infrastructure projects through SuperBuild Corporation, the province's infrastructure investment agency. ${ }^{119}$ The political mantra from SuperBuild included the commitment that "public-private investment partnerships

\footnotetext{
118 The "advantages" other than infrastructure include tax, fiscal, entrepreneurial, and knowledge.

119 SuperBuild failed to meet the expectations of its political masters, who had campaigned to double public infrastructure investment in the province, from $\$ 10$ billion to $\$ 20$ billion, through investments from the private sector. Soon after their electoral win in 2003, the Liberals dismantled the agency.
} 
will play a big role in eliminating Ontario's infrastructure deficit" (Ontario SuperBuild Corporation, 7, added emphasis). Despite the bravado, little progress was made in the promotion of $\mathrm{P} 3 \mathrm{~s}$. As Brubaker points out:

Although enhancing private sector involvement was clearly provincial policy, the government failed to communicate the policy to municipalities or the public. It did little to implement the policy... The government's professed but seldom publicized commitment to privatization has had little impact on municipal decisions ..."(2).

Brubaker argues that, as an alternative approach to the delivery of public services, P3s offer clear benefits beyond the possibility of infusing huge amounts of private sector funds into public infrastructure. When regulating themselves, governments are too often restrained by conflicts-of-interest: "governments cannot effectively regulate utilities that they own, operate, or finance" (25). Consequently, using P3s in the provision of certain public services (such as those that involve utilities) offer improved accountability.

The lessons from the demise of Ontario's SuperBuild may prove instructive for the federal government. Rather than continuing the enthusiasm for P3s that was embedded in the Harris and Eve governments, the McGuinty government has toned down the rhetoric. Ontario's Ministry of Public Infrastructure Renewal (PIR) now refers more cautiously to "finding the best models for financing infrastructure projects." In a speech given in 2005, the Minister of PIR stated,

Let me be unequivocal about this: Core public assets such as hospitals, schools and water systems will always be publicly owned, publicly controlled and publicly accountable. There is no transfer of public ownership in alternative financing and procurement. To suggest otherwise would be fearmongering.

P3s should not be marketed as a panacea. There are risks that must be addressed, particularly for municipal governments who are unfamiliar with the many complexities that can arise from these types of arrangements. As Brubaker observes, the need for 
capacity building is key to assist municipal government in dealing with their 'fear of the unknown:'

They want more information on what works and what doesn't. They want case studies, templates for successful contracts, and models for creating and managing partnerships and assessing their success or failure. As their counterparts both within and beyond Canada's borders accumulate and share experience, they will doubtless gain confidence (41).

The publication of a best practice published by InfraGuide - "Alternative Funding Mechanisms" - has made some progress in this regard. In examining the "funding partnerships" that have occurred in Canadian municipalities, InfraGuide cites a number of examples, pointing out that while "funding partnerships appear to be prevalent ... (they) are not yet (a) common practice in all municipalities." However, this may be interpreted as a positive sign. Rather than adopting P3s as a 'common practice,' it is better to consider the public interest in each case. A significant part of the decision must determine whether the costs to proceed with private sector capital financing, operation and maintenance of an infrastructure project (as well as the associated risks) can withstand the scrutiny of public interest. Unfortunately, the development of a Public Sector Comparator - one of the principal tools that should be used in appraising the 'value for money' of $\mathrm{P} 3$ investment proposals - is often given short shrift. ${ }^{120}$

While senior levels of government debate the merits of various approaches to financing public infrastructure, the outcome of this debate must focus on the best interests of communities and the residents who use and pay for these assets and the services that are provided. For the past several decades, the creation of public infrastructure has been

\footnotetext{
${ }^{120}$ The federally-funded transit project in Vancouver - the Canada Line, formerly known as RAV - is a case in point. The decision to use a P3 in the project was politically motivated: the public sector comparator was an afterthought completed during - rather than before - the procurement process.
} 
spurred by the political imperatives associated with 'capital accumulation,' expanding more of what already exists rather than considering alternatives that may offer more sustainable solutions from a fiscal and environmental perspective. As Vining and Weimer observed, infrastructure projects provide valuable political capital, "attracting constituency votes because they are location specific and tangible" (147-48). Citizens would be better served if governments made decisions about land use, levels of service and infrastructure that fully integrated the principles of sustainable development. The degree to which the senior levels of government provide support in this regard is crucial. 


\section{CHAPTER 5}

\section{CONCLUSION}

Often what matters most about a problem is not whether it can be solved or managed but how it will be solved ( $\mathrm{Pal}, 112$, emphasis in original).

In this thesis we set out to explore why, since 1993, successive Liberal and Conservative governments have transferred - and continue to transfer - billions of dollars of federal revenues in support of municipal capital projects. At various times during the last century, the federal government provided short-term loans and grants for local public works projects as a means of spurring job creation during difficult economic times.

During the past decade, however, federal involvement in financing municipal infrastructure evolved into much more than intermittent spending aimed at economic stimulus. Making 'investments' in municipal infrastructure became entrenched as a policy of the federal government and a key part of the political agendas of both the Liberal and Conservative Parties.

During the 1980's, a coalition led by the Federation of Canadian Municipalities developed and executed a well-crafted strategy that sought to convince the federal government that there was an ongoing need to transfer revenues to support municipal infrastructure. However, seeking 'conditional grants' from senior levels of government was clearly not the FCM's first option. The organization had lobbied unsuccessfully to have municipalities recognized as a distinct order of government under the Constitution although, as Tolley and Young point out, the real quest was "largely motivated by their 
search for practical ways and means to meet the increasing demands upon their fiscal resources" (1).

The FCM's predecessor - the Canadian Federation of Mayors and Municipalities - had argued vociferously during the 1970s against what it called "unfairness" in the federal system that deprived municipal governments of needed financial resources. "Puppets on a Shoe String" cited a growing gap between local revenues and expenditures and concluded that the fiscal imbalance and deficits of local governments were not the result of careless spending. Rather, they were due to a structural defect in the Canadian finance system that was perpetuating the unbalanced distribution of revenues. While the federal and provincial governments had access to a variety of revenue sources, local governments were limited to the non-growth property tax. The CFMM argued for stronger, more autonomous municipal government in Canada with less reliance on conditional grants and greater access to a wide range of tax revenues.

While the CFMM and the FCM were unsuccessful in bringing about structural changes through constitutional and fiscal remedies, municipal governments were finally rewarded when the federal government agreed in 1993 to create a program that transferred more than $\$ 2$ billion from its revenues to support local infrastructure. As Andrew and Morrison pointed out, "the federal infrastructure program ... came into being in 1994 because there was an understanding that there was a need for spending on infrastructure" (2002, 240, emphasis added).

As Rochefort and Cobb observed, in developing public policy "controversy often surrounds how a given issue will be understood" $(1993,56)$. The creation of the Canada Infrastructure Works Program illustrates this point very well. The federal government 
agreed to transfer resources for infrastructure projects largely as a means of providing an economic stimulus during the height of the 1990s recession. During the 1993 election, in reading the 'national mood' the Chretién Liberals had sensed the need for an injection of federal spending:

The idea goes by different names - the national mood, the climate of the country, changes in public opinion, or broad social movements. But common to all of these labels is the notion that a rather large number of people out in the country are thinking along certain commons lines, that this national mood changes from one time to another in discernable ways, and that these changes in mood or climate have important impacts on policy agendas and policy outcomes (Pal, 117, citing J.W. Kingdon, 1995, Agendas, Alternatives, and Public Policies).

As Andrew and Morrison also pointed out, the concept of spending on local infrastructure greatly appealed to Chrétien's political style: "The Liberals wanted to be seen as pragmatic populists ..." $(1995,112)$.

In the mid 1980s the FCM began to lobby the federal government for funding that would address the 'infrastructure deficit,' a concept that was not then or now easily defined or understood. The efforts of the FCM and its coalition partners to control the political discourse about the 'infrastructure deficit' illustrates the observation made by Hilgarter and Bosk that "specialized community of operatives" often use their ability to advance theories and data on which policies are based (cited in Rochefort and Cobb, 1994, 14). Using language that held little meaning - the 'infrastructure debt' or 'deficit' - became a powerful tool in the shaping discourse during the struggle to politicize and control the issue.

The FCM attempted to provide an overview of the "condition and funding adequacy" of Canada's municipal infrastructure in a report published in 1985, although the findings included the results of a self-serving survey that employed a questionable 
methodology. The report conceded that providing a credible measure of the 'infrastructure deficit' was an impossible task given the lack of available data that was needed to substantiate it. Nevertheless, the FCM proceeded to shape the issue's meaning much like Stone had described: it was a "struggle to control interpretations and images..."(282).

The FCM's report recommended that there was a "most urgent ... need to develop financial strategies for infrastructure repair and replacement" and pointed out that, "(while) Canadians have reason to be concerned about the condition of their municipal infrastructure, Canada, unlike the United Stated or Europe, has given virtually no public attention to it" $(1985,10)$. The report encouraged the FCM and its members to begin to increase public awareness of the issue (5). The organization immediately acted on the recommendations, setting out to convince the nation that the 'infrastructure deficit' was serious and required funding from the federal government to deal with it. Much like Fraser's description of the "politics of needs," the FCM became involved in a series of struggles that began with validating the infrastructure 'issue' as a matter of legitimate political concern (240). The organization then interpreted the need and, in doing so, gained the power to define it and determine what would satisfy it.

The FCM initially focused its arguments for federal funding based on the need to deal with deteriorating municipal infrastructure, claiming that many public assets were fast approaching the end of their life cycle. The organization argued that municipal governments were unable to cope financially with the mounting backlog of maintenance and replacement. During the last thirteen years, the federal government transferred billions of dollars ostensibly to assist municipalities with their 'infrastructure deficit.' 
However, as was discussed in Chapter 3, much of the funding was directed to infrastructure expansion rather than repair. As well, there continues to be little credible data about the current state of public assets that are owned by municipalities across the country. Most municipal governments continue to lack a 'systems' approach to managing public infrastructure that uses fact-based information on the assessment of its current condition and the costs to maintain it.

Twenty years after launching a lobby to secure federal funding for municipal infrastructure, the FCM is recasting the 'infrastructure deficit' as a combination of an accumulated backlog of maintenance and rehabilitation, current demands for new and expanded infrastructure and expected demands for new assets as a result of population growth $(2006,34)$. In order to eliminate the 'infrastructure deficit,' the FCM is now . calling for "a long-term legislative framework for sharing federal gas tax or other revenue and long-term funding for targeted infrastructure programs" $(2006,3)$. In other words, while the 'need' has been redefined, the FCM's 'solution' still includes federal transfers.

As TD Economics and others have argued, revenue transfers from the senior levels of government "fail the accountability test, in that funds are raised by one level of government, but spent by another" $(2002,3)$. There is also considerable risk to these types of arrangements: “...even fixed, multi-year grants are not appropriate for financing cities' ongoing needs, because they leave municipal governments at the mercy of shifting federal and provincial priorities" $(2002,3)$. Both provincial and municipal governments experienced first hand the impermanence of revenue transfers from Ottawa, most recently during the efforts of the federal government to address the deficit by significantly 
reducing transfer payments after Budget 1995.

Unlike its predecessor, the CFMM, the FCM's discussion of the fiscal challenges facing municipal governments and the possible solutions to these problems has been rather deferential. While the CFMM argued for stronger, more autonomous municipal government in Canada with less reliance on revenue transfers and greater access to a wide range of tax revenues, the FCM has referred only to the need to 'modernize' the municipal fiscal framework by diversifying revenue tools that include "a more equitable sharing of fiscal resources among all orders of government" (2006, 3, emphasis added). As was discussed in Chapter 4, clearly there is a need to revisit the fundamental issue of taxation and access to these revenues, including the restoration of personal and corporate income tax authority that was removed from municipal governments during World War II. As Slack observes:

...there is widespread agreement that municipalities do not have sufficient revenue-raising tools to meet their expenditure responsibilities ...Trends in municipal finance over the last 16 years show that municipal spending has been increasing steadily but that the revenue-raising tools available to municipal governments have not changed (2006, 2-3).

Fixing the 'structural defect' in the Canadian finance system will significantly reduce the need for federal transfers for municipal infrastructure. ${ }^{121}$

The federal government's traditional 'incidental' provision of funding for municipal infrastructure during times of economic uncertainty evolved considerably during the past decade to a point where it now has an ongoing financing role in

\footnotetext{
${ }^{121}$ A limited number of transfers may still be required in keeping with section $92(10)$ of the Constitution Act which provides a role for the federal government in infrastructure that connects provinces to each other as well as that which, "although wholly situate within the Province, are before or after their Execution declared by the Parliament of Canada to be for the general Advantage of Canada or for the Advantage of Two or more of the Provinces." The authority given to the federal government in this regard can be seen as one that deals with infrastructure 'spill overs'- public works that support national rather than provincial or local interest.
} 
supporting local capital projects. From our examination of the federal government's response to the 'need for spending' on municipal infrastructure, however, it is clear that it chose a path that was paved with intentions based on political rather than policy needs. Rather than addressing the revenues required by municipal governments from a 'structural' and long-term perspective, the federal government chose to make 'infrastructure investments' that served short-term political interests. As Massimo Bergamini, the FCM's Director of Policy recently observed:

... it is ad hoc and unpredictable short-term funding that muddies accountability and obscures objectives because of short-term political considerations .... Planning and building municipal infrastructure efficiently and cost-effectively requires long-term certainty and predictability. Without it, short-term thinking takes over, leading to projects that may not make the best use of limited tax dollars (FCM, 2007).

A recent report published by the Conference Board of Canada - "Mission Possible: Successful Canadian Cities"- observed that, "The critical elements that link initiatives to successful outcomes for cities are missing: a long-term agenda for sustainable cities and a strategy to coordinate policies between and within governments" (99). The absence of a longer-term federal agenda has served the transactional focus of the infrastructure programs, which fund projects in a 'policy vacuum.'

Distributive politics provided the underpinning for the allocation of federal revenues in several of the infrastructure programs, which used a per capita funding formula. This approach has been found wanting by the Conference Board, which recommends that the federal and provincial governments cease this practice: "Funding programs are stuck in the 'equal treatment for all' approach and ignore the particular needs of Canada's major cities" (99).

For many years, the federal government has adopted an ad hoc approach in 
selecting projects for funding under its highway infrastructure programs, a practice severely criticized by the Auditor General of Canada (1998). The ad hoc approach was carried over into the federal government's municipal infrastructure programs, which also focus on 'projects' rather than long-term solutions. The absence of a policy framework for federal highway and municipal infrastructure programs has facilitated political opportunism that, in the words of Bergamini, is nourished by "one-off, politically-driven announcements" (FCM, 2007).

As Pal observed, “...we presume that our governments are doing more than rambling, that they have a plan, that their journeys and their destinations are guided by policy" (13). At the same time, there is a need to ensure 'coherence,' which Colebatch describes as "the assumption that all the bits of the action fit together, that they form part of an organized whole, a single system(;) ... policy has to do with how this system is (or should be) steered" (cited in Pal, 5). The federal government still does not have a coherent plan or 'urban agenda.' As Lorinc observed, “... tinkering is an apt description for how the upper levels of government have addressed the issue of declining infrastructure in Canada's hub cities..." (218).

The lack of a clear and focused policy framework has facilitated the use of billions of dollars in discretionary funding for political objectives. Liberal and Conservative governments have been more concerned with the visibility from infrastructure program spending and the ensuing political capital generated from the announcements of federal largesse. Stéphane Dion, current Leader of the Opposition and former minister in both the Chrétien and Martin Liberal governments, recently castigated Prime Minister Stephen Harper for making a billion-dollar investment in transit 
infrastructure in Toronto. He chastised the Conservative PM for making "ad hoc announcements without any clear direction (and for) spending to try to seduce the Canadian people (sic)."122 His comments could apply equally to the practices of former Liberal governments.

During the past decade, the federal government's funding for municipal infrastructure has had little or no impact at all on the nation. As McMillan points out, "While one can recognize the value of federal visibility from input into municipal projects affording broad local public benefit ... the national interest in and benefit from many of these investments is difficult to imagine"(19). Weingast, Shepsle and Johnson observe that the omnibus-like quality of distributive programs is rooted in their approach to making decisions on a project-by-project, locality-by-locality basis:

...geography is the hallmark of distributive politics: Programs and projects are geographically targeted, geographically fashioned, and may be independently varied. Importantly, geography is also the basis for political organization and representation (644).

Rather than addressing the structural fiscal imbalances facing municipal governments and focusing efforts to support a transformational change in the way public assets are funded and managed - changing how municipal governments plan for growth, price their services and generate revenues - the federal government chose to fund a myriad of infrastructure projects across the country. Rather than contributing to a transformative change in support of national interest - stiffening the economic sinews of the nation in a manner that is consistent with the principles of sustainable development the federal government has perpetuated existing, unsustainable practices in order to satisfy short-term political interest.

${ }^{122}$ CBC Radio, The House, interview with Kathleen Petty, broadcast on March 12, 2007. 
The federal government's approach to funding municipal infrastructure supporting capital accumulation rather than preserving assets and considering alternative service delivery - was much like its own 'unsustainable' infrastructure practices. Public Works Minister Michael Fortier recently observed on the federal government's actions in this regard, stating that, " 370 federal buildings have been accumulated 'by accident' (sic)... We don't have the expertise and the ambition to be real estate owners, nor should we ... We don't need to own bricks and mortar to deliver services" (Barrera). The same could be said about the ongoing accumulative practices of municipalities.

The cash transfers from the federal government - although eagerly accepted by municipal politicians - have not helped to create the fundamental change processes needed to make sustainable development a reality at the local community level. While transfers from the federal level of government are often likened to the "glue" that holds the federation together - addressing inequities among regions, correcting externalities, and cementing pacts among provincial or regional coalitions - infrastructure programs have served more oblique political objectives, à la distributive politics. As the Liberals understood - and the Tories are now learning - the transfers of federal largesse act less as glue and more as grease for the political machine.

Regardless of whether the federal government is led by Liberals or Conservatives, the media events and announcements related to these infrastructure projects provide valuable political capital. As Lorinc wryly observes:

No self-respecting politician is immune from the allure of a feel-good ribboncutting, and such investments have generated a steady stream of press conferences, where MPs, MPPs, and MLAs can gather to glad hand and have their pictures taken (220). 
Through the creation of an elaborate bureaucracy designed to build political capital by maximizing opportunities for retail politics, the infrastructure programs have provided the ultimate political catnip. Federal politicians are able to present themselves as munificent benefactors of federal largesse, spending billions of dollars of public revenues on assets for which they have absolutely no accountability. 


\section{BIBLIOGRAPHY}

Andrew, Caroline. 2001. "The shame of (ignoring) the cities," Journal of Canadian Studies, Winter Volume 35, No 4 (Winter 2001) pp.100-110.

Andrew, Caroline and Jeff Morrison. 1995. "Canada Infrastructure Works: Between 'Pick and Shovels' and the Information Highway," in How Ottawa Spends 199596: Mid-Life Crises, Susan D. Phillips, ed. Ottawa: Carleton University Press. 2002. "Infrastructure," in Urban Policy Issues, Canadian Perspectives, 2d. Edmund P. Fowler and David Siegel, eds. Toronto: Oxford University Press.

Andrew, Caroline, Katherine Graham and Susan D. Phillips. 2002. Urban Affairs: back on the policy agenda. Montreal: McGill-Queen's University Press.

Association of Consulting Engineers of Canada. 2002. "Tackling the National Infrastructure Deficit," Pre-Budget Submission to the House of Commons Standing Committee on Finance. http://www.acec.ca/

Atkinson, Michael M. and Williams D. Coleman. 1989. The State, Business and Industrial Change in Canada. University of Toronto Press: Toronto.

Auditor General of Canada. 1996. Chapter 26, "Canada Infrastructure Works Program: Lessons Learned," Report of the Auditor General of Canada, November.

. 1998. Chapter 25, "Transport Canada: Investment in December.

Highways 1987-88 to 1996-97," Report of the Auditor General of Canada, 1999. Chapter 17, "Canada Infrastructure Works Program: Phase II and Follow-up of Phase I Audit," Report of the Auditor General of Canada, September.

2003. Chapter 3, Report of the Commissioner of the

Environment and Sustainable Development.

Sustainable Development.

2005. Report of the Commissioner of the Environment and

Barrera, Jorge. 2007. "9 Up for grabs as repair bill goes through the roof," The Ottawa Sun, March 6, 2007.

Barry, John and Robyn Eckersley, eds. 2005. The State and the Global Ecological Crisis. Cambridge: MIT Press. 
Basford, Ron. 1972. Speech on Housing and Urban Affairs, extract from Hansard, Commons Debates, March 13, 1972, available at the Centre for Urban and Community Studies, University of Toronto. http://www.urbancentre.utoronto.ca/pdfs/policyarchives/1972Basford.pdf

Bickers, Kenneth N and Robert M. Stein. 1994. "Response to Barry Weingast's Reflections," Political Research Quarterly, Vol. 47, No. 2, June, 329-333.

Bird, Richard M. 1994. "Decentralizing Infrastructure: For Good or Ill?" Policy Research Working Paper 1258, A background paper for World Development Report 1994 on infrastructure. Washington, D.C.: World Bank. http://ideas.repec.org/p/wbk/wbrwps/1258.html

Bird, Richard M. and Francois Vaillancourt. 2006. "Changing with the Times: Success, Failure and Inertia in Canadian Federal Arrangements, 1945-2002," in Federalism and Economic Reform - International Perspectives, Jessica S. Wallack and T.N. Srinivasan. Cambridge: Cambridge University Press.

Brubaker, Elizabeth. 2001.“The Promise of Privatization," Prepared for the Walkerton Inquiry, April 2001. http://www.environmentprobe.org/EnviroProbe/pubs/walkerton.pdf

. 2003. "Revisiting Water and Wastewater Utility Privatization," Prepared for the Government of Ontario Panel on the Role of Government Presented at "Public Goals, Private Means" Research Colloquium Faculty of Law, University of Toronto, October 3, 2003. http://www.lawlib.utoronto.ca/investing/reports/rp39.pdf

Bunting, Trudi and Pierre Filion, eds. 2000. Canadian Cities in Transition, the twentyfirst century, 2d. Toronto: Oxford University Press.

Canada. 1970. House of Commons Debates, October 8, 1970.

. 1982. Budget Speech of the Minister of Finance, Allan Maceachen, Hansard, Commons Debates, June 28, 1982.

. 1994. Speech from the Throne of the $35^{\text {th }}$ Parliament, First Session January 17, 1994.

. 1995. Estimates of the Government of Canada, 1995-96 Part III Expenditure Plan - Transport Canada.

1997. Budget Speech, Building the Future for Canadians, February 18, 1997.

. 1999. Speech from the Throne of the $36^{\text {th }}$ Parliament, Second Session,

October 12, 1999. 
. 2000. Budget Speech, Better finances, better lives, February 28, 2000.

. 2001 a). Speech from the Throne of the 37th Parliament, First Session, January 29, 2001.

. $2001 \mathrm{~b}$ ). Budget Speech, Securing progress in an uncertain world,

December 10, 2001.

.2005. Budget Speech, Delivering on commitments, February 23, 2005

. 2006 a). Budget Speech, Focusing on priorities, May 2, 2006

. 2006 b). Economic and Financial Update, Advantage Canada: Building a Strong Economy for Canadians, November 23, 2006.

http://www.fin.gc.ca/ec2006/pdf/plane.pdf

Canadian Council for Public-Private Partnerships. 2006. "Trends in Canadian Support for Public-Private Partnerships," Surveys conducted by Environics Research Group. http://www.pppcouncil.ca/pdf/p3poll_2006.pdf

Caplan, David. 2005. "Closing Remarks to the Standing Committee on Estimates by the Minister of Public Infrastructure Renewal," September 25, 2005. http://www.pir.gov.on.ca/english/news/speeches/s20050927.htm

Carver, Humphrey. 1948. "Houses for Canadians: A Study of Housing Problems in the Toronto Area," available at the Centre for Urban and Community Studies, University of Toronto. http://www.urbancentre.utoronto.ca/pdfs/policyarchives/ 1948HumphreyCarver.pdf

Chrétien, Jean. 1998. Address to the annual meeting of the Federation of Canadian Municipalities, June 8.

Clark, W. Harold. 1950. "Towards Better Communities," Address given to the National Conference Community Planning Association of Canada, Ottawa, October 6, 1950. Available at the Centre for Urban and Community Studies, University of Toronto. http://www.urbancentre.utoronto.ca/pdfs/policyarchives/ 1950HaroldClark.pdf

Clarkson, Stephen. 2002. Globalization, Uncle Sam and Us: Neoconservatism, and the Canadian State. Toronto: University of Toronto Press.

Collin, Jean-Pierre and Jacques Léveillée. 2003. "Municipal organization in Canada: Tradition and transformation, Varying from province to province," in collaboration with Mathieu Rivard and Mélanie Robertson. Institut de Ciències Polítiques i Socials (ICPS) of the Universitat Autònoma de Barcelone, September. http://www.diba.es/innovacio/fitxers/ML_Canada.pdf 
Conference Board of Canada. 2007. "Mission Possible: Successful Canadian Cities," The Canada Project Final Report, Vol. III. http://www.conferenceboard.ca/ Consulting and Audit Canada. 2005. "Final Report: Infrastructure Canada Operational Review," February. (unpublished).

Cox, Wendell. 2004. "How Transportation Policy in Toronto is Making Things Worse," Fraser Forum, November.

Durant, Robert E., Daniel J. Fiorino and Rosemary O'Leary, eds. 2004. Environmental Governance Reconsidered Challenges, Choices, and Opportunities. Cambridge: MIT Press.

Eggleton, Arthur. 1995. “Infrastructure in Canada," Policy Options, January-February.

Ellen, Ingrid Gould and Amy Ellen Schwartz. 2000. "No Easy Answers: Cautionary Notes for Competitive Cities," The Brookings Review, Summer 2000 Vol.18 No.3 pp. 42-45 http://www.brookings.edu/press/review/summer2000/ellen.htm

Federation of Canadian Municipalities/Canadian Federation of Mayors and Municipalities. 1976. "Puppets on a Shoestring: The Effects on Municipal Government of Canada's System of Public Finance," Ottawa, April.

Federation of Canadian Municipalities. 1985. "Municipal Infrastructure in Canada: Physical Condition and Funding Adequacy," Vol 4, \#1, January.

http://www.fcm.ca/english/qol/qol1999.pdf

. 1999. "Quality of Life Reporting System," May.

2004-2005.”

. 2005. "Green Municipal Fund Annual Report

. 2006. "Building Prosperity from the Ground Up:

Restoring Municipal Fiscal Balance," June. http://www.fcm.ca/english/advocacy/fiscalim.pdf

2007. Letter to the editor, The Ottawa Citizen, Massimo Bergamini, Director, policy, advocacy and communications, March 11, 2007.

Federation of Canadian Municipalities and the Department of Civil Engineering And Applied Mechanics, McGill University. 1996. "Report on the State of Municipal Infrastructure in Canada," January.

Filion, Pierre, Trudi Bunting, and Len Gertler. 2000.“Cities and Transition: Changing Patterns of Urban Growth and Form in Canada," in Canadian Cities in Transition, the twenty-first century. 2d. Bunting and Filion, eds. 
Finance Canada. 2006 a). News Release, "Taking Public Transit is Now More Affordable in Canada," July 5, 2006 http://www.fin.gc.ca/news06/06-031e.html

. 2006 b). "Trust Indenture and Agreement creating the Public Transit Capital Trust," March 31, 2006. Unpublished.

Fowler, Edmund P. and David Siegel, eds. 2002 Urban Policy Issues, Canadian Perspectives, 2d. Toronto: Oxford University Press.

Fraser, Nancy. 1989. "Talking about Needs: Interpretive Contests as Political Conflicts in Welfare-State Societies," Ethics, Vol. 99, No. 2 (Jan.), 291-313.

Gillen, David. 2001. "Public Capital, Productivity, and the Linkages to the Economy: Transportation Infrastructure" in Building the Future: issues in public infrastructure in Canada, Vining and Richards, eds.

Globe and Mail. October 31, 1944. "Home Ownership - In Town or Suburb."

Gomery, John H. 2006. "Who is Responsible? Fact Finding Report," Commission of Inquiry into the Sponsorship Program \& Advertising Activities, Volume 1. Ottawa: Public Works and Government Services Canada.

Gramlich, Edward M. 1994. "Infrastructure Investment: A Review Essay," Journal of Economic Literature, Vol. 32, No. 3 (Sept., 1994), pp 1176-1196.

Green, Kenneth and Niels Veldhuis. 2004. "Tolls, not taxes," Fraser Forum, November.

Harcourt, Mike. 2006 "From Restless Communities to Resilient Places: Building a Stronger Future for all Canadians," Final report of the External Advisory Committee on Cities and Communities. http://www.infrastructure.gc.ca/eacccccevc/alt_formats/pdf/eaccc_rep_ccevc_rap_e.pdf

Homer, Gordon J. 2006. "Why not P3?: Public-private partnerships could help solve our crisis of ailing infrastructure," National Post, Thursday July 6.

Hulten, Charles R. and Robert M. Schwab, "Infrastructure and Economic Performance: What the Data Really Show," in Mintz and Preston, eds., Infrastructure and Competitiveness.

InfraGuide. 2002. "Alernative Funding Mechanisms," Innovations and Best Practices http://www.infraguide.ca/bestPractices/default_e.asp

. 2003. "Developing Levels of Service - A Best Practice," Innovations and Best Practices. 
Infrastructure Canada. 2002. News Release: "Allan Rock Releases Parameters For New Infrastructure Programs," August 9, 2002.

. 2003 a). News Release: "Government Of Canada Announces Parameters For Infrastructure Funds," July 22, 2003.

2003 b). "Canada's Municipal Development And Loan Fund

(1963-1966)," Research Note, November 2003.

.2004. "Results-based Management and Accountability Framework (RMAF) for the Canada Strategic Fund for the Funds Identified in Budget 2001 and Budget 2003." March 5, 2004. (unpublished).

2006. "Report on Plans and Priorities 2006-2007."

http://www.infrastructure.gc.ca/alt_formats/pdf/RPP-Colour_e.pdf

Kitchen, Harry. 1982. “Municipal Income Taxation - A Revenue Alternative?” Canadian Tax Journal, vol. XXX, no. 5, September-October.

. 1995. "The Infrastructure Works Program: Some Economic Concerns," Policy Options, January-February.

. 2002 a. "Canadian Municipalities: Fiscal Trends and Sustainability," Canadian Tax Journal (2002) vol. 50, no 1 http://www.norfolkcounty.on.ca/ Contribute/doingbusiness/documents/2002ctj1_kitchen.pdf

. 2002 b. "Municipal revenue and expenditure issues in Canada." Toronto: Canadian Tax Foundation. Canadian Tax Paper \#107.

. 2003. "Physical Infrastructure and financing." Research paper prepared for the Panel of the Role of Government in Ontario, December 4, 2003. http://www.law-lib.utoronto.ca/investing/reports/rp44.pdf

. 2004. "Financing Local Government Capital Investment," August 2004, http://www.trentu.ca/economics/WorkingPapers/Financing\%20Capital\%20Invest ment.pdf

Kitchen, Harry M and Enid Slack. 2003. "Special Study: New Finance Options for Municipal Governments," Canadian Tax Journal, vol. 51, no. 6 http://www.ctf.ca/pdf/03ctjpdf/2003ctj6-kitchen.pdf

La Forest, Gérald Vincent. 1981. The Allocation of Taxing Power Under the Canadian Constitution. 2d. Canadian Tax Paper No. 65. Toronto: Canadian Tax Foundation. May.

Lafferty, William M and James Meadowcroft, eds. 1996. Democracy and the Environment: Problems and Prospects. Cheltenham: Edward Elgar. 
Lee, Dwight R. 1994. "Reverse Revenue Sharing: A Return to Fiscal Federalism." The Cato Journal. Vol. 14/ Issue 1 (Spring/Summer).

http://www.cato.org/pubs/journal/cj14n1-7.html

Liberal Party of Canada. 1993. "Creating Opportunity: The Liberal Plan for Canada" (Red Book I).

21 st Century” (Red Book II).

. 1997. "Securing our Future Together: Preparing Canada for the 2000. "Opportunity for all: The Liberal Plan for the Future of Canada" (Red Book III).

Lithwick, N.H. 1970. Urban Canada: Problems: Problems and Prospects. A report prepared for the Honourable R.K. Andras, Minister Responsible for Housing. Ottawa: CMHC.

Lorimer, James. 1978. The Developers. Toronto: James Lorimer.

Lorinc, John. 2006. The New City: How the Crisis In Canada's Urban Centres is reshaping the Nation. Toronto: Penguin.

Mackenzie, Hugh. 2006. "The Art of the Impossible: Fiscal Federalism and Fiscal Balance in Canada," Hugh Mackenzie, Canadian Centre for Policy Alternatives, July. http://www.policyalternatives.ca/documents/ National_Office_Pubs/2006/Fiscal_Federalism.pdf

McCallion Hazel. 2007. Panel presentation on TVO, The Agenda, broadcast March 8. 2007.

McCracken, Michael C. and Carl A. Sonnen, 1993. "Infrastructure and the Canadian Economy: The Macroeconomic Impacts," in Infrastructure and Competitiveness, Jack M. Mintz and Ross S. Preston, eds.

McMillan, Melville L. 2003. "Municipal Relations with the Federal and Provincial Governments: A Fiscal Perspective," April 2003. Prepared for the MunicipalProvincial-Federal Relations Conference, Queen's University, May 9-10, 2003. http://www.vrm.ca/documents/McMillan.pdf

Manley, John. 2003. "Speech by the Honourable John Manley, Deputy Prime Minister and Minister of Finance, to the Federation of Canadian Municipalities," June 1, 2003. http://www.fin.gc.ca/news03/03-027 1e.html

Marchaoui, Tarek M., Faouzi Tarkhani and Paul Warren. 2003. "Public Infrastructure in Canada: Where do we stand?" Statistics Canada.

http://www.statcan.ca/english/research/11-624-MIE/11-624-MIE2003005.pdf 
Martin, Paul. 2003. "Speech by the Honourable Paul Martin, Minister of Finance for Canada, to members of the Federation of Canadian Municipalities," May 31, 2002. http://www.fin.gc.ca/news02/02-046e.html

Mau, Tim. 2005. "Political Rhetoric or Genuine Leadership: An Assessment of the 'New Deal for Cities." http://www.cpsa-acsp.ca/papers-2005/Mau.pdf

Metropole Consultants. 2003. "Investing in Canada's Cities: Renewing the Federal Role.” Draft 1, July 14, 2003, available at the Winnipeg Civic Environmental Committee's web site: http://www.mbeconetwork.org/civic/pdf/ investing_canadas_cities.pdf

Miller, David. 2007. Panel presentation on TVO, The Agenda, broadcast March 8. 2007.

Mintz, Jack M. 2005.“New Deal for Cities,” Financial Post, June 28, 2005.

Mintz, Jack M. and Ross S. Preston, eds. 1993. Infrastructure and Competitiveness. Kingston: Queen's University Press.

Mintz, Jack M. and Tom Roberts. 2006."Running on Empty: A proposal to Improve City Finances," C.D. Howe, The Urban Papers, No. 226, February. http://www.cdhowe.org/pdf/commentary_226.pdf

Murray, Stuart. 2006. "Value for Money? Cautionary Lessons About P3s From British Columbia," Canadian Centre for Policy Alternatives, June. http://www.policyalternatives.ca/documents/BC_Office_Pubs/bc 2006/P3 value for_money.pdf

Ontario SuperBuild Corporation. 2000. "Building Ontario's Future: A SuperBuild Progress Report,” December.

Paehlke, Robert C. 2004. "Sustainability" in Environmental Governance Reconsidered Challenges, Choices, and Opportunities, Durant, Fiorino and O'Leary, eds.

Pal, Leslie A. 2006. Beyond Policy Analysis - Public Issue Management in Turbulent Times. 3d. Scarborough: Nelson Thomson Learning.

Paquet, Gilles and Robert Shepherd. 1996. "The Program Review Process: A deconstruction," in How Ottawa Spends 1996-97: "Life Under the Knife," Swimmer, ed.

Pastor, Robert A. 2001. Toward a North American Community - Lessons from the Old World for the New Washington D.C.: Institute for International Economics.

Privy Council Office, 2002. "Prime Minister announces changes in ministerial responsibility," News Release, August 7, 2002. 
Reevely, David. 2007. “Toronto's aggressive panhandler," The Ottawa Citizen, March 6, 2007.

Richards, John and Aidan R.Vining. 2001."Thinking about Infrastructure," in Building the Future: issues in public infrastructure in Canada, Vining and Richards, eds.

Rochefort, David A and Roger W. Cobb. 1993. "Problem definition, agenda access, and policy choice," Policy Studies Journal. Urbana: University of Illinois, Vol. 21, 56-71.

Rochefort, David A and Roger W. Cobb. 1994., eds., The Politics of Problem Definition: Shaping the Policy Agenda. Lawrence: University Press of Kansas.

Royal Bank of Canada. 1965. Newsletter: "Winter Work," November 1965, Vol. 46, No. 11, http://www.rbc.com/community/letter/november1965.html

Seymoar, Nola-Kate. 2004. "Planning for Long-term Urban Sustainability: A Guide to Frameworks and Tools," +30 Network.

http://www.sustainablecommunities.ca/files/PDF/30 A Guide to Frameworks a $\underline{\text { nd Tools final.pdf }}$

Sheltair Group, The. 2001."Green Municipalities: A Guide to Green Infrastructure for Canadian Municipalities," Prepared for the Federation of Canadian Municipalities. http://www.sustainablecommunities.ca/files/PDF/GreenGuide_Eng_Oct2002.pdf

Silver, Sheldon. 1968. "The feasibility of a Municipal Income Tax in Canada," Canadian Tax Journal, vol. XVI, no. 5, September-October.

Slack, Enid. 2006. "Fiscal Imbalance: The Case for Cities," Institute on Municipal Finance and Governance, Munk Centre for International Studies, University of Toronto. http://www.utoronto.ca/ mcis/imfg/pdf/municipal\%20fisal\%20imbalance\%20paper\%20Jun\%2006.pdf

Slack, Enid, Larry S. Bourne and Meric S. Gertler. 2003."Vibrant Cities And CityRegions: Responding To Emerging Challenges," Paper prepared for the Panel on the Role of Government, August 13, 2003, http://www.lawlib.utoronto.ca/investing/reports/rp17.pdf

Soberman, Richard M. 1996. "Taking Stock: A Review of the Canadian Infrastructure Works Program," conducted for The Canada Infrastructure Works Office, Treasury Board Secretariat, Ottawa: Canada (President of the TB). Volumes I and II. Unpublished. 
Stevenson, Don and Richard Gilbert. 2005. "Coping with Canadian federalism: the case of the Federation of Canadian Municipalities," Canadian Public Administration, Vol. 48, No. 4 (Winter).

Stone, Deborah. 1989.“Causal Stories and the Formation of Policy Agendas," Political Science Quarterly, Volume 104, number 2.

Swimmer, David. 1993. "An Overview of Infrastructure, its Measurement and Relation to Productivity and Economic Growth," in Infrastructure and Competitiveness, Mintz and Preston, eds.

Swimmer, Gene, ed. 1996. How Ottawa Spends, 1996-97: "Life Under the Knife." Ottawa: Carleton University Press.

TD Economics. 2002. Special Report: “A Choice Between Investing in Canada's Cities and Disinvesting in Canada's Future."

2004. "Mind the Gap: Finding the Money to Upgrade Canada's Aging Infrastructure," Special Report. http://www.td.com/economics/special/infra04.pdf

(2006). "Creating the Winning Conditions for Public-Private Partnerships (P3s) in Canada," Special Report. http://www.td.com/economics/special/db0606_p3s.pdf

Tindal, Richard C. and Susan Nobes Tindal. 2000. Local Government in Canada, 5d. Scarborough: Thomson Nelson.

Scarborough: Thomson Nelson.

2004. Local Government in Canada,6d.

Tolley, Erin and William R. Young. 1991. "Municipalities, The Constitution, and The Canadian Federal System," Political and Social Affairs Division, October 1991, Revised February 2001 Published by the Depositary Services Program, BP-276E. http://dsp-psd.pwgsc.gc.ca/Collection-R/LoPBdP/BP/bp276-e.htm\#Legislative

Urmetzer, Peter. 2003. From Free trade to Forced Trade. Toronto: Penguin Canada.

United Nations. 1992. "Agenda 21," Conference on Environment \& Development, Rio de Janerio, Brazil, June 3-14, 1992.

http://www.un.org/esa/sustdev/documents/agenda21/english/Agenda21.pdf

Vander Ploeg, Casey G. 2003."Municipal Infrastructure in Canada: Issues of terminology and Methodology," Canada West Foundation. Prepared for Infrastructure Canada. http://www.infrastructure.gc.ca/research-recherche/result/studiesrapports/rs05 e.shtm1 
Vanier, D.J. and S. Rahman. 2004. Municipal Infrastructure Investment Planning (MIIP) report, "Survey on Municipal Infrastructure Assets," National Research Council of Canada, Report No: B-5123.2.

Vining, Aidan R. and John Richards, eds. 2001.Building the Future: issues in public infrastructure in Canada. Toronto: C.D. Howe Institute.

Vining, Aidan R. and David L. Weimer. 2001. "Criteria for Infrastructure Investment: Normative, Positive, and Prudential Perspectives," in Building the Future: issues in public infrastructure in Canada, Vining and Richards, eds.

Walker, David J. 1960. "What We Are Doing and What You Can Do About Employment," address given on December 1, 1960 to the Empire Club of Canada by the Honourable David J. Walker, Q.C., M.P. Minister of Public Works. http://www.empireclubfoundation.com/details.asp?SpeechID=283\&FT=yes

Wallack, Jessica S and T.N. Srinivasan, eds. 2006. Federalism and Economic Reform International Perspectives. Cambridge: Cambridge University Press).

Webley, Simon. 1985. Stiffening the sinews of the nations: economic infrastructure in the United States, United Kingdom and Canada. London: British-North American Committee.

Wells, Paul. 2003. "Martin Faces an Infrastructure Deficit," Macleans, November 24, 2003.

Wiengast, Barry R. 1994."Reflections on Distributive Politics and Universalism," Political Research Quarterly, Vol. 47, No. 2, 319-327.

Weingast, Barry R., Kenneth A. Shepsle, Christopher Johnson. 1981."The Political Economy of Benefits and Costs: A Neoclassical Approach to Distributive Politics," The Journal of Political Economy, Vol. 89, no.4 (August), pp. 642-664.

Wilkinson, Margaret. 1994. "Paying for Public Spending: Is There a Role for Earmarked Taxes?" Fiscal Studies, Vol. 15, no. 4, pp. 119-35. http:/www.ifs.org.uk/fs/articles/wilkinson nov94.pdf

Wilson, Seymour V. 1983. "Mandarins and kibitzers: men in and around the trenches of political power in Ottawa," Canadian Public Administration, Vol. 26, No. 3, Fall. 446-462.

Winston, Clifford. 2005. "So Many Transit Dollars For So Little Congestion Relief," The Brookings Institution, from the Houston Chronicle, July 22, 2005. http://www.brookings.edu/views/op-ed/winston/20050722.htm 
Wolfe, Jeanne M. 2003. “A national urban policy for Canada? Prospects and challenges," Canadian Journal of Urban Research, Vol. 12, No. 1, Summer. 1-21 2006 "Our Common Past: An Interpretation of Canadian Planning History - Part One," Canadian Institute of Planners website. http://www.cip-icu.ca/English/plancanada/wolfe.htm

Wylie, Peter J. 1996. "Infrastructure and Canadian economic growth 1946-1991," Canadian Journal of Economics, XXIX, Special Issue, April. 